\title{
CONTRIBUȚII LA CUNOAȘTEREA EPOCII ROMANE PE VALEA MUREŞULUI MIJLOCIU. CERCETĂRI ARHEOLOGICE PREVENTIVE ÎN SITUL TĂRTĂRIA II, COM. SĂLIŞTE, JUD. ALBA ${ }^{\prime}$
}

\author{
Mihaela Simion, Decebal Vleja, Radu Petcu, ANdrei Heroiu, \\ Florela VASILESCU, NiCOLAE STOICA
}

\author{
CONTRIBUTION TO THE KNOWLEDGE OF THE ROMAN AGE ALONG THE MIDDLE MURES VALLEY. \\ PREVENTIVE ARCHAEOLOGICAL EXCAVATIONS AT TĂRTĂRIA II (SĀLIŞTE COMMUNE, ALBA COUNTY)
}

The article aims a synthetic presentation of the preliminary results of the preventive archaeological excavations made on Tărtăria II site, Alba county, by a team of the NHMR. A detailed analysis is focused on the discoveries dated to the Roman period, considered in the context of the research stage of a certain part of the middle Mures valley. From an archaeological point of view, the most significant horizon is defined by the presence of a Roman period habitation, with two distinct phases. The first one (dated on the first half of $2^{\text {nd }}$ century AD) was identified in connection with the use of an edifice (E4) and other structures in relation to it. During the second phase (the second half of the $2^{\text {nd }}$ century AD - first half of the $3^{\text {rd }}$ century AD) functioned four edifices (EI, E2, E3, E5), with different locations and orientations compared to the previous phase. On both phases, the edifices were situated inside of an area bordered by a ditch. The analysis of the archaeological situation corroborated with epigraphic and historic arguments entitle us to postulate the existence in here of a villa, in connection with the Roman road from Apulum to Ulpia Traiana Sarmizegetusa. Most probably this was a property of a member of the municipal elite of the province's capital.

KEYWORDS: edificies, villa, Roman road, veterani

CUVINTE CHEIE: edificii, villa, drum roman, veterani

Articolul își propune prezentarea sintetică a rezultatelor preliminare ale cercetării arheologice preventive efectuate în situl Tărtăria II de către un colectiv din cadrul Muzeului Naţional de Istorie a României (MNIR). Sunt analizate descoperirile datate în epoca romană, abordate în contextul stadiului cercetării pentru o porţiune din valea Mureșului mijlociu.

În urma evaluării de teren (diagnosticului arheologic) efectuate de către un colectiv al MNIR, în perioada noiembrie - decembrie 2011, au fost identificate, pe traseul lotului 1 al Autostrăzii Orăștie - Sebeș, 11 situri arheologice. În perimetrul cuprins între km $15+100-15+350$, lucrările de diagnostic atrăgeau atenţia asupra unor structuri datate în epocă romană, fiind astfel delimitat situl de la Tărtăria II. În economia de gestionare a patrimoniului arheologic de pe viitorul traseu al căii de infrastructură rutieră, situl a primit sigla de cercetare Tărtăria II - Situl nr. 8 (PI. III). Potrivit legislaţiei române în vigoare, în faza de cercetare arheologică preventivă, în baza contractului încheiat între MNIR şi SC STRABAG SRL ${ }^{2}$ s-a constituit un colectiv de cercetare, coordonat de Muzeul Naţional de Istorie a României. Colectivul a fost compus din: Mihaela Simion, Decebal Vleja, Nicolae Stoica (MNIR) și Radu Petcu, Andrei Heroiu, Florela Vasilescu.

\footnotetext{
1 Prima parte a studiul de faţă reprezintă un raport preliminar asupra structurilor din epoca romană, rezultatele detaliate ale cercetării urmând a fi publicate monografic. Textul studiului a fost redactat de către Mihaela Simion, iar catalogul selectiv al materialului arheologic de către Decebal Vleja. Desenele materialului arheologic au fost realizate de Simona Movilă, Georgiana Ducman, Andra Samson și Decebal Vleja. La ilustraţie, în afara autorilor, au avut contribuții Viorel Ştefan Georgescu, Florentin Munteanu şi Vlad Rumega, cărora li se adresează caldele noastre mulp̧umiri. Aceleaşi mulţumiri se îndreaptă către colegii de la Secţia Restaurare, Gabriela Dragomir, Alexandru Dozsa, Mihai Duca, Radu Bălănescu şi Mădălina Voicu, care au contribuit la restaurarea cu celeritate a materialului arheologic

2 În conformitate cu legislaţia în vigoare, respectiv Legea nr. 422/2001 privind protejarea monumentelor istorice, republicată [Legea nr. 259/2006, art. 19, paragraf (3), litera a)] şi, respectiv, prevederile Ordonanței nr. $43 / 2000 \mathrm{cu}$ modificările ulterioare (respectiv Legea nr. 258/2006, art. 7).
} 
La cercetări au mai participat şi Răzvan Petcu şi Florentin Munteanu ${ }^{3}$. Cercetarea arheologică preventivă s-a desfăşurat în perioada 9 iulie-18 august 2012.

Din punctul de vedere al formei de relief, zona în care s-a concentrat investigaţia face parte din Culoarul Orăştiei, situat între văile Sebeşului și Streiului. Acesta are lungimea de circa $48 \mathrm{~km}$ și este orientat ENE - VSV. Lăţimea sa creşte treptat spre est, oscilând între 13,50 km (la est de Pianu de Jos) şi 16,50 km (la confluența Mureșului cu Streiul). Altitudinea sa este cuprinsă între $189 \mathrm{~m}$ (la confluenţa Mureşului cu Streiul) şi 593 m (Dealul Măgura) ${ }^{4}$.

În ceea ce priveşte spaţiul unde a fost identificat şi cercetat situl, acesta este amplasat la circa 500 m spre est față de actuala localitate Tartăria ${ }^{5}$, pe un platou ce domină valea Mureșului, asigurându-se o excelentă vizibilitate. Este sesizabilă intervenţia antropică asupra configuraţiei inițiale a terenului, platoul fiind aplatizat ca urmare a nivelării continue a zonei. Nivelarea platoului s-a realizat iniţial pentru amplasarea structurilor de locuire cercetate, iar ulterior prin lucrări agricole succesive. Se păstrează, însă pe direcția N-S, o uşoară pantă ce sugerează configurația iniţială a terenului, fapt demonstrat de analiza stratigrafiei generale a perimetrului cercetat. Astfel, în partea de nord a sitului, nivelul vegetal este mult mai subțire, complexele arheologice fiind identificate la o adâncime de 0,10-0,20 m, față de actualul nivel de călcare (Pl. U/2-3).

De-a lungul vremii zona a fost identificată prin diverse toponime, dintre care amintim „Podul Tărtăriei”. Pe ridicarea topografică cunoscută sub denumirea de Harta Iosefină a Transilvaniei (1769-1773), se observă existența platoului, care domina valea Mureşului, dar şi drumul către Sebeş.

Situl Tărtăria II nu era cunoscut în literatura istorico-arheologică înainte de evaluarea de teren prilejuită de realizarea actualului proiect de infrastructură rutieră ${ }^{6}$. Există însă, o serie de cercetări şi semnalări în bibliografia istorico-arheologică, datorate mai ales vecinătății cu binecunoscutul sit neolitic de la Tărtăria. Astfel, sunt localizate şi introduse în RAN siturile de la Tărtăria „Gura Luncii” (cod RAN 7080.01 - la 0,20 km NE de halta CFR, cu structuri datate în perioada neolitică, eneolitică și epoca bronzului) şi de la Tărtăria „Halta CFR” (cod RAN 7080.02, cu structuri datate în perioada neolitică și eneolitică). Surprinzător, nu există nici o mențiune clară despre prezenţa unor descoperiri certe din epoca romană sau medieval timpurie, ci doar semnalări a unor asemenea descoperiri în teritoriul comunei Sălişte. În repertoriul dedicat așezărilor rurale din Dacia Romană, cercetătorul sibian Dumitu Popa, la vocea Săliştea (jud. Alba), plasează , din aria satului, fără precizări topografice”, descoperirea unor , obiecte mărunte de bronz și o monedă cu legenda PROVINCIA DACIA"7. Potrivit literaturii de specialitate, în 1865, cu prilejul construirii căii ferate a fost descoperită o lespede funerară a unui veteran din Legiunea a V-a Macedonica ${ }^{8}$, decurion al Coloniei Dacica. Monumentul, era pus în legătură cu „resturile unor constructii romane", aflate la limita dintre hotarele satelor Pianul de Sus şi Săliştea.

Aproximativ aceleași informații sunt cuprinse și în Arhiva - Repertoriul Arheologic al României, a Institutului de Arheologie „Vasile Pârvan”, cu specificaţia că sunt legate de satul Cioara (vechiul nume al localității). Fișa de repertoriu conține şi alte semnalări ale unor descoperiri în zonă, fără a face precizări topografice. Astfel, la confluenţa pâraielor Archiş şi Pietroasa, în punctul „Sălişte”, în 1944, săpăturile coordonate de Dumitru Berciu şi Ioan Berciu au pus în evidență o aşezare datată în epoca bronzului, cu câte un nivel aparținând culturilor Coțofeni și Wietenberg. Situl a fost, se pare, distrus de apele Archişului ${ }^{9}$. Din zonă, dar fără precizări topografice, provin o serie de artefacte datate în diferite epoci istorice, dintre care amintim: un topor de granit (cultura Coţofeni), o secure și un vas de bronz (epoca bronzului), mai multe brățări

\footnotetext{
${ }^{3}$ Conform autorizaţiei de cercetare arheologică preventivă nr. 182/17.07.2012, eliberată de Ministerul Culturii.

${ }^{4}$ Mărculet, Mărculeț 2011, 27

5 Satul Tărtăria aparține comunei Săliștea (jud. Alba) fiind situat de-a lungul DJ 705 E şi a drumului comunal care coboară înspre sat, în partea de nord a comunei, la o distanța de 3,50 km de satul Săliștea.

${ }^{6}$ Un istoric al cercetărilor din zonă este disponibil şi la Borş et alii 2013, 15-16, în articolul dedicat cercetărilor preventive din situl de la Tărtăria I, realizate cu ocazia aceluiaşi proiect investiţional.

${ }^{7}$ Popa 2002, nr. 551

${ }^{8}$ Potrivit lecturii propuse în IDR III/3, 278.

${ }^{9}$ Berciu, Berciu 1946-1948, 33-35
} 
de bronz (epoca bronzului), o monedă dacică de tip Filip al II-lea, un denar roman republican, un denar imperial emis în timpul domniei lui Vespasian ${ }^{10}$. Tot din zonă, cu precizarea că se referă la perimetrul dinspre Pianu de Sus (destul de departe de zona investigată de noi), provine un celebru tezaur (tezaurul de la Cioara), din epoca Latène, alcătuit din 64 de obiecte din argint, descoperit în 1821, astăzi păstrat la Kunsthistoriches Museum din Viena ${ }^{11}$. În 1988, cu prilejul unei periegheze în zona așezării neolitice a fost identificat un mormânt de incinerație pe care autorii cercetării îl atribuie, pe baza inventarului, unui „războinic geto-dac" ${ }^{\prime 2}$.

Privitor la inscripția provenită din această zonă (CIL III, $6264=$ IDR III/3, 278) aceasta are textul:
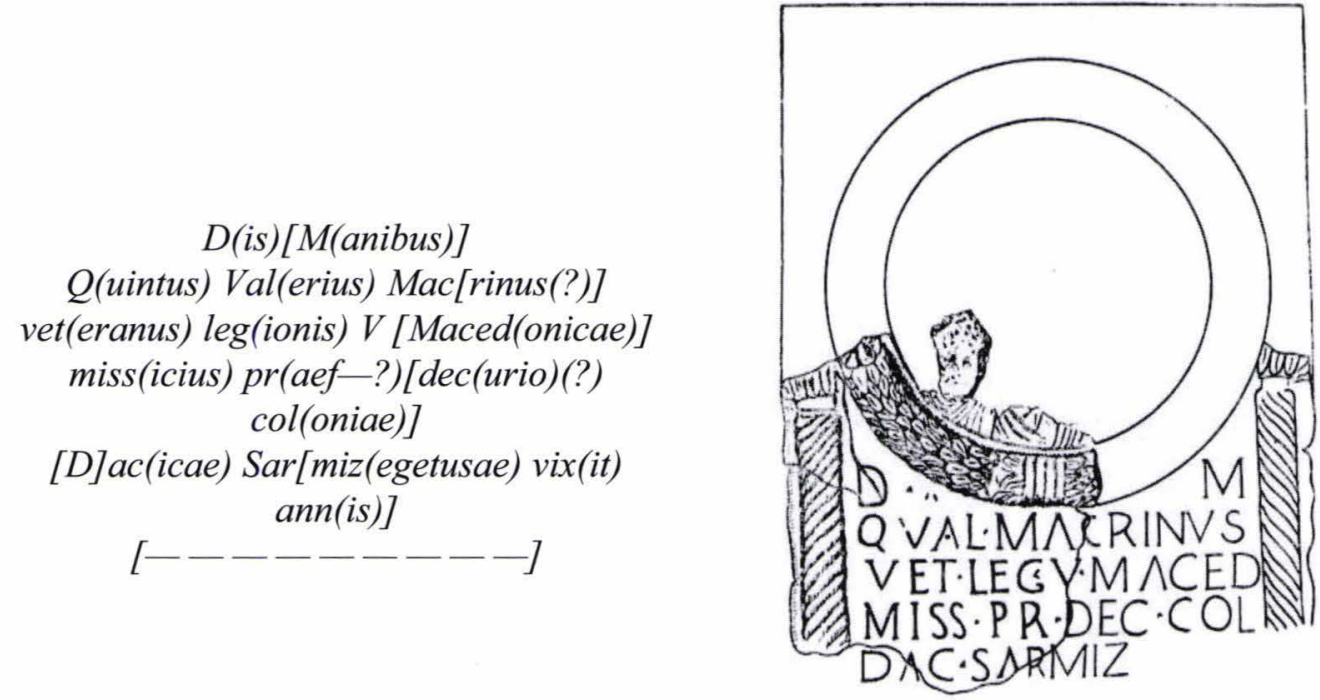

Informațiile cu privire la locul exact al descoperirii plasează zona de proveniență a monumentului (cu ocazia construcției căii ferate) lângă „Hanul numit Valea Rea”13. Pe una dintre hărțile iosefine, în valea pe care se va construi, la 1865 , calea ferată, este figurată, în vecinătatea satului Tărtăria, o astfel de Taverna (Wirthaus), iar zona de localizare a sitului Tărtăria II este identificată prin toponimul „Valea Rea"14.

\section{METODOLOGIA DE CERCETARE}

$\mathrm{Au}$ fost trasate inițial 17 secțiuni, din care ulterior s-au dezvoltat, opt suprafețe de cercetare (PI. III/1). Pentru perimetrele în care au fost identificate complexe arheologice s-a optat pentru decopertarea în suprafață și abordarea tuturor complexelor arheologice potrivit modelelor de bună practică uzuale în arheologia preventivă. Astfel, a fost delimitat un perimetru de aprox. $7780 \mathrm{~m}^{2}$ unde se concentrau complexele arheologice. Au fost utilizate următoarele proceduri arheologice: investigarea exhaustivă a complexelor identificate, realizarea de fişe de secţiune și fișe de complex, înregistrarea situațiilor arheologice prin desene (planuri și profile la scara $1 / 20$ și $1 / 50$ ), fotografierea secţiunilor şi a complexelor identificate, prelucrarea primară a materialului arheologic

\footnotetext{
${ }^{10}$ Cf. A-RAR, sv. Cioara

${ }^{11}$ Cf. A-RAR, sv. Cioara

${ }^{12}$ Ciugudean, Ciugudean 1993, 77-79

${ }^{13}$ IDR III/3, 278

${ }^{14}$ Vezi, de asemenea, analiza izvoarelor topografice și observațiile asupra toponimiei locului la Borș et alii 2013, $12-14$.
} 
recoltat, realizarea de fişe de material arheologic special, procesarea digitală a fișelor şi desenelor arheologice.

$\mathrm{Au}$ fost identificate şi cercetate 36 de complexe arheologice (denumite convenţional cu sigla Cpl.) şi cinci edificii (denumite convenţional cu siglele E1-E5), datate în patru perioade istorice distincte. Atribuirea siglelor complexelor s-a realizat în ordinea conturării acestora.

Pentru stabilirea stratigrafiei generale a perimetrului investigat, pe toată durata cercetării s-au păstrat două profile magistrale, unul orientat N-S şi celălalt E-V. Profilele au fost alese în aşa fel încât să surprindă cât mai mult din relą̧ia existentă între fazele de construcţie ale edificiilor din epoca romană şi restul structurilor identificate în cercetare (PI. III/2).

Pentru axa N-S, situaţia stratigrafică înregistrată este următoarea:

1. strat organic (solul actual), constituit din silt argilos, de culoare brun cenuşie, omogen, cu caracter organic, cu structură agregată şi fisuraţie prismatică, compact, cu o grosime de 0,25 $0,30 \mathrm{~m}$;

2. strat organo-mineral al solului actual, constituit din silt argilos, de culoare brun gălbuie; are în compunere fragmente ceramice, oase de animale; din punct de vedere al interpretării nivelul poate constitui secvenţa de abandon, ulterioară funcţionării edificiilor din epoca romană, în care se amenajează complexele medieval timpurii; partea superioară a acestui nivel a fost afectată de lucrările agricole efectuate în perimetru, în decursul epocilor modernă şi contemporană; nu a fost observat continuu pe întreaga suprafał̧a investigată; grosime $0,10-0,15 \mathrm{~m}$;

3. strat organo-mineral al solului antic, constituit din silt argilos, de culoare brun negricioasă; din punct de vedere stratigrafic, nivelul corespunde perioadei de funcţionare şi eventual, demontare a E4 şi perioadei de construcţie a E1-E3; în componenţa sa sunt vizibile resturile zidurilor E4, reduse la un pat de nisip cu pietriş; în acest nivel se observă cum amenajarea complexului 22 intersectează resturile din zidăria E4, oferindu-ne un raport clar de anterioritateposterioritate; grosime $0,10-0,15 \mathrm{~m}$;

4. strat mineral ce reprezintă materialul parental al solului actual (loess); constituit din silt argilos de culoare gălbuie, omogen, compact, fără urme arheologice.

Pentru axa E-V, situaţia stratigrafică înregistrată este următoarea:

1. strat organic al solului actual; constituit din silt argilos, de culoare brun cenuşie închisă, omogen, cu caracter organic, cu structură agregată şi fisuraţie prismatică, afânat; are în compunere material arheologic divers, de la fragmente ceramice preistorice până la monedă din 1952; grosime $0,07-0,10 \mathrm{~m}$;

2. strat organo-mineral al solului actual; constituit din silt argilos, de culoare brun gălbuie; din acest nivel a fost observată o groapă (complexul 30), cu material datat în secolele XI-XII; este nivelul corespunzător tuturor complexelor post-romane; grosime $0,06-0,12 \mathrm{~m}$;

3. strat organo-mineral al solului antic constituit din silt argilos, de culoare brun negricioasă; are în compunere un strat consisitent de ţigle şi olane, datate în epocă romană, pe toată suprafał̧a corespunzătoare E1; din acest nivel provine un bogat material arheologic, ce aparţine celei de-a doua faze de locuire, datată în epocă romană; partea sa superioară surprinde nivelul de amenajare a complexului $30 \mathrm{~A}$, ceea ce ne sugerează că este vorba despre o fază timpurie, a ocupării spaţiului în perioada medievală (secolele IX-XI ?); grosime $0,10-0,15 \mathrm{~m}$;

4. strat constituit din silt argilos, de culoare brun cenuşie cu pete de culoare gălbuie; partea sa superioară este suprapusă de amenajarea fundaţiilor E1, fiind probabil un nivel de exterior din prima fază a locuirii romane (E4 şi complexul 7); grosime 0,06-0,12 m;

5. strat constituit dintr-un silt argilos, de culoare brun roşcată, cu pete cenuşii, din care a fost recoltat material ceramic fragmentar de factură preistorică (cultura Coţofeni); nivelul este perturbat semnificativ de cel ulterior, nefiind observat continuu; grosime $0,07-0,10 \mathrm{~m}$;

6. strat mineral ce reprezintă materialul parental al solului actual (loess), constituit din silt argilos de culoare gălbuie, omogen, compact, fără urme arheologice.

Datele obținute în urma cercetării arheologice ne îndreptăţesc să afirmăm că perimetrul investigat a fost ocupat de comunităţi umane în patru perioade istorice distincte.

Orizontul nr. 1 - locuire dispersată corespunzătoare culturii Coțofeni, mai precis perioadei de tranziție la epoca bronzului (Pl. IV/1). 
Pentru această epocă au fost identificate și cercetate trei complexe arheologice complexele 2, 25, 28. Este vorba de resturi de locuințe de suprafață, păstrate parțial, grav afectate de amenajările corespunzătoare Orizontului nr. 2. Nivelul corespunzător acestei perioade este discontinuu, fiind vizibile porţiuni pe care este evidenţiat nivelul ocupaţional Coţofeni sau zone cu fragmente ceramice Coţofeni sparte pe loc, posibile resturi de structuri de locuire de suprafaţă, caracteristice sistemului de habitat din zonă ale acestor comunităţi ${ }^{15}$.

Cel de-al doilea orizont (nr. 2), cel mai consistent, din punct de vedere arheologic, este definit de prezența unei locuiri romane, cu două faze distincte de ocupare a spațiului (Pl. IV/1-2).

Faza întâi - un nivel corespunzător epocii romane, legat de funcţionarea unui edificiu (denumit convențional E4). În conexiune stratigrafică cu acest edificiu au mai fost identificate patru alte complexe - complexul 1 (amenajare interioară), 7 (șanț de delimitare/apărare), 6 (șanț de drenaj) și complexul 14 (PI. IV/2, Pl. V/1).

Fazei a doua îi corespund patru edificii $(E 1$, E2, E3, E5) cu o orientare diferită față de faza anterioară. Tot acestui nivel îi corespund şi complexe arheologice 3-5, 12-13, 17-18, 22, 24, 29 și 35 (Pl. IV/2; V/2).

Perioada post-romană şi medieval timpurie corespunde, din punct de vedere al stratigrafiei verticale şi orizontale, Orizontului nr. 3. Se constată și o ocupare parțială a spațiului într-o perioadă nu foarte îndepărtată de momentul abandonării edificiilor romane, în condițiile în care resturile E1 şi E3 sunt încă vizibile. Este vorba de amenajarea, pe nivelul de țiglă prăbuşită din E1 și în interiorul E3, pe pavaj, a unor vetre sezoniere (cenuşă, cărbune, urme de foc).

Orizontul nr. 4 este definit de prezența a zece locuințe rectangulare, de obicei adâncite, cu cuptor tip pietrar, specific perioadei secolelor IX-XII pe valea Mureşului mijlociu (complexele 8, $9,15,20,21,23,30,30 \mathrm{~A}, 31,32$ ). De remarcat faptul că în amenajarea pietrarelor sunt reutilizate materiale de construcție din nivelul roman. Cu prudenţă, opinăm că şi aici par a se contura două faze diferite, una mai timpurie, legată de reutilizarea materialului de construcţie roman şi de aşezarea, în imediata vecinătate, a edificiilor, pentru ca, ulterior, locuirea să se extindă pe întreg platoul (PI. IV/1).

Vom stărui, în rândurile care urmează, asupra structurilor arheologice datate în epoca romană.

Pentru prima fază a ocupării spațiului în epocă romană, principala structură cercetată este reprezentată de edificiul E4. Localizat în $\mathrm{Sp} .5-\mathrm{Sp}$. 3, edificiul are o formă rectangulară, cu dimensiunile de $18,00 \times 17,00 \mathrm{~m}$, cu latura lungă orientată pe axa V-E. Orientarea sa este total diferită față de edificiile E1, E2 și E3, fiind de altfel și suprapus de colțul de sud-vest al edificiului E2, dar şi de un complex ulterior (complexul 22). Edificiul are 4 compartimentări vizibile. Planul edificiului a fost reconstituit pe baza interpretării negativelor zidurilor dezafectate din antichitate și nivelate, pentru construirea fazei a II-a din epoca romană. În afara intervențiilor mai sus menționate, se cuvine amintit faptul că, în interiorul Camerei 1 a fost identificat complexul 1. Acesta este o groapă de formă rectangulară $(2,55 \times 1,45 \mathrm{~m})$, orientată $\mathrm{E}-\mathrm{V}$ cu adâncime maximă surprinsă de $1,10 \mathrm{~m}$. La baza gropii se constată existenf̧a unei aglomerări de piatră de șist friabilă, urma unei amenajări. Pe latura scurtă, vestică şi pe peretele corespunzător se constată prezenţa unui strat de mortar din var, care pare să delimiteze și să căptușească amenajarea. Umplutura gropii este formată dintr-un strat argilos în amestec cu nisip și var, distribuit în mici lentile şi pete, cu pigmenţi de cărbune şi fragmente ceramice. Peste acest prim nivel se constată nivelul de colmatare, reprezentat de un sediment argilos, sfărâmicios, de culoare brun negricioasă. Din umplutură au provenit oase de animale (craniu de bovină mare), fragmente de țigle, cărămizi, olane. Modalitatea de amenajare, poziționarea şi dimensiunile acestei structuri poate indicata o funcționalitate legată de colectarea apei pluviale, iar spațiul în care este amplasată sugerează, în economia clădirii, funcționalitatea de atrium (PI. V/1, PI. VI/2, PI. VII/1, 7/2).

În această fază, clădirea funcționează într-un spațiu delimitat de un șanț de mari dimensiuni (denumit convențional complexul 7), care înconjoară toate complexele din epoca romană din faza 1. A fost surprins cel mai clar pe latura de est şi pe cea de sud, traseul său fiind

\footnotetext{
${ }^{15}$ Pentru întreaga problematică, vezi Popa 2012.
} 
perturbat şi uneori anulat, de amenajarea complexelor din nivelul medieval. Inițial, acesta delimita o suprafață cu dimensiunile $L=$ aprox. $35 / 36 \mathrm{~m}, 1=18 / 20 \mathrm{~m}$, în interiorul căreia se află amplasate edificiul E4 și complexele 6 și 15 . Adâncimea sa este variabilă, în funcție de intervențiile ulterioare asupra configurației terenului, variind între $0,10 \mathrm{~m}$ și $0,70 \mathrm{~m}$. Pe latura de est, structura este întreruptă, probabil pentru amenajarea unei căi de acces în interiorul perimetrului protejat. De asemenea, pe latura de sud, complexul 7 a fost afectat semnificativ de un sondaj geologic efectuat anterior cercetării. Traseul laturii de vest este raportat la funcționarea Edificiului nr. 3, din faza a doua de ocupare a spaţiului din epoca romană. Complexul 7 funcționează fără modificări semnificative şi în această a doua fază (Pl. IV/1-2, PI. V/1-2). Din umplutura sa a provenit o cantitate însemnată de material arheologic, foarte divers, constituit din fragmente ceramice, oase de animale, piese din bronz, piese din fier, fibule, fragmente de sticla, apucătoare de opaiț cu reprezentarea unei acvile, monedă (PI. XIV-XVI).

Un alt şanț, de dimensiuni mai mici $\left[\mathrm{L}_{\text {obsv. }}=12,75 \mathrm{~m} ; 1_{\max }=1,00 \mathrm{~m} ; \operatorname{ad}_{\max .}=0,45 \mathrm{~m}\right]$ a fost identificat în Sp. 1. Complexul a fost cercetat parțial, doar în zona afectată de proiectul autostrăzii. Acesta a primit sigla de Cpl. 6, fiind orientat pe direcția N-S. Limita sa de sud a fost deranjată de amenajarea Edificiului nr. 1 din faza a doua de ocupare a spațiului în epocă romană. Este interesant de remarcat faptul că cel de-al doilea șanț funcționează în acelaşi timp cu complexul 7, fiind amenajat probabil ulterior acestuia, având în vedere faptul că cele două structuri sunt paralele, urmând panta naturală a terasei (complexul 6 este paralel cu latura estică a complexului 7). Din umplutură au provenit fragmente ceramice, oase de animale şi un mâner de os. În ceea ce privește funcționalitatea complexului 6, este vorba, probabil de o amenajare cu rol temporar de colectare şi dirijare către pantă a apei pluviale, în legătură cu structurile și edificiile din faza 1 romană (PI. IV/1-2, Pl. V/1).

Ultimul complex arheologic pentru care, pe baza argumentelor stratigrafice, s-a putut atribui o datare în aceeași fază 1 romană este complexul 14. Este o groapă de formă neregulată cu latura lungă orientată N-S, cu dimensiunile de 3,95 × 2,90 m, trapezoidală în secțiune, ce se adâncește în nivelul de loess cca $0,30 \mathrm{~m}$. Pe fundul gropii s-a constatat prezența unui strat consistent de var amestecat cu nisip, peste care se găsesc pietre de dimensiuni medii, fragmente ceramice, fragmente de material tegular, oase de animale mari. Umplutura complexului este constituită dintr-un sediment compact de culoare brun cenuşie - silt argilos - amestecat cu fragmente ceramice şi fragmente de material tegular, fragmente mici de cărbune şi pete de var nisipos. În partea sa de est, groapa este perturbată de amenajarea complexului 6 , ceea ce ne oferă un important indiciu pentru datarea momentului amenajării complexlui 14. În ceea ce privește funcționalitatea acestui complex, cu prudența de rigoare, putem avansa ipoteza potrivit căreia este o groapă de var sau de preparare a mortarului, corespunzătoarea amenajării edificiului $\mathrm{E} 4$, neexcluzând nici ipoteza unei structuri de locuire ulterior transformate în groapă de var. Inventarul acestui complex constă în fragmente ceramice, material tegular fragmentar, oase de animale (PI. V/1).

Cea de-a doua fază de ocupare a spațiului în perioada romană se caracterizează prin modificarea semnificativă a structurii spațiului delimitat de complexul 7 (şanțul de delimitare). Astfel, edificiul E4 este dezafectat, iar în interiorul perimetrului delimitat de complexul 7 sunt ridicate alte patru edificii distincte (edificiul E1, edificiul E2, edificiul E3 și edificiul E5).

Edificiul E1, localizat în Sp. 1 - Sp. 2, era o clădire de formă rectangulară, cu dimensiunile de $16,25 \times 12,25 \mathrm{~m}$, orientată pe axa NE-SV. Au fost surprinse doar traseele fundației acestui edificiu, realizată din galeți, legați cu pământ. Zidurile sunt într-o stare relativ bună de conservare, permițând reconstituirea fidelă a planului edificiului. Lățimea zidurilor era de $0,70 \mathrm{~m}$. Pe latura de est, în zona centrală, zidul este întrerupt pe o porțiune de $2,75 \mathrm{~m}$, într-o zonă care corespunde cu întreruperea complexului 7 , ceea ce sugerează existența unei intrări pe această latură. Pe latura de sud, în interior, sunt prezente trei structuri de piatră legate cu pământ, țesute cu paramentul interior, cu dimensiuni de cca $1,00 \times 0,70 \mathrm{~m}$. Ele pot avea rol legat atât de compartimentare, cât și de întărire a structurii de rezistență a zidului. În zona de SE, s-a constatat o aglomerare de material tegular provenit din prăbușirea acoperișului (o mare cantitate de țigle și olane). La demontarea acestuia s-a observat că în acea zonă, în exteriorul zidului de sud, edificiul era bordat de o alee amenajată din piatră fasonată și semifasonată (complexul 35). De remarcat faptul că materialul 
tegular este poziționat preponderent în apropierea zidurilor şi foarte puțin în interior, mai ales către latura de sud.

În ceea ce privește modalitatea de realizare a elevației, nu avem alte indicii arheologice decât prezența unei mari cantități de cuie şi scoabe din fier, utilizate, de obicei, pentru îmbinarea materialului lemnos.

Informațiile arheologice necesare pentru reconstituirea planului Edificiului nr. 1 sunt completate de analiza altor cinci complexe $(12,13,17,18$ şi 29) poziţionate paralel cu latura de nord a acestuia. Astfel, complexele 12,13,18 şi 29 sunt amenajări din piatră semifasonată așezată pe un singur rând, având formă rectangulară și dimensiunile de $0,40 \times 0,40 \mathrm{~m}$. S-au evidențiat la adâncimea de $0,50 \mathrm{~m}$ față de nivelul actual de călcare. Distanța dintre ele este de aprox. 3,50-4,00 $\mathrm{m}$, urmând acelaşi aliniament paralel cu latura de nord a edificiului E1. În acelaşi context stratigrafic şi cu aceeași poziționare, trebuie menționat complexului 17 , respectiv o groapă de par cu diametrul de $0,25 \mathrm{~cm}$, evident, făcând parte din aceeași amenajare funcțională.

Toate acestea sugerează faptul că poate fi vorba despre o clădire cu elevație din lemn şi acoperiș de țiglă, care probabil descria o curte interioară, de-a lungul zidurilor fiind amenajate diverse încăperi de mici dimensiuni. Pe latura de nord a edificiului ar fi putut fi amenajat un cerdac deschis (portic) ${ }^{16}$. Acest tip de clădire îşi găsește analogii în edificiile considerate ca făcând parte din ansambluri de tip villa cercetate în Dacia intracarpatică ${ }^{17}$.

Materialul arheologic descoperit în relație cu acest edificiu constă în fragmente ceramice, două monede, o mărgică din sticlă, piese din bronz și fier (număr însemnat de cuie şi piroane, dar şi unelte şi piese de uz comun). În afara materialului datat în epocă romană, din zona de amplasare a edificiului El provine un pinten cu spin medieval, precum şi un fragment de pipă de la începutul secolului al XIX-lea (PI. V/2, VI/1, VIII/1-2, IX/1-2).

Edificiul E2, localizat în suprafața Sp. 1 și secțiunea S. 7, este o clădire de formă dreptunghiulară, orientată pe axa NE-SV, cu dimensiunile de $16,70 \times 9,25 \mathrm{~m}$. Au fost surprinse doar traseele fundației acestui edificiu, realizată din galeți, legați cu pământ, pe un pat de nisip şi pietriş. Zidurile sunt într-o stare precară de conservare, pe Alocuri, reconstituirea planului acestui edificiu fiind realizată doar pe baza interpretării amprentelor acestora. Lățimea zidurilor, în porțiunile prezervate, este de $0,65 / 0,70 \mathrm{~m}$. Edificiul are o orientare similară cu edifíciul El şi edificiul E3, latura sa lungă fiind aliniată cu latura de vest a E1. Se remarcă lipsa materialului tegular în legătură cu această structură, ceea ce indică o soluţie de realizare a acoperişului din materiale perisabile. În interiorul edificiului, la o distanță de cca 2,00 m față de latura de est, au fost identificate amprentele (la nivel de pat de nisip cu pietriş) a patru structuri rectangulare, cu dimensiunile de $1,00 \times 1,00 \mathrm{~m}$, ce fac parte, probabil, din sistemul de compartimentare şi susținere a acoperișului E2, definind mici spații interioare.

De remarcat faptul că amenajarea edificiului E2, suprapune parțial edificiul anterior, din prima fază de ocupare a spațiului, în epocă romană (edificiul E4), iar latura sa de vest este afectată de o intervenție ulterioară (complexul 19). În ceea ce privește modalitatea de realizare a elevației, nu avem alte indicii arheologice decât prezența unei mari cantități de cuie și scoabe din fier, utilizate de obicei, în această epocă, pentru îmbinarea materialului lemnos. Materialul arheologic descoperit aici constă în fragmente ceramice, o fibulă, piese din bronz şi fier, cuie şi piroane din fier, două monede (una antică, iar cealaltă din 1952), unelte din fier. Amenajarea Edificiului nr. 2 a fost realizată într-o manieră diferită față de celelalte două edificii contemporane, lipsind grija pentru detalii și elemente constructive elaborate. Toate acestea sugerează o funcționalitate de anexă şi nu de spațiu de locuit, atrăgând însă atenția suprafața sa de $154,47 \mathrm{~m}^{2}$, puțin plauzibilă în cazul unei anexe gospodărești individuale (PI. V/2, X/1-2, XIII/1).

Edificiul E3, localizat în Sp. 5-Sp. 8, este o clădire de forma rectangulară, cu dimensiunile de $8,20 \times 5,40 \mathrm{~m}$, cu axa lungă orientată pe axa NV-SE. Precizăm faptul că latura scurtă a edificiului are o orientare paralelă cu cele ale edificiilor E1 și E2. Au fost surprinse doar traseele fundației acestui edificiu, realizată din galeți, legați cu pământ. Zidurile sunt într-o stare bună de

\footnotetext{
${ }^{16}$ Avem în vedere o amenajare de tip Laubengang (Veranda), vezi Smith 2002, XXXi (Glossary).

${ }^{17}$ Vezi mai jos discuția referitoare la interpretarea funcţională a ansamblului roman de la Tărtăria II.
} 
conservare, permiţând reconstituirea fidelă a planului edificiului. Lățimea zidurilor este de $0,70 \mathrm{~m}$. Zidăria era foarte îngrijit lucrată. În interiorul edificiului a fost surprins restul unui pavaj, parțial păstrat, din faza de utilizare, din lespezi de piatră fasonată și cărămizi. După demontarea nivelului de interior, sub pavaj, s-a observat că acest edificiu fusese construit pe o nivelare, care suprapunea o suprafață cu nisip şi var din faza anterioară. În această nivelare au fost antrenate şi materiale din faza 1, printre care și o monedă de argint, dar și fragmente de vase preistorice.

În ceea ce privește modalitatea de realizare a acoperișului, cantitatea însemnată de țigle şi olane care acoperea nivelul de pavaj indică o soluție constructivă bazată pe aceste materiale. Pereții clădirii au fost probabil din lemn, similar situaţiei constatate pentru celelalte două edificii contemporane, anume E1 şi E2. Materialul arheologic asociat acestei structuri este divers, amintind aici fragmente ceramice, un ac de bronz, piese din bronz şi fier. Menţionăm faptul că în nivelul anterior funcţionării edificiului au fost descoperite câteva unelte, printre care şi o seceră (PI. V/2, XI/1-2, XIII/1).

În afara celor trei edificii din faza a doua descrise mai sus, la limita de nord a perimetrului afectat de viitorul proiect rutier, au apărut indicii despre prezența unui alt edificiu, denumit convențional Edificiul E5. Este vorba despre un nivel de material tegular prăbuşit pe loc. S-a putut identifica pe o lungime de $8,50 \mathrm{~m}$. Lăţimea surprinsă este de $1,30 \mathrm{~m}$. Au fost înregistrate toate detaliile, s-a curățat şi demontat nivelul, recuperându-se materialul arheologic, restul clădirii urmând să constituie obiectul unor cercetări viitoare. Din datele colectate, considerăm că poate fi vorba despre o clădire cu un plan, dimensiuni şi orientare similare probabil cu Edificiul E3, deci făcând parte din cea de-a doua fază romană de ocupare a terenului. Materialul arheologic provenit de pe nivelul pe care a căzut acoperişul este surprinzător de bogat constând în fragmente ceramice, piese din bronz (PI. V/2, XII/5, XIII/2).

O atenție particulară trebuie oferită unui complex (nr 22), localizat în Sp. 2, Sp. 3, S. 6, a cărui analiză aduce informații importante relative la stratigrafia zonei în perioadă romană. Este vorba despre o groapă de formă rectangulară, cu dimensiunile de $4,10 \times 3,90 \mathrm{~m}$, cu latura lungă orientată aproximativ E-V. A fost observată la adâncimea de $0,22 \mathrm{~m}$ (față de nivelul actual de călcare) și se adâncește în nivelul ulterior, apoi în loess, până la cota de $-0,40 \mathrm{~m}$. Groapa este trapezoidală în secțiune, având două mici trepe pe laterală. Umplutura gropii este constituită dintrun sediment argilos, de culoare intens negricioasă datorită cantității mare de cărbune cenuşă din amestec. Din umplutură a provenit un bogat și variat inventar arheologic (fragmente ceramice, oase de animale, fragmente de țigle, olane, piese din bronz şi din fier, o verigă din bronz, mărgica din sticlă, o cheie din fier, un vârf de săgeată, cuie, piroane, scoabe, fragmente de terra sigillata, un opaiț). Stratigrafic se impune precizarea că amenajarea sa a perforat nivelul de funcționare a edificiului E4, demontând o porțiune din zidul perimetral de est al acestuia, funcționalitatea sa fiind legată de faza a 2-a (Pl. XII/1).

Complexul 5, localizat în Sp. 1, este o groapă de formă circulară, cu diametrul maxim de $0,90 \mathrm{~m}$, albiată în secțiune, ce se adâncește în nivelul de loess aproximativ $0,15 \mathrm{~m}$. A fost identificată la cota de $-0,11 \mathrm{~m}$, față de actualul nivel de călcare. Umplutura complexului 5 este constituită dintr-un silt argilos, compactat, de culoare maroniu gălbuie, cu fragmente de material tegular, pigmentație de cărbune și lentile de argilă negricios-cenușie. Ca inventar se remarcă o plăcuță de bronz și fragmente ceramice datate în epoca romană.

Complexul 10, localizat în Sp. 4, reprezintă o structură formată dintr-o groapă de formă rectangulară, orientată $\mathrm{V}-\mathrm{E}$ şi o groapă de par. Dimensiunile sale sunt de $3,10 \times 2,00 \mathrm{~m}$; este albiatã în secțiune și se adâncește în nivelul de loess aprox. $0,40 \mathrm{~m}$. Umplutura este constituită dintrun sediment de culoare brun maronie amestecat cu fragmente ceramice şi fragmente de material tegular. În exteriorul complexului, pe latura de nord, la o distanță de circa $0,50 \mathrm{~m}$ față de aceasta, a fost evidențiată o groapă de par, cu diametrul $0,22 \mathrm{~m}$. Materialul arheologic constă în fragmente ceramice, material tegular fragmentar, obiecte de bronz şi fier, un topor de piatră (PI. XII/3).

Complexul 24, localizat în Sp.1 este o groapă de formă relativ circulară, cu diametrul de 4,50 m. A fost identificată la cota de $-0,25 \mathrm{~m}$ (față de nivelul actual de călcare) și se adâncește în loess, până la cota de $-0,80 \mathrm{~m}$. Groapa este trapezoidală în secțiune şi pare a avea o treaptă pe jumătatea de est. Umplutura gropii s-a realizat în două faze. Prima, cea mai târzie, conține 
fragmente ceramice, fragmente osteologice, material tegular fragmentar, pietre, pigmenți de chirpici ars etc. Cea de a doua conține lentile de lut galben (posibil lutuială de pereți) și o lentilă continuă de cenuşă pe fundul gropii. Sedimentul de umplutură este extrem de pigmentat cu cărbune şi cenuşă. Din umplutură a provenit un bogat și variat inventar arheologic constând în fragmente ceramice, oase de animale, fragmente de țigle, olane și cărămizi, o monedă, ace din bronz, o fibulă din bronz, piese din bronz şi fier, sticlă, lamă cuțit, cheie de fier, o fibulă din fier, o balama din fier, fragmente de unelte din fier, o fusaiolă, fragmente de terra sigillata, un mâner de os etc. (PI. XII/2).

O situație similară a fost înregistrată și în cazul complexului 27, localizat în Sp. 2. Este o groapă de formă rectangulară, cu colțurile rotunjite şi dimensiunile de $4,00 \times 3,30 \mathrm{~m}$. A fost identificată la cota de $-0,70 \mathrm{~m}$ (față de nivelul actual de călcare) și se adâncește în loess, până la cota de $-0,80 \mathrm{~m}$. Baza gropii este dreaptă. A fost surprinsă doar partea inferioară a complexului. Umplutura gropii era constituită dintr-un sediment argilos, de culoare intens negricioasă datorită cantității mari de cărbune cenuşă din amestec. Din umplutură a provenit un inventar arheologic semnificativ, constând în fragmente ceramice, piese din bronz şi fier, cataramă de bronz.

Complexul 3, localizat în SP 2, este o groapă, de formă relativ rectangulară $(2,75 \times 2,90$ $\mathrm{m})$, albiată în secțiune, ce se adâncește în nivelul de loess cca $0,15 \mathrm{~m}$. A fost identificată la cota de $-0,63$ m față de actualul nivel de călcare. Umplutura gropii era constituită din sediment argilos, de culoare gri închisă, probabil în amestec cu cenușă. Este puternic pigmentată cu cărbune și are în compunere fragmente mărunte de ceramică, obiecte din fier, un fragment de teracotă și material tegular (PI. X, XII, XVI, XXIII/2).

Complexul 4, localizat în Sp. 8, este o groapă, de formă rectangulară, orientată N-S, cu dimensiunile de $2,40 \times 2,10 \mathrm{~m}$, albiată în secțiune, ce se adâncește în nivelul de loess circa $0,20 \mathrm{~m}$. În profil, dar și în grund, pe latura de sud, este vizibilă o perturbare stratigrafică (groapă cu diametrul de $0,25 \mathrm{~m}$ ), posibil urma unui par. Pe marginea acestei perturbări se constă prezența unor lentile de var în amestec cu nisip. Umplutura complexului este constituită dintr-un sediment de culoare brun maronie - silt argilos - amestecat cu fragmente ceramice mărunte și fragmente de material tegular. Materialul arheologic constă în fragmente ceramice romane, precum şi material tegular fragmentar. Umplutura perturbării stratigrafice este ușor diferită ca pigmentație față de cea a complexului propriu-zis, fiind constituită din argilă negricioasă, uşor mai afânată, cu lentile de var nisipos şi fragmente de material tegular.

\section{SCURTE CONSIDERATII ASUPRA MATERIALULUI ARHEOLOGIC}

\section{CERAMICA}

Pentru epoca romană materialul ceramic se încadrează în mare parte, în categoria comună, de factură locală. Ceramica rezultată din interiorul edificiilor E1-E3 se caracterizează printr-o diversitate a formelor comune: farfurii, boluri, străchini, oale, capace, ulcioare, căni. Tot din interiorul edificiilor, dar și din complexele 1, 7, 22, 24 şi 27 au fost recoltate fragmente de amfore sau recipiente apropiate ca aspect (amforete). Se remarcă o cană cu trei toarte (nr. cat. 12), descoperită în exteriorul zidului de est al E2. O categorie aparte o reprezintă ceramica de tip terra sigillata. Cea mai mare parte a ceramicii terra sigillata a fost descoperită în complexul 22 (bol cu ștampila MARCIANUS - nr. cat. 2) și în complexul 24 (castron cu ștampila CELSTANIMA - nr. cat. 1), iar un fragment provine din șanțul de delimitare (complexul 7). Vasele au ca motive decorative reptile şi păsări (PI. XIV/1-2).

Spre deosebire de alte structuri din epoca romană cercetate în provincia Dacia, în cazul sitului de la Tărtăria 2, se remarcă ponderea redusă a obiectelor de iluminat. Astfel, au fost descoperite doar trei piese de acest fel, unul în complexul 22 (opaiț reîntregibil de tip Loesche $\mathrm{X}$ nr. cat. 15), în complexul 24 fragmente de opaiț, iar din complexul 7 provine o apucătoare de opait 
cu reprezentarea unei acvile (nr. cat. 16). O piesă deosebită a fost descoperită în complexul 3, respectiv un fragment de teracotă, reprezentând un cap de copil (nr. cat. 17).

\section{OBIECTE DE METAL}

Din complexele datate în epocă romană au provenit şi un număr relativ apreciabil de piese de metal. Dintre acestea se evidențiază, ca artefacte cu putere de datare, şapte monede (bronz şi argint) şi şapte fibule (bronz şi fier, nr. cat. 21-27). Piesele din fier prezentau o stare avansată de oxidare, ceea ce a făcut destul de dificilă identificarea funcţionalităţii lor în stadiul preliminar de cercetare. Obiectele sunt destul de diverse, de la elemente de construcție (cuie, piroane, scoabe, elemente de îmbinare, balamale), până la obiectele de uz curent, piese de port şi piese de armament (verigi, un lanț, chei, lame de cuțit - nr. cat. 40-42, o seceră - nr. cat. 45, un fier de plug - nr. cat. 44 , două vârfuri de săgeată) cu analogii în provincia Dacia $^{18}$.

Relativ numeroase sunt și obiectele din bronz, marea majoritatea fiind datate în epoca romană. Ca şi în cazul obiectelor din fier, se constată o diversitate a acestora (fibule, limbă de curea, cataramă cu carabinieră, trei ace, dintre care unul cu cap în formă de con de pin, verigi, buton de casetă, placă circulară perforată în mijloc etc. -nr. cat. 28-34).

Dintre cele şapte fibule, cinci provin dintr-un context arheologic bine definit, din complexe sau din interiorul structurilor de locuire, iar una a fost descoperită la decapare, fără a putea fi atribuită unui complex arheologic. Având în vedere că această categorie de artefacte arheologice poate oferi importante indicii cronologice vom insista, în cadrul lucrării de fată, asupra analizei preliminare a acestora. Piesele sunt într-o stare satisfăcătoare de conservare, având totuși un stadiu de corodare destul de avansat. Cea mai timpurie piesă provine din şanţul de delimitare al structurilor de locuire (complexul 7). Se încadrează în grupa fibulelor de tip Latène târziu, tip Cociş $3 a^{19}$. Fibula este confecționată din bronz, resortul este bilateral, corpul este de formă circulară în secțiune, iar portagrafa este trapezoidală. Zona lor de maximă răspândire este limes-ul germanoraetic și provinciile vestice ale Imperiului. În Dacia se cunosc șase exemplare, toate descoperite la sud de Mureş, în castre sau niveluri de construcții civile la care au participat şi militari, datate cronologic în perioada împăratului Traian ${ }^{20}$.

Din acelaşi context stratigrafic provine o altă fibulă din bronz, încadrată în grupa fibulelor cu piciorul întors pe dedesubt, tip Cociş $37 \mathrm{a} 5 \mathrm{a} 2^{21}$. Sistemul de închidere este prin resort, iar corpul este arcuit, de formă dreptunghiulară. Aria de răspândire cuprinde în special Dacia, dar se întâlnesc destul de rar şi în alte provincii sau în lumea barbară. În ceea ce privește datarea, Gheorghe Diaconu le încadrează în perioada $160-250$ p. Chr $^{22}$, iar Kurt Horedt în secolul al III-lea p. Chr. ${ }^{23}$

Așadar, descoperirea celor două fibule, situate pe un palier cronologic destul de amplu, ar putea confirma folosirea șanțului pentru structurile de locuire din ambele faze, lucru sugerat și de analiza situației arheologice din interiorul perimetrului delimitat complexul 7.

Tot în categoria fibulelor cu piciorul întors pe dedesubt se încadrează şi cea descoperită în edificiul E3 (Sp. 3, adâncime $0,30 \mathrm{~m}$ ), confecționată din fier, de această dată.

În complexul 24 au fost descoperite două fibule din fier și una din bronz. Fibula din fier se încadrează în grupa fibulelor „Alesia târzii”, tipul Cociș $13 \mathrm{~b} 2^{24}$. Fibula are corpul de formă triunghiulară, sistemul de închidere este cu balama, iar portagrafa este de formă trapezoidală. Aria de răspândire cuprinde nordul Italiei, Pannonia Inferior, Moesia Superior și Dacia, unde sunt

\footnotetext{
${ }^{18}$ Alicu et alii 1994; Gudea 2009, 256-263

${ }^{19}$ Cociș 2004, 39; 255, pl. I/4

${ }^{20}$ Cociș 2004, 40

${ }^{21}$ Cociș 2004, 144; 390, pl. CXXXVI/1889

${ }^{22}$ Diaconu 1971, 248

${ }^{23}$ Horedt 1978, 222

${ }^{24}$ Cociș 2004, 76; 298, pl. XLIV/653-656
} 
răspândite mai ales în partea sudică. După contextele în care au fost descoperite, piesele pot fi încadrate în secolul al II-lea p. Chr.

Fibula din bronz este prevăzută cu balama, are corpul semicircular, iar piciorul, scurt, se termină într-un buton. Se încadrează în tipul Aucissa, tip Cociş $14 \mathrm{~d}_{4} \mathrm{a}^{25}$. Tipul $14 \mathrm{~d}$ este răspândit în Dacia, Moesia Inferior și Moesia Superior. Acest tip apare în a doua jumătate a secolului al II-lea şi continuă în primele decenii ale secolului al III-lea p. Chr.

Din interiorul edificiului E2, dar dintr-un context stratigrafic anterior funcţionării acestuia, provine o fibula din bronz încadrată în tipul fibulelor puternic profilate, tipul Cociş $8 \mathrm{a} 8 \mathrm{~b} 2 \mathrm{a}^{26}$. Piesa are resortul alcătuit din opt spire, pe corp este prevăzută o nodozitate aplatizată, piciorul (de formă triunghiulară în secțiune), se termină într-un buton, are o portagrafa, iar formă trapezoidală. Aria de răspândire cuprinde Noricum, Pannonia, Moesia și Dacia ${ }^{27}$. Dacă inițial au fost încadrate în perioada Hadrian - Marcus Aurelius, datările mai noi propun o perioadă de început în epoca lui Traian $^{28}$.

În fine, din suprafața Sp. 3, provine ultima fibulă prezentată aici, încadrată în tipul fibulelor Omega, tipul Cociș 28a $1^{29}$. Corpul fibulei are forma literei omega, iar sistemul de închidere este prin balama. Este realizată din fier. Aria de răspândire cuprinde întreg Imperiul, iar datarea este foarte largă, secolele I-III p. Chr. ${ }^{30}$ În Dacia nu există nici o piesă databilă mai devreme de mijlocul secolului al II-lea şi sunt răspândite în special în Dacia Superior.

$\mathrm{Au}$ mai fost descoperite două fragmente provenind foarte probabil de la alte fibule: patru spire dintr-un resort și un fragment din corpul alteia, de formă circulară în secţiune.

Obiectele de plumb sunt mai puţin numeroase şi este vorba despre fragmente de placă contorsionate şi un fragment dint-un obiect circular, cu decor sub forma unor raze, având pe verso o agăţătoare, probabil un fragment dintr-o ramă de oglindă (nr. cat. 35).

MONEDELE (nr. cat. 46-52)

$\mathrm{Au}$ fost identificate ${ }^{31}$ emisiuni monetare din următoarele perioade: Traian (anul $100 \mathrm{p}$. Chr.) ${ }^{32}$, Iulia Domna (anii 196-211 p. Chr.) ${ }^{33}$, Caracalla (anul 214 p. Chr.) ${ }^{34}$, Gordian al III-lea (anii

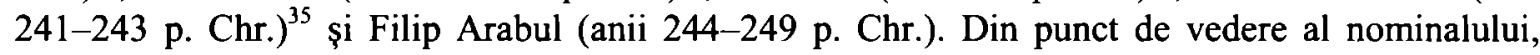
primele trei sunt denari, iar ultimele două, sesterți. Cu excepția exemplarului bătut pentru Filip Arabul, cu legenda Provincia Dacia, la Viminacium, toate celelalte sunt emise la Roma. Alte două monede urmează a fi curățate, însă, după aspectul general (bronzuri de modul mare), ele pot fi încadrate în secolele II-III p. Chr. În ceea ce priveşte locul descoperirii, şase piese provin dintr-un context stratigrafic clar. Astfel, cercetarea edificiului E1 a oferit două monede (Iulia Domna, Filip Arabul), a edificiului nr. 2 o monedă (Gordian al III-lea), iar în interiorul complexelor 7 şi 24 au fost descoperite cele două exemplare ilizibile, dintre care cel ce provine din complexul 24 pare a fi Iulia Domna. Cea mai timpurie monedă (denar emis de Traian), provine dintr-un context stratigrafic anterior amenajării edificiului E3.

\footnotetext{
${ }^{25}$ Cociş 2004, 82, 304, pl. L/750

${ }^{26}$ Cociş 2004, 56; 269, pl. XV/208

${ }^{27}$ Cociș 2004, 56

${ }^{28}$ Gugl 1995, 16

${ }^{29}$ Cociş 2004, 130; 366, pl. CXII/1574

${ }^{30}$ Feugère $1985,419-421$

${ }^{31}$ Identificarea monedelor a fost realizată de Dan Vasilescu.

32 RIC II, 247, nr. 33

${ }^{33}$ RIC IV (1), 170, nr. 577

${ }^{34}$ RIC IV (1), 246, nr. 240

${ }^{35}$ RIC IV (3), 48, nr. 304 (a)
} 
Reprezentative, pentru această categorie de material, sunt fragmente de recipiente din sticlă descoperite în complexul 24 şi în şanțul de delimitare (complexul 7) şi de mărgele din sticlă din interiorul edificiilor E1 şi E2, dar şi în complexul 22. Tot din acest complex provine un fragment de mâner din os.

\section{PROBLEME DE CRONOLOGIE ŞI DE FUNCȚIONALITATE ALE STRUCTURILOR DE EPOCĂ ROMANĂ}

Analiza situației arheologice, coroborată cu datele oferite de cercetarea materialului arheologic, ne permite formularea unei ipoteze de lucru în care distingem două faze de utilizare a spațiului. Pentru faza 1 putem vorbii despre o clădire (edificiul E4) cu anexe şi amenajări (complexele 6 şi 14), delimitate de un şanț perimetral (complexul 7). Reconstituirea planului acestei faze de funcționare este incompletă, având în vedere faptul că limita de nord a platoului nu a fost investigată. De asemenea, primul nivel corespunzător epocii romane a fost semnificativ afectat de transformările și amenajările din cea de-a doua fază. Cu toate acestea, cu privire la funcționalitatea și cronologia acesteia se pot face o serie de considerații.

O situație similară celei înregistrate pentru edificiul E4 este cea constatată în cazul unei villa cercetate la începutul secolului al XIX-lea la Dezmir ${ }^{36}$ (jud. Cluj). Autorii cercetării descriu, printre elementele constitutive ale acestui ansamblu ${ }^{37}$, o clădire cu dimensiunile de $22,25 \times 16,70 \mathrm{~m}$ şi cu ziduri construite în tehnica „opus incertum”. Interesant de remarcat este faptul că în spațiul considerat a fi atrium, autorii cercetării semnalează prezența unei amenjări similare complexului 1 din cadrul sitului de la Tărtăria II, căreia îi atribuie funcționalitatea de ,impluvium”. În cazul unei villa cercetate parțial la Gârbou ${ }^{38}$ (jud. Sălaj) se sugerează că dintr-un astfel de bazin ar fi fost alimentat un canal cu un traseu ce traversează coridorul median al construcției semnalate aici.

Planul clădiri edificiului E4 se înscrie în categoria edificiilor simple, derivate din tipul de construcție cu un coridor transversal la care se aliniază restul încăperilor (trei, în cazul de față), specifice secolului al II-lea p. Chr. ${ }^{39}$ Dat fiind caracterul parțial al cercetării (în sensul că nu putem oferi o imagine a întregului perimetru delimitat de complexul 7), nu excludem ca pentru faza 1 edificiul E4 să fi fost însoțit și de alte dependințe, poziționate în zona necercetată. În orice caz, din perspectiva tipologiei propuse de Joachim Henning, pentru faza 1 credem că ne aflăm în fața unui ansamblu încadrabil în tipul Henning $C^{40}$, eventual $B^{41}$.

Putem însă avansa ipoteza că edificiului E4 i se poate atribui funcționalitatea de locuință a proprietarilor. Acesta acoperă o suprafață de aprox. $306 \mathrm{~m}^{2}$, făă a lua în considerare și alte elemente constructive, dezafectate de construcțiile din faza a doua, astfel încât îl putem compara cu alte edificii cu funcționalitate similară din cadrul ansamblurilor considerate villa cercetate la: Aiud

${ }^{36}$ Vezi în acest sens Popa 2002, nr. 240.

${ }^{37}$ Cercetată în 1903, în punctul „Sub Berc”. Clădirea principală are cinci încăperi și o posibilă curte interioară (atrium). Materialul arheologic provenit de aici constă în cărămizi, tigle, cuie, piroane, o verigă din fier şi ceramică romană. Vezi Mitrofan 1973, 150.

${ }^{38}$ Cercetarea obiectivului, la începutul secolului XX, este însă parțială, iar autorii interpretărilor rezultatelor nu sunt foarte specifici in detalierea caracteristicilor constructive relativ la acest aspect. Astfel, în descrierea rezultatelor cercetării prezentă la Mitrofan $(1973,140)$ este descris un canal „Din atrium pleca de-a lungul coridorului, pe sub acesta, un canal pietruit, larg de $0,35-0,40 \mathrm{~m}$ si adânc de $1 \mathrm{~m}$, si iesea pe sub coltul vetic al încăperii cu absidă, afară. în pantă”. În partea a două a studiului citat (Mitrofan 1974, 51), se specifică textual prezența unui impluvium, însă fără alte detalii.

${ }^{39}$ Vezi în acest sens tipologia propusă de Richmond 1969, 49-70, precum și Bâltâc 2011, 139. De asemenea, vezi Thomas 1964, 162, Abb. 177, unde unul dintre planurile propuse pentru tipul de villa cu Mittelkorridor este aproape similar cu cel al edificiului analizat.

${ }^{40}$ Henning 1987, 27

${ }^{41}$ Henning 1987, 26. De asemenea, vezi analiza făcută acestui tip de ansamblu, cu dependințe separate de casa de locuit, poziționate în interiorul unei curţi la Crova 1942, cap. 5. 
$\left(357,14 \mathrm{~m}^{2}\right)^{42}$, Apahida $\left(369,60 \mathrm{~m}^{2} .\right)^{43}$, Apoldul de Sus - Curtea Velii $\left(384 \mathrm{~m}^{2}\right)^{44}$, Cinciș $(351,85$ $\left.\mathrm{m}^{2}\right)^{45}$ și Sîntămăria Orlea $\left(347,60 \mathrm{~m}^{2}\right)^{46}$. O descoperire din anul 2008 de la Chinteni - Lomb (jud. Cluj), considerată de către autorii cercetării ca fiind o villa, prezintă un plan asemănător, ca structură şi dimensiuni, cu edificiul $E 4^{47}$. Este vorba, aşadar, despre o gospodărie semnificativă, dacă luăm în considerare dimensiunile clădirii principale, dar și suprafața descrisă de structura de delimitare (complexul 7), în care sunt prezente şi urmele celorlalte amenajări corespunzătoare acestei faze.

Chiar dacă datele arheologice înregistrate pentru această fază de funcționare sunt limitate, iar majoritatea uneltelor agricole descoperite pe parcursul cercetării provin dintr-un context stratigrafic în legătură cu funcționarea edificiului E4, considerăm că avem de-a face cu o structură cu caracter agricol. Este greu de distins, având în vedere condiționările obiective impuse de limitele cercetării, dacă avem de-a face cu o simplă fermă de subzistență sau este despre entitate de producție specializată.

În ceea ce privește propunerea de încadrare cronologică, sunt de luat în considerație prezența a trei artefacte cu putere de datare, precum și o serie de informații cu privire la descoperirile întâmplătoare din vecinătate. Astfel, dintr-un context stratigrafic corespunzător funcționării edificiului E4 sunt de amintit un denar, emis în anul 100 p. Chr. (fără urme putemice de rulare), precum și o fibulă de fier, tip Cociș $8 \mathrm{a} 8 \mathrm{~b} 2 \mathrm{a}$, cu aceeași încadrare cronologică timpurie. La aceasta se adaugă semnalarea, în complexul 24, a unei fibule din grupa fibulelor Alesia târzii, tip Cociş 13b2, cu o circulație care indică secolul al II-lea p. Chr. La aceasta se adaugă semnalarea, ca descoperire întâmplătoare, în $z^{-48}{ }^{48}$, a unei monede emise în timpul domniei lui Aelius Hadrianus $^{49}$.

$\mathrm{Cu}$ prudenţa se poate postula o datare timpurie a fazei 1 (edificiul E4, complexele 6, 7 și 14) în prima jumătate a secolului al II-lea $\mathrm{p}$. Chr. Nu avem nici un indiciu privind identitatea ocupanților acestei prime faze, ci doar ipoteza că ne aflăm în fața unei exploatații agricole timpurii, constituită în primii ani ai stăpânirii romane din $\operatorname{Dacia}^{50}$.

Cea de-a doua fază se manifestă printr-o schimbare structurală majoră. Nu se păstrează decât structura de delimitare. În interior se aplică alte reguli de amenajare a spațiului. Este un efort constructiv considerabil, care presupune o putere financiară pe măsură. Astfel, edificiul E4 nu mai funcționează, iar în spațiul delimitat de complexul 7 sunt construite alte, cel puțin patru, edificii și o serie de noi amenajări, cu orientări şi dispuneri care nu au nici un element comun cu faza anterioară. Cele trei clădiri cercetate integral sunt structuri de sine stătătoare, separate. Nici una dintre ele nu prezintă indicii relative la un sistem de încălzire şi nici elemente care să fie legate de asigurarea unui minim confort necesar atribuirii funcţionalității de reşedință a proprietarului. Două dintre ele, edificiul E1 şi edificiul E2, sunt clădiri cu suprafețe generoase $\left(200 \mathrm{~m}^{2}\right.$. și $\left.151 \mathrm{~m}^{2}\right)$, construite pe fundații de piatră, cu pereți de lemn. Edificiul E1 a avut acoperiş de țiglărie, iar edificiul E2 probabil acoperiş din material perisabil (lemn, stuf, paie). De asemenea, se remarcă, în analiza distribuției materialului arheologic, raritatea elementelor ce pot fi puse în legătură cu funcționalitatea de structură de locuire (ceramică, elemente de iluminat, obiecte de port și podoabă). Toate acestea ne îndreptățesc să sugerăm că acestea ar fi putut face parte din zona

${ }^{42}$ Winkler et alii 1968, 59-85; Mitrofan 1973, 128-130

${ }^{43}$ Mitrofan 1973, 130-133

${ }^{44}$ Branga 1986, 145-164, 146, pl. 24; Popa 2002, nr. 30/2

${ }^{45}$ Floca, Valea 1965, 163-192; TIR L 34, 47; Popa 2002, nr. 166

${ }^{46}$ TIR L 34, 103; Tudor 1968, 109; Mitrofan 1973, 148; Popa 2002, nr. 576/1; Gudea 2009, 310

${ }^{47}$ Cercetarea este de asemenea parțială. Edificiul investigat se află într-o stare precară de conservare, elementele sale indicând însă o structură ușor mai elaborată față de Edificiul E4 de la Tărtăria - Cociş et alii 2010, 565-574. În apropiere a mai fost cercetat un ansamblu de tip villa (Alicu et alii 1995, 619-633), prezența acestor structuri fiind explicabilă în relaţie cu poziţionarea zonei în imediata vecinătate a oraşului Napoca şi prezenţa unui drum.

48 Informațiile despre o prezență romană în zonă sunt extrem de sărace şi ambigue, atât în ceea ce privește consistența acestora, cât mai ales localizarea lor. În general, se face trimitere la toponimul Cioara, utilizat generic, atât pentru actuala zonă a satului Sălişte, cât și pentru ceea ce reprezintă teritoriul comunei actuale Sălişte, ceea ce produce dificultăţi în demersul de sintetizare a informaţiei.

${ }^{49}$ Gudea 2009, 262

${ }^{50}$ Vezi în acest sens Paki 1995, 19-37; Benea 2002, 101-102; Piso 2008, 297-331. 
considerată pars rustica sau fructuaria ${ }^{51}$, fiind dependințe de tip depozit/hambar (cella, horreum) sau grajd/spaţiu pentru atelaje (stabulum, tecta $)^{52}$. Pentru această funcţionalitate pledează şi poziţia lor, periferică în economia suprafeței delimitate de complexul 7 , cele două edificii fiind grupate pe limita de sud a ansamblului descris de şanţul de delimitare.

În provincia Dacia, astfel de clădiri, cu caracteristici constructive şi dimensiuni asemănătoare au fost semnalate la Hobița - Grădiște (Clădirea B) ${ }^{53}$, Apoldul de Sus - Curtea Velii $(\text { Clădirea B })^{54}$, Apoldul de Sus - Levejoare (Clădirea B $)^{55}$ şi, recent, la Balomiru de Câmp ${ }^{56}$.

Potrivit observaţiilor noastre, edificiul E3 se află pe latura de vest a curţii delimitate de complexul 7, fiind în conexiune directă cu acesta, găsindu-şi analogii în situațiile constatate la Ciumăfaia $^{57}$, Hobița - Grădiște (Clădirea C $)^{58}$, Deva ${ }^{59}$, Apoldul de Sus - Levejoare ${ }^{60}$, Apoldul de Sus Curtea Velii (Clădirea C) ${ }^{61}$, Miercurea Sibiului - Coşcane ${ }^{62}$. Pentru toate punctele menţionate cercetarea a pus în evidență astfel de structuri, considerate de autorii respectivi ca având funcționalitate de turn de supraveghere a împrejurimilor, uneori combinată și cu aceea de locuință a administratorului domeniului (vilicus), separată de cea principală, a proprietarului ${ }^{63}$. În cazurile de la Ciumăfaia ${ }^{64}$ și Aiud $^{65}$ astfel de $^{6}$ structuri delimitate şi pavate sunt considerate ca fiind mici capele ${ }^{66}$.

Ceea ce diferenţiază situl de la Tărtăria II de toate celelalte structuri considerate villa cercetate şi publicate în literatura de specialitate din Dacia intracarpatică este prezenţa, în interiorul perimetrului delimitat de complexul 7 , a unor posibile locuințe cu podeaua ușor îngropată, care funcționează după prima fază, fiind în legătură cu structurile de zidărie cercetate pentru faza a doua. Acestea au dimensiuni generoase $(4,10 \times 3,90 \mathrm{~m}, 4,00 \times 3,30 \mathrm{~m}, 3,10 \times 2,00 \mathrm{~m})$, elemente care atestă amenajarea ca structuri de locuire (urme de pereţi - complexul 24, posibile podele complexul 14, gropi de par - complexele 10 şi 4). Din acestea provine un bogat şi variat material arheologic care sugerează o funcţionalitate „domestică”. Astfel de locuințe nu sunt necunoscute în peisajul istorico-arheologic al Daciei, fiind însă descoperite în contexte legate de așezări rurale ${ }^{67}$, cu o componentă, mai mult sau mai puţin justificată, a elementului autohton ${ }^{68}$. Este cazul complexelor investigate în cuprinsul siturilor de la Vermeș ${ }^{69}$, Grădinari ${ }^{70}$, Dedrad ${ }^{71}$, $\operatorname{Hodoni}^{72}$,

${ }^{51}$ Potrivit definiţiilor şi recomandărilor „agronomilor” antici, vezi în acest sens DA, s.v. villa, RE, VIII A2, 1958, 2142 2159. De asemenea, cu privire la evoluţia noţiunii de villa și relativ la nuanţele semantice în cadrul textelor antice, vezi Baumann 1983, 14-17 şi Bâltâc 2011, 138-140.

${ }^{52}$ Baumann 1983, 17

${ }^{53}$ TIR L 34, 65; Floca 1953, 743-754: Mitrofan 1973, 142-144; Popa 2002, nr. 320; Gudea 2009, 225, Abb. 33, 309

${ }^{54}$ Branga 1986, 145-164, 146, pl. 24; Popa 2002, nr. 30/2; Gudea 2009, 228 (Abb. 36/1), 308

${ }^{55}$ Branga 1978, 88-97; Branga 1980, 164-186; Gudea 2009, 229 (Abb 37), 308

${ }^{56}$ Dumitraşcu, Raţiu, Dolea 2013, 103-140. Autorii cercetării atribuie clădirii investigate funcţionalitatea de dependintăa a unei posibile villa.

${ }^{57}$ TIR L 34, 48; Székely 1969, 155-181; Mitrofan 1973, 133-136; RACJ, 114, nr. 5-6; Popa 2002, nr. 178; Gudea 2009, 224, Abb. 32 a

${ }^{58}$ TIR L 34, 65, Floca 1953, 743-754, Mitrofan 1973, 142-144; Popa 2002, nr. 320; Gudea 2009, 225 (Abb. 33 ), 309

${ }^{59}$ Mitrofan 1973, 138-140; Gudea 2009, 225 (Abb. 33), 282

${ }^{60}$ Branga 1978, 88-97; Branga 1980, 164-186; Gudea 2009, 229 (Abb 37), 308

${ }^{61}$ Branga 1986, 145-164, 146, pl. 24; Popa 2002, nr. 30/2; Gudea 2009, 228 (Abb. 36/1), 308

${ }^{62}$ Branga 1986, 189-201; Gudea 2009, 227 (Abb. 35), 309

${ }^{63}$ Székely 1969, 155-181; Gudea 2009, 230-231, 251, 308-309

${ }^{64}$ Vezi discutia la Mitrofan 1973, 133 şi nota 18.

${ }^{65}$ Cf. Mitrofan 1973, 129

${ }^{66}$ Spre deosebire de cele două cazuri citate, pentru edificiul E3 nu avem niciun indiciu cu privire la o funcţionalitate sacră, doar dezvelirea întregului ansamblu de la Tărtăria II putând clarifica astfel de detalii.

${ }^{67}$ Analiza cantitativă a stadiului cercetării unor astfel de aşezări, realizată de Nicolae Gudea (Gudea 2009, 200-201), reflectă următoarea situație: Dacia Porolissensis - 43 de puncte de interes (dintre care doar şase parțial cercetate și 37 identificate prin cercetări de suprafałă şi descoperiri întâmplătoare), Dacia Apulensis - 109 de puncte de interes (dintre care 37 parțial cercetate şi 72 identificate prin cercetări de suprafaţă și descoperiri întâmplătoare) şi Dacia Malvensis 74 de puncte de interes (dintre care 12 parțial cercetate şi 62 identificate prin cercetări de suprafał̧ă şi descoperiri întâmplătoare).

${ }^{68} \mathrm{O}$ clasificare a tuturor aşezărilor rurale din provinciile dacice în funcţie de caracteristicile şi elementele constitutive, precum şi o clasificare a sistemului de habitat specific acestora, realizată prin sintetizarea stadiului cercetării în acest domeniu, este disponibilă la Gudea 2009, 200-223; 264-297.

${ }^{69}$ Gaiu 2004, 126 şi pl. 2 
Mediaş IV $^{73}$, Obreja ${ }^{74}$, Slimnic ${ }^{75}$, Sf. Gheorghe-lernut ${ }^{76}$, Cioroiul Nou ${ }^{77}$, Locusteni ${ }^{78}$ etc. În combinație cu structuri în construcția cărora a fost utilizată şi piatra, locuințe de acest tip sunt semnalate la Chinteni $^{79}$, Cicău ${ }^{80}$, Ghirbom ${ }^{81}$, Micăsasa ${ }^{82}$, Gornea $^{83}$, Petreşti ${ }^{84}$, Sebeș ${ }^{85}$ și Sânmiclauş ${ }^{86}$, pentru a le menționa pe cele mai reprezentative.

Dacă pentru Dacia prezența şi analizarea acestui tip de locuire, din perspectiva unei constante la fel de caracteristice epocii romane ca și tipul de locuire în clădiri/edificii, face parte dintr-un discurs istorico-arheologic de dată relativ recentă $\check{~}^{87}$, pentru provincia învecinată, respectiv Pannonia, locuințele de acest tip reprezintă o parte însemnată a habitatului specific epocii romane $^{88}$. Potrivit tipologiei propuse de Tibor Budai Balogh structurile investigate de noi în cadrul sitului de la Tărtăria II pot fi încadrate după cum urmează: complexele 22 și 27 - Tip II A, complexul 24 - Tip I A, complexul 4 - o variantă a Tipului II B2, iar complexul 10 - o variantă a Tipului II C3 sau Il C4 ${ }^{89}$. Analiza făcută de cercetătorul maghiar asupra acestui tip de amenajări interpretează critic o serie de propuneri de clasificare anterioare ${ }^{90}$, pe care le adnotează prin raportarea la descoperiri arheologice recente ${ }^{91}$. Din punct de vedere funcțional, Budai Balogh propune o interpretare care combină funcția de locuire efectivă cu cea de spațiu de desfășurare a unor activități economice diverse ${ }^{92}$, subliniind imposibilitatea atribuirii etnice a acestui tip de locuire, acesta fiind o constantă pentru tot spațiul danubian în perioada Latène, fiind preluat și transmis în creuzetul de civilizație materială şi spirituală reprezentat de Imperiul Roman. Lipsa semnalărilor de acest tip de dependințe şi anexe pentru structurile de tip villa cercetate în Dacia se explică mai curând prin stadiul cercetării și nu printr-o excepție constituită de situl de la Tărtăria II.

Un ultim aspect legat de arhitectura ansamblului de la Tărtăria II este cel legat de prezența şanțului de delimitare. Majoritatea cercetătorilor acestui aspect al antichității consideră că unul dintre criteriile de interpretare a unei structuri romane ca fiind villa este constituit de prezența unui spaţiu definit de o incintă ${ }^{93}$. Aceasta poate îmbrăca forma complexă a unui zid, dar sunt luate în considerare şi alte modalităţi de definire a perimetrului (garduri, sistem de şanţ cu val, şanţuri simple sau sistem de şanţuri paralele şi concentrice, garduri vii etc. $)^{94}$. În Dacia sunt, atestate arheologic, complexe de clădiri în interiorul unor incinte de zid, de forme şi dimensiuni diferite, cele mai reprezentative fiind cele investigate la Deva ${ }^{95}$, Apoldul de Sus - Curtea Velii ${ }^{96}$, Sântămăria

${ }^{70}$ Benea 1996, 304

${ }^{71}$ Gudea 2009, 209, Abb.17

${ }^{72}$ Bejan, Benea 1985, 187-197

${ }^{73}$ Winkler, Blăjan 1993, 459-476; Gudea 2009, 289

${ }^{74}$ Protase 1980, 57-63; Protase 2002; Popa 2002, nr. 433

${ }_{75}^{75}$ TIR L 35, 68; Glodariu 1972, 119-140; 1981; Popa 2002, nr. 599; Gudea 2009, 294

${ }^{76}$ Popa 2002, nr. 591; Gudea 2009, 293

${ }^{77}$ Tudor 1978, 228; TIR L 35, 34

${ }_{78}^{78}$ Popilian, Bondoc 2014, 71-90, 120 și urm.; TIR L 34, 67

${ }^{79}$ Matei 1974-1975, 299-302; Popa 2002, nr. 158

${ }^{80}$ Winkler, Takács, Păiuș 1979; Popa 2002, nr. 164

${ }^{81}$ Popa 2002, nr. 291; Gudea 2009, 283

${ }^{82}$ Protase 1980, 55; Popa 2002, nr. 409

${ }^{83}$ Gudea 1973, 569-573; Gudea 1977, 12-37

${ }^{84}$ Popa 2002, nr. 473

${ }^{85}$ Popa 2002, nr. 568; Gudea 2009, 293

${ }^{86}$ Anghel, Blājan 1979, 488-492; Popa 2002, nr. 567

${ }^{87}$ Anterior, astfel de structuri sunt utilizate pentru justificarea temei continuităţii populaţiei autohtone şi romanizării rapide și intensive a acesteia (Cazul Obreja, Slimnic, Locusteni).

${ }^{88}$ Budai Balogh 2009, 77-110, 80 (Abb. 1)

${ }^{89}$ Budai Balogh 2009, 85

${ }^{90}$ Meduna 1980, 48-61; Budai Balogh 2009, 83-84

${ }^{91}$ Budai Balogh 2009, 83-84

${ }^{92}$ Budai Balogh 2009, 83-84

${ }^{93}$ Vezi la Smith 2002, 144-171 întreaga discuție cu privire la tipurile, caracteristicile și modul de utilizare a structurilor considerate curte, în legătură cu construcțiile de tip villa. De asemenea, Henning 1987, 22-30, cu privire la clasificarea vilelor pentru sud-estul Europei, precum şi discuția cu privire la ansamblurile din Dacia la Gudea 2009, 228-229.

${ }^{94}$ Vezi discuţia la Smith 2002, 144-171

${ }^{95}$ Mărghitan 1998, 303-342; Mitrofan 1973, 138-140; Gudea 2009, 225 (Abb. 33), 282 
Orlea $^{97}$, Ciumăfaia ${ }^{98}$, Hobița - Grădiște ${ }^{99}$ și Miercurea - Coșcane ${ }^{100}$. Până în acest moment nu cunoaștem, în provincia Dacia un sistem de delimitare de acest tip, din motive similare celor invocate pentru prezența în interiorul ansamblurilor de tip villa a unor bordeie, respectiv stadiul cercetării și numărul mic al unor astfel de ansambluri pentru care s-a putut realiza o cercetare în suprafață ${ }^{101}$. Pentru alte provincii din Imperiu delimitarea cu şanțuri este documentată și considerată, de asemenea, o manifestare moștenită de la sistemul de habitat și de exploatare agricolă specifice perioadei pre-romane, preluarea acestuia în epocă romană fiind considerată a fi un indiciu al romanizării. Interesante, din acest punct de vedere sunt asemănările dintre sistemul de delimitare de la Tărtăria II şi cele de la Kaiserteinbruch - Königshof ${ }^{102}$ (Pannonia), Uplyme Holcombe (Britannia) ${ }^{103}$ şi Manfield Holme House (Britannia) ${ }^{104}$. Cea mai fidelă analogie a sistemului de delimitarea constatată pentru situl roman de la Tărtăria II provine însă din Pannonia - Gönyü, Nagy-Sáros - şi este legată, însă, de o structură de supraveghere, a drumului roman de la Aquincum la Carnuntum ${ }^{\text {i05. }}$.

Având în vedere cele prezentate în rândurile anterioare, considerăm că structurile cercetate în cadrul sitului de la Tărtăria II pot fi considerate ca fiind legate de prezența unei villa şi existența unei exploatații agricole în zonă. Problemele de interpretare derivă din disproporția dintre datele disponibile pentru prima fază de funcționare și cea de-a doua. Astfel, este certă o prezență și o ocupare a spațiului în prima jumătate a secolului al II-lea, atât pentru punctul Tărtăria II, cât şi pentru zona din imediata vecinătate. Urmează o perioadă, destul de însemnată, acoperind în mare parte domniile lui Antoninus Pius, Marcus Aurelius şi Commodus, pentru care nu avem indicii arheologice şi nici semnalări de descoperiri întâmplătoare în zonă. Edificiile și amenajările din această primă fază sunt modeste și legate de o ocupaţie agricolă, după cum indică materialul arheologic provenit din contextul stratigrafic atribuit acestei prime faze.

Este frapantă maniera de debut a celei de-a doua faze, cu schimbări drastice de utilizare a spațiului, unicul element preluat de la faza anterioară fiind șanțul de delimitare, ceea ce ne indică o posibilă schimbare de proprietar. Situația arheologică constatată pentru cea de-a doua fază, materialul arheologic și analiza materialului numismatic, plasează începutul celei de-a doua faze în perioada severiană şi indică o funcționare care urcă până la o dată ulterioară anului 246 (cea mai târzie monedă descoperită în conexiune cu clădirile care formează ansamblul).

Ipoteza schimbării de proprietar ridică însă o serie de probleme în legătură cu maniera de transfer a proprietății. În cazul nostru putem avansa trei ipoteze:

1. Terenul pe care se dezvoltă este inițial ager publicus, iar primul ocupant are doar posesia şi folosința. În acest caz, se află într-un teritoriu pentru care nu se aplică ius italicum. Poate transmite posesia, succesoral sau către un alt partener, prin mijloacele şi modalităţile stipulate de dreptul roman.

2. Terenul este ager publicus, iar primul ocupant pierde, printr-un concurs de împrejurări, posesia, lotul fiind probabil realocat prin atribuire individuală (adsignatio viritim), caz în care s-ar explica hiatusul constatat de noi în cazul Tărtăria II.

3. Primul proprietar are asupra terenului o proprietate deplină dominium ex iure Quiritium şi poate efectua tranzacții de drept civil de tip mancipatio, usucapio şi in iure cessio. În acest caz,

${ }^{96}$ Branga 1986, 145-164, 146, pl. 24; Popa 2002, nr. 30/2; Gudea 2009, 228 (Abb. 36/1), 308

${ }^{97}$ TIR L 34, 103; Tudor 1968, 109; Mitrofan 1973, 148; Popa 2002, 576/1; Gudea 2009, 310

${ }^{98}$ TIR L 34, 48; Székely 1969, p. 155-181; Mitrofan 1973, p. 133-136; Rep. Arh. Cluj, 114, nr. 5-6; Popa 2002, nr. 178; Gudea 2009, 224, Abb. 32 a

${ }^{99}$ TIR L 34, 65, Floca 1953, 743-754, Mitrofan 1973, 142-144; Popa 2002, nr. 320, Gudea 2009, 225 (Abb. 33 ), 309

${ }^{100}$ Branga 1986, 189-201; Gudea 2009, 227 (Abb. 35), 309

101 Situația este sesizată și de J.T. Smith în analiza stadiului cercetării vilelor romane în Europa de sud-est: „Nevertheless, it is strange, in view of the determination implicit in the extent of digging on sites where the lack of mosaics, hypocausts and baths would have discouraged many west European archaeologists, that boundary ditches or banks were either not recognised or not reported, because it is impossible to believe that none such existed.", Smith 2002, 212-213.

102 Thomas $1964,152-154$

${ }^{103}$ Smith 2002, 242

${ }^{104}$ Smith 2002, 247

${ }^{105}$ Bíró 2010, 133-158 
el este cetățean roman dintr-un teritoriu care beneficiază de ius italicum, iar scenariul ia în considerare faptul că Ulpia Traiana se bucură încă de la fondare de uriaşul avantaj oferit de ius italicum, ceea ce presupune că prin adsignatio ager publicus putea fi transformat în proprietate privată, adică în ager datus adsignatus ${ }^{106}$.

$\mathrm{Nu}$ putem evita o discuție despre prezența monumentului epigrafic descoperit în vecinătatea sitului. Astfel, personajul eternizat în inscripție, $Q$. Valerius Macrinus (?), are patru calități importante: este cetățean roman, este veteran al legiunii a V-a Macedonica ${ }^{107}$, este missicius şi a făcut parte din ordo decurionum al coloniei Sarmizegetusa. În calitate de cetățean roman face parte din corpul de cives romani optimo iure, cu toate avantajele ce decurg din aceasta, dintre care cea mai importantă, în cazul nostru, este scutirea de impozitul funciar. Calitatea de veteran al legiunii a V-a Macedonica presupune că el își termină serviciul militar într-o perioadă post 168 170 p. Chr. ${ }^{108}$, la care se adaugă anii în care are calitatea de missicius, fiind în continuare la dispoziţia trupei în care a servit. Este puţin probabil ca apartenența sa la ordo decurionum al Sarmizegetusei să se fi produs în paralel cu calitatea de missicius, astfel încât putem situa cronologic accesul acestuia în elita municipală a capitalei Daciei cândva începând cu perioada severiană, ceea ce este în perfect acord cu datarea fazei a doua din cadrul sitului de la Tărtăria II. Calitatea de decurion presupune însă o proprietate funciară în teritoriul oraşului în care îşi exercită magistratura şi, mai ales, un cens ridicat, calculat pe baza veniturilor obținute din activități acceptate, fiind preferate cele derivate din proprietăți funciare. Nu știm nici dacă personajul nostru a îndeplinit vreo magistratură sau a fost doar simplu pedan ${ }^{109}$.

Este puțin probabil să ne aflăm în faţa unei aşa numite „pietre călătoare”, astfel încât, putem considera că locul de înmormântare a personajului este pe proprietatea pe care o deține, probabil de-a lungul drumului de la poalelele platoului Tărtăria ${ }^{110}$.

Dealtfel, legătura dintre $Q$. Valeriu Macrinus şi o posibilă proprietate funciară în zona Tărtăria este utilizată de Ioan Piso ca argument în stabilirea limitelor teritoriului Ulpiei Traiana, pentru sfârşitul secolului al II-lea p. Chr. ${ }^{\prime \prime \prime}$, iar personaje ce fac parte din ordo, cu proprietăți aflate la distanţe mai mari sau mai mici de capitala provinciei mai sunt atestate epigrafic. Este cazul lui M. Aurelius Valentinus ${ }^{12}$, Grattius Paternus ${ }^{113}$, Lucius Grattius $^{14}$, pentru care Lucrețiu Mihăilescu-Bârliba sugerează proprietăți funciare în zona Strei - Călan ${ }^{115}$.

Evoluția lui $Q$ Valerius Macrinus, de la cariera militară către cea de proprietar și apoi membrul al aristocrației municipale este similară cu cea a altor proprietari de villae din provincie. Amintim aici cazul lui $P$. Aelius Iulius, veteranus și ex centurione ${ }^{116}$ și al fiului acestuia, $P$. Aelius Maximus $^{117}$, și el militar, iar apoi decurio, duumvir quinquennalis şi flamen al coloniei Napoca ${ }^{118}$,

${ }^{106}$ Bleiken 1974, 359-367

${ }^{107}$ În lectura propusă de autorii IDR III/3. Potrivit lui Florian Matei-Popescu, inscripția prezintă o serie de probleme de lectură şi de încadrare cronologică. Astfel, într-un studiu ce urmează a fi publicat, acesta propune o încadrare în prima jumătate a secolulului al II-lea p. Chr., precum şi o nouă variantă de întregire, caz în care, inscriptia s-ar afla în legătură cu prima fază romană din cadrul sitului de la Tărtăria II. Calde mulţumiri lui Florian Matei-Popescu pentru discuțiile, sugestiile și observațiile cu privire la acest subiect, în perioada de redactare a prezentei lucrări.

${ }^{108}$ Bărbulescu 1987, 78, 82-83. Tot la Bărbulescu 1987 o sintetizare a informațiilor cu privire la data de sosire în Dacia a Legiunii a V-a Macedonica, precum și studiul prosopografic.

${ }^{109} \mathrm{O}$ analiză completă a carierelor municipale, precum și bibliografia problemei, la Ardevan 1998, 130-150.

${ }^{110}$ Vezi mai jos propunerea privind topografia zonei în epoca romană, pe baza noilor descoperiri din perioada $2011-$ 2013.

${ }^{11}$ Piso 1995b, 63-82; Piso 2005, 273-294

112 IDR IIl/3, 17

${ }^{113}$ IDR III/3, 18

${ }^{114}$ IDR III/3, 19

${ }^{115}$ Mihailescu-Bîrliba 2010, 180

${ }^{116}$ ILD nr. 578, nr. 579, nr. 581, nr. 583

${ }^{117}$ Wollmann 1975, 173; ILD, nr. 582

${ }^{118}$ Piso $1980,123-131$ 
proprietari ai villa-ei de la Ciumăfaia. Un alt veteran, T. Flavius Rufus ${ }^{119}$ şi soția acestuia, Iulia Maxima $^{120}$, pot fi puşi în legătură cu villa de la Răhău ${ }^{121}$.

Este greu de identificat modalitatea în care toți acești foști veterani își vor fi constituit proprietățile funciare, dat fiind că în perioada pe care o analizăm se preferă mai degrabă transformarea missio agraria în missio nummaria ${ }^{122}$. Că aceştia vor fi constituit un pilon important al romanizării și al funcționării economice a provinciei stă mărturie excepționala reprezentare iconografică a evoluției foștilor militari de la statutul de veteran la cel de proprietari funciari, culminând cu acela de notabil imortalizată pe stela de la Șeica Micăă ${ }^{123}$.

Datele arheologice oferite de cercetarea sitului de la Tărtăria II ne oferă ocazia să propunem, ca datare pentru inscripția discutată jumătatea secolului al III-lea p. Chr. (considerând decurionatul ca fiind apogeul carierei lui $Q$. Valerius Macrinus).

Concentrarea semnalărilor de proprietăți rurale în zona fertilă din Valea Mureşului mijlociu, pe linia Apulum - Micia și în zona Hațeg este un bun indicator pentru stabilirea limitelor teritoriului Ulpiei Traiana și în acelaşi timp un important reper pentru restabilirea traseului rețelei rutiere a provinciei. Fără îndoială că înflorirea şi dezvoltarea acestora este sigur în legătură cu dobândirea de ius italicum, ceea ce făcea ca o astfel de proprietate, beneficiind de imunitățile specifice, să fie foarte rentabil de exploatat. Cu privire la acest aspect, izvoarele antice referitoare la provincia Dacia sunt extrem de reduse. În esență, întreaga discuție se bazează pe un pasaj din Ulpianus ${ }^{124}$ care indică, în timpul lui Caracalla, cinci cetăți din Dacia care posedau acest uriaş privilegiu (Sarmizegetusa, Napoca, Colonia Apulensis, Potaissa şi Dierna), una cu ius italicum dobândit din timpul lui Traian, iar celelalte patru în timpul lui Septimius Severus. Nu este locul şi nici scopul articolului să intrăm în spinoasa problemă a datei de atribuire a acestui privilegiu pentru cetățile din Dacia ${ }^{125}$, ci doar să sugerăm faptul că analiza situației de la Tărtăria II, precum și coroborarea cu restul datelor legate de proprietățile rurale de pe valea Mureșului mijlociu pot aduce date noi cu privire la această problemă.

Dorim însă să stăruim asupra faptului că, acceptând ideea existenței la Tărtăria II a unei villa, reşedință şi mijloc aducător de venit pentru un proprietar funciar din Dacia de la sfârşitul secolului al II-lea şi începutul secolului următor, pornim de la premisa enunțată de Rivet, potrivit căreia „villa, in Latin, means farm, but a farm wich is integrated into the social and economic organization of the Roman World ${ }^{126}$. Aceasta presupune racordarea sa la principalele elemente ce definesc acest sistem social economic, respective conexiunea cu rețeaua rutieră, accesul la modalitățile considerate profitabile de transport (de exemplu transport pe Mureş) şi existența pieței de desfacere, constituită în principal de structurile urbane şi cvasiurbane. Aceste condiții pentru existența unei proprietăți funciare rentabile sunt prezente în majoritatea indicațiilor autorilor antici referitoare la agricultură ${ }^{127}$, racordarea la o rețea rutieră fiind esențială. Din acest punct de vedere, informațiile obținute pe baza cercetării ansamblului de la Tărtăria II se conectează și completează cu o serie de alte descoperiri recente prilejuite de cercetarea arheologică preventivă pe sectoarele de Autostradă Sibiu - Sebeș, Sebeș - Orăștie și Orăștie - Deva, care aduc importante contribuții la cunoaşterea acestei porțiuni din valea Mureșului mijlociu. Astfel, în afară de construcțiile de la Tărtăria II, urme ale unor structuri romane au fost semnalate la Pianu de $\mathrm{J}_{0{ }^{128}}$, Balomiru de

${ }^{119}$ Ţeposu Marinescu 1982, 124 , nr. 89; IDR III/4, 8

120 Țeposu Marinescu 1982, 140, nr. 162; IDR III/4, 9

121 Despre modalitățile de formare a marilor proprietăți funciare din Dacia şi rolul aristocrației municipale, vezi Piso 1995a, 437-444.

$122 \mathrm{O}$ analiză a rolului veteranilor atestaţi în teritoriul Ulpiei Traiana Sarmizegetusa este făcută de George Cupcea (Cupcea 2011, 241-249), personajul nostru, Q. Valeriu Macrinus lipsind însã din analiza sa.

${ }^{123}$ Römer in Rumänien, Köln 1969, 255, Taf. 86; Țeposu Marinescu 1982, 214, nr. 74

${ }^{124}$ Digeste, 50, 15, 1, 8; 9 (Ulpian, de censibus). Vezi în acest sens şi Ardevan 1987, 117-126.

${ }^{125}$ Vezi în acest sens analiza realizată la Cîrjan 2010, 133-139, critica diverselor ipoteze şi stadiul cercetării referitor la acest subiect, cu toată bibliografia de specialitate, dar şi Ardevan 1998, 111-120.

126 Rivet $1969,176-177$

${ }^{127}$ Bâltâc 2011, 138-139

${ }^{128}$ Cercetări arheologice recente au pus în evidentă unele vestigii romane care pot constitui periferia unui ansamblu de tip villa aflat probabil în exteriorul zonei cercetate preventiv. Situl Pianu de Jos-Lunca Pârâului era localizat între km 
Câmp $^{129}$, Șibot ${ }^{130}$, Gelmar II ${ }^{131}$ (pe malul stâng al Mureşului, în dreptul castrului de la Cigmău) şi Spini $^{132}\left(\mathbf{P l}\right.$. XX/1). Toate aceste situri, dintre care unele extrem de complexe ${ }^{133}$, la care se adaugă, pentru zona cuprinsă între Vinţu de Jos şi Simeria o serie de semnalări de structuri considerate ca aparținând epocii romane indicate de cercetări aeriene ale zonei ${ }^{134}$, precum şi în recentele evaluări şi cercetări prilejuite de lucrările de modernizare a căii ferate Alba Iulia - Simeria ${ }^{135}$, vin să contureze un peisaj arheologic complex, care ridică o serie de probleme de interpretare. Este clar, în acest moment, având în vedere aliniamentul coerent pe care se poziționează aceste noi descoperiri, că toate se raportează la o rețea rutieră, pe care cu greu o mai putem considera secundară. În acest stadiu al cercetării, se conturează o importantă arteră principală (cu un mic tronson surprins dealtfel în cercetarea arheologică ${ }^{136}$ ) din care par să se desprindă o serie de drumuri secundare care urmează culoarele naturale descrise de Valea Pianului, Valea Ciorii, Valea Cugirului, continuând, pe Valea Streiului, către capitala provinciei. În condițiile acceptării, în general, a identificării toponimului Blandiana din sursele principale referitoare la rețeaua rutieră a Daciei romane ${ }^{137}$ cu actuala localitate Vințu de $\operatorname{Jos}^{138}$, precum și a elementelor de topografie și de planimetrie a ansamblului de la Şibot (situat la răscruce cu calea de acces către valea Cugirului ${ }^{139}$ ), ne punem întrebarea dacă nu cumva s-ar impune o reconsiderare a teoriei plasării drumului principal Apulum - Ulpia Traiana, pentru tronsonul Vințu de Jos - Simeria.

Informațiile cu privire la acest aspect sunt destul de consistente. Astfel, Acaţiu Barcsai, la mijlocul secolului al XVII-lea, aminteşte de un „drum slăvit” rămas de la Traian, în părțile Câmpului Pâinii ${ }^{140}$, iar o serie de izvoare topografice din secolul al XVIII-lea fac referire la tronsoane de drum antic în zonă ${ }^{141}$, etichetate ca Römer Weg sau Alter Römer Weg ${ }^{142}$, semnalările de pe această parte a Mureşului fiind mult mai frecvente decât pentru partea dreaptă.

La o examinare atentă a tronsonului de drum dintre Apulum și Aquae (Călan), figurat pe Tabula Peutingeriana - Segmentum VIII, atrage atenția o inadvertență. Astfel, pe această porțiune sunt figurate cinci porțiuni de drum (figurate prin linii frânte ${ }^{143}$ ), teoretic despărțite de localități cărora le sunt atribuite, însă doar patru etichete de identificare (Blandiana, Germisara, Petrae, Aquae). Astfel, între Apulum şi Blandiana este figurat un tronson de $8 \mathrm{MP}$, ceea ce ar corespunde cu distanța Vințu de Jos - Partoș (Alba Iulia). Urmează un tronson de drum pentru care nu există nici un toponim, dar peste care este figurată distanța de $9 \mathrm{MP}$, pentru ca următorul tronson, pentru care nu avem figurată distanța, să se finalizeze cu eticheta Germisara. Urmează apoi distanța dintre Germisara şi Petrae, de 9 MP și cea dintre Petrae și Aquae de 13 MP. Însumate, distanțele figurate pe Tabula Peutingeriana între Blandiana și Petrae reprezintă $17 \mathrm{MP}$, ceea ce, considerând 1000 de paşi ca fiind 1,48 km, ar deveni, în sistemul actual, $25,20 \mathrm{~km}$. Or, indiferent de traseu, distanţa între actualele localități Vințu de Jos şi Simeria este de cca $38 \mathrm{de} \mathrm{km}$. Această inadvertența numerică a fost sesizată anterior în literatura de specialitate, fiind însă interpretată din perspectiva unor greșeli

20+550-20+870 al autostrăzii Sebeș - Orăștie (Damian et alii 2013, 223-224, nr. 131). De altfel, din zonă provine şi un altar votiv, vezi Wollmann 1970, 166, nr. 18.

${ }_{129}$ Dumitrașcu, Rațiu, Dolea 2013, 103-140

${ }^{130}$ TIR L 34, 101; Tudor 1968, 135; Branga 1980, 146; Lipovan 1984, 459-465 (care presupune și el existența unei statio mansio); IDR III/3, 277; RAA, 180; Popa 2002, nr. 629; Popa 2011, 253-262. Cercetările preventive în situl dintre km 9+650-10+150 al Autostrăzii Sebeş - Orăştie la Bâltâc et alii 2012, 230-232, nr. 137.

${ }^{131}$ Damian et alii $2011 \mathrm{a}, 286-287$, nr. 165

${ }_{132}$ Damian et alii $2011,278-279$, nr. 155

${ }^{133}$ Cazul de la Sibot, Bâltâc et alii 2012, 230-232, nr. 137

${ }^{134}$ Oltean 2007, 120-131 şi fig. 5/11 şi 5/2 cu sugestia drumului pe partea stângă a Mureșului.

135 În curs de desfăşurare, la data redactării acestei lucrări.

${ }^{136}$ Bâltâc et alii 2012, 230-232, nr. 137; Dumitraşcu, Rațiu, Dolea, 2013, 103-104

${ }^{137}$ Fodorean 2006, 53-61

${ }^{138}$ Fodorean 2012, 214

${ }^{139}$ Popa 2011 în general pentru sinteza descoperirilor din zonă şi în special pentru epoca romană, 352-364. De asemenea, cu privire la localizarea, la Şibot, a localitătii antice Burticum, Popa 2011, 389-390.

${ }^{140}$ Popa 2011,385 , nota 2209

${ }^{141}$ Popa 2011,385 , nota 2210

${ }^{142}$ Fodorean 2010, 474-475

${ }^{143}$ Fodorean 2006, 25-26 
ale unor copiști târzii ai textului original, în ceea ce privește redarea distanțelor ${ }^{144}$ şi nu din perspectiva omisiunii unei localități. Ori, la o cartare elementară a noilor puncte descoperite cu prilejul cercetărilor preventive din cadrul Programului Național de Cercetare „Autostrada", constatăm faptul că distanța dintre Șibot și Vințu ar acoperi exact cei 9 MP figurați pe linia frântă care pleacă de la Blandiana, iar eticheta Germisara ar putea fi conectată cu structurile de epocă romană semnalate în dreptul castrului de la Cigmău (zona Gelmar II), aflate la o distanță de 12-13 $\mathrm{km}$ actuali față de localizarea sitului de la Şibot (cca 8-9 MP) unde evaluările aeriene presupun un punct de traversare a Mureșului ${ }^{145}$. Astfel, s-ar explica concentrarea de semnalări de clădiri romane în zona Şibot - Balomiru de Câmp ${ }^{146}$ și dezvoltarea ansamblului de la Tărtăria II, în condițiile în care situl de la Şibot ar avea și atribuții legate de cursus publicum, ceea ce i-ar fi conferit o serie de privilegii $^{147}$. Ideea nu e nouă, ea fiind dezvoltată de-a lungul timpului, fără însă a beneficia de argumentația arheologică adusă de noile cercetări de pe acest sector al Mureşului mijlociu de o serie de cercetători, începând cu Vasile Pârvan, care sugerează localizarea aici a anticului Burticum, atestat în alt izvor esențial al topografiei antice a provinciei, respectiv Cosmografia Anonimului din Ravenna ${ }^{148}$. În acest sens, toate aceste structuri, aflate în vecinătatea sitului de la Şibot, cum este cazul clădirii cercetate la Balomiru de Câmp ${ }^{149}$, ar putea face parte din sistemul de depozite şi antrepozite dezvoltat în timpul domniei lui Septimius Severus pe lângă aşezările ce deservesc căi rutiere, ce capătă o importanță crescută în legătură cu annona militaris ${ }^{150}$.

Este evident că toate cele sugerate mai sus sunt ipoteze ce îşi vor găsi, mai devreme sau mai târziu, confirmarea sau infirmarea, în evoluția și rezultatele cercetării, în această permanentă pendulare între Briciul lui Occam și eforturile de rezolvare a Marii Teoreme a lui Fermat în care constă, în esență, fascinaţia arheologiei.

Toate aceste informații vin să îmbogățească cunoștinţele despre valea Mureșului mijlociu, în perioada romană. Astfel, odată cu desfăşurarea lucrărilor de infrastructură rutieră subsumate coridorului 4 paneuropean, dar şi odată cu publicarea integrală a cercetărilor arheologice prilejuite de această investiție, la care se vor adăuga informaţiile aduse de cercetarea în desfăşurare, prilejuită de modernizarea căii ferate Alba Iulia - Simeria, această porțiune, considerată o adevărată ,,autostradă prin istoria românilor" îşi va putea dezvălui cât mai multe dintre taine.

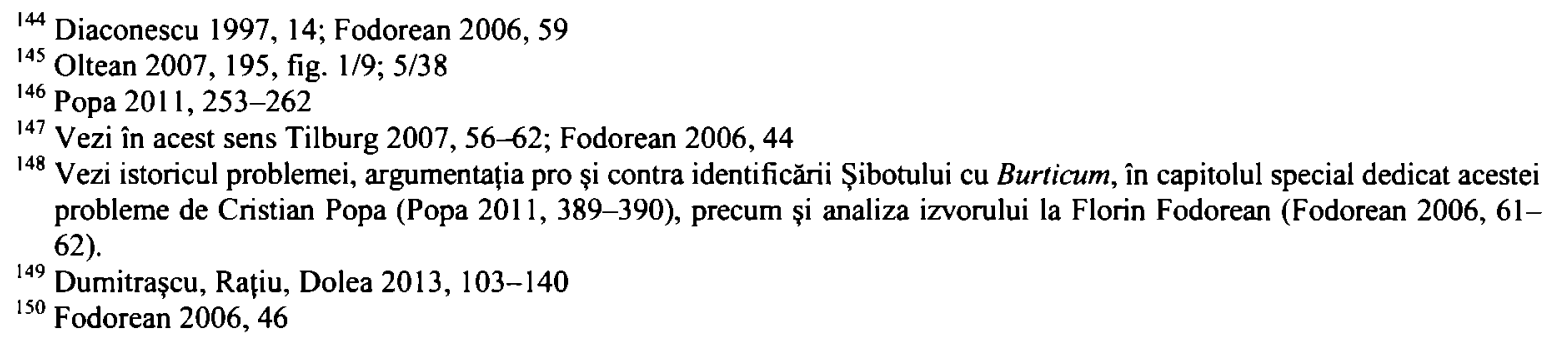


CATALOG SELECTIV AL MATERIALULUI ARHEOLOGIC $^{151}$

1. Bol terra sigillata; PI. XIV/1; formă întregibilă se păstrează baza, o parte din corp şi o parte din buză; $D_{\mathrm{g}}=17 \mathrm{~cm} ; \mathrm{D}_{\mathrm{f}}=9 \mathrm{~cm} ; \mathrm{h}=6 \mathrm{~cm}$; pastă de culoare gălbuie; firnis roșu închis; ștampilă în interiorul bazei: CELSTANIMA; complexul 24; nr. inv. prov. T $2-252$.

2. Farfurie terra sigillata; PI. XIV/2; fund inelar fragmentar; $D_{f}=9,60 \mathrm{~cm}$; pastă de culoare galbenă cărămizie; firnis roșu deschis; ștampilă în interiorul bazei: MARCIANUS; complexul 22; nr. inv. prov. T 2 - 276.

3. Formă nedeterminabilă terra sigillata; $\mathbf{P l}$ XIV/3; fragment de corp; $14,50 \times 5,60 \mathrm{~cm}$; pastă galbenă cărămizie; firnis roșu închis. Decor: ştampilat, pe un singur registru, în care apar: 1) ramuri stilizate, 2) reptile (salamandre?), 3) cercuri de dimensiuni mari, cu striații, fragmentar $(\mathrm{D}=5 \mathrm{~cm})$; complexul 24; Rusu Bolindeț 2007, 632, nr. 98, pl. LXX, 633, nr. 237, pl. LXXI; nr. inv. prov. T $2-250 / 1$.

4. Formă nedeterminată terra sigillata; PI. XIV/4; fragment de corp; 7,80 × 5,50 cm; pastă galbenă cărămizie; firnis roşu închis. Decor: ștampilat, compus din două registre, despărțite de o linie constituită din puncte: 1.1) medalion format din două cercuri concentrice, în interior un bust uman cu capul întors spre stânga; deasupra I.2) decor foarte şters, neidentificabil (motive vegetale?); II.1) cerc de dimensiuni mari, cu striații, fragment $(D=$ $3,5 \mathrm{~cm}$ ). În interior decor șters, neidentificabil (motive animale?); alături II.2) o frunză stilizată, cu vârful în jos; edificiul E2; Rusu Bolindeț 2007, 632, nr. 98, nr. 203, pl. LXX, 633, nr. 275, pl. LXXI; nr. inv. prov. T $2-194$.

5. Formă nedeterminată terra sigillata; PI. XIV/5; fragment de corp; $3,20 \times 2,50 \mathrm{~cm}$; pastă cărămizie; firnis roșu închis. Decor: ştampilat, pe un singur registru: 1) două ove, dintre care una întreagă şi alta fragmentară, despărțite de linii compuse din puncte şi 2) pasăre, cu aripile strânse şi capul întors spre spate; complex 24; Rusu Bolindeț 2007, 633, nr. $243-247$, pl. LXXI; nr. inv. prov. T 2 - 250/2.

6. Amforetă; PI. XIV/6; se păstrează buza, gâtul, o parte din corp și toartele; $\mathrm{D}_{\mathrm{g}}=18,50 ; \mathrm{h}=17 \mathrm{~cm}$; pastă portocalie; secţiunea S 11; Rusu Bolindeț

151 În alcătuirea catalogului au fost utilizate următoarele elemente: denumirea piesei, numărul de planşă, materialul din care este constituită piesa, dimensiuni, descriere, tipul, contextul, bibliografia, numărul de inventar. Abrevieri utilzate: $\mathrm{D}=$ diametru, $\mathrm{D}_{\mathrm{g}}=$ diametrul gurii, $D_{\mathrm{f}}=$ diametrul fundului, $\mathrm{D}_{\max }=$ diametrul maxim, $\mathrm{D}_{\mathrm{int}}=$ diametrul interior, $\mathrm{E}=$ edificiu, $\mathrm{g}=$ grosime, $\mathrm{h}=$ înălţimea, $\mathrm{L}=$ lungime, $\mathrm{l}=$ lăţime, $\mathrm{nr}$. inv. prov. = număr de inventar provizoriu, Sp. = suprafață.
2007, 665, nr. 630, pl. CIII; amforetă de tip 15 B; nr. inv. prov. $\mathrm{T} 2-148$.

7. Amforetă; PI. XIV/7; se păstrează buza, gâtul, o parte din corp și toarta; pastă portocalie; $\mathrm{D}_{\mathrm{g}}=11,20$ $\mathrm{cm} ; \mathrm{h}=13,40 \mathrm{~cm}$; complexul 10; $\mathrm{nr}$. inv. prov. T 2 -148 .

8. Amforetă; Pl. XIV/8; se păstrează buza, gâtul şi o parte din corp; $\mathrm{D}_{\mathrm{g}}=12,50 \mathrm{~cm} ; \mathrm{h}=10,50 \mathrm{~cm}$; buza este deformată, probabil rebut; pastă cenuşie; complexul 24; nr. inv. prov. T 2-232.

9. Mortarium; Pl. XIV/9; se păstrează buza şi o parte din corp; $D_{g}=27 \mathrm{~cm} ; \mathrm{h}=8 \mathrm{~cm}$; pastă cenuşie; buza înclinată, corpul ovoidal, deversor larg; complexul 24; Rusu Bolindeț 2007, 655, nr. 559, pl. XCIII; mortarium de tip 9A; nr. inv. prov. T 2 244.

10. Platou; Pl. XV/10; formă întregibilă, păstrată în proporție de $20 \% ; D_{g}=24 \mathrm{~cm} ; D_{\mathrm{f}}=19 \mathrm{~cm} ; \mathrm{h}=5,60$ $\mathrm{cm}$; pastă semifină, de culoare galbenă, arsă oxidant; firnis roșu deschis; complexul 24; Rusu Bolindeț 2007, 653, nr. 545, pl. XCI; tip B5; nr. inv. prov. T $2-315$.

11. Castron ?; PI. XV/11; formă întregibilă, păstrată în proporție de $50 \% ; \mathrm{D}_{\mathrm{g}}=19 \mathrm{~cm} ; \mathrm{D}_{\mathrm{f}}=7 \mathrm{~cm} ; \mathrm{h}=$ $10,2 \mathrm{~cm}$; pastă galbenă portocalie; buza ușor înclinată, o singură toartă păstrată, cu canelură; pe corp, două caneluri pronuntate, dispuse sub buză și în partea inferioară, marcând zona dintre corp și bază, fundul inelar; complexul 24; nr. inv. prov. T 2 -253 .

12. Cană; PI. XV/12; formă întregibilă, păstrată în proporţie de $90 \% ; D_{g}=6,40 \mathrm{~cm} ; D_{\digamma}=3,20 \mathrm{~cm}$; pastă de culoare gălbuie, urme vagi de ardere secundară pe exterior; buză dreaptă, trei toarte dispuse simetric, gât larg, cilindric, corp bitronconic, bază inelară; Sp. 5, exteriorul zidului de est al E2; nr, inv. prov. T $2-200$.

13. Turibulum; PI. XV/13; fragment de buză, corp și bază; $D_{g}=28 \mathrm{~cm} ; D_{f}=9 \mathrm{~cm} ; \mathrm{h}=18 \mathrm{~cm}$; pastă gălbuie, arsă oxidant; buza decorată cu alveole mari, ovale, realizate prin presarea cu degetele a celor două margini, când pasta este crudă; corpul tronconic; locul de joncțiune dintre corp şi piedestal este decorat cu un brâu incizat; în interior, urme de ardere secundară; complexul 10 ; nr. inv. prov. T 2 133.

14. Turibulum; PI. XV/14; fragment de buză; $\mathrm{D}_{\mathrm{g}}=$ $24 \mathrm{~cm} ; \mathrm{h}=5 \mathrm{~cm}$; pastă portocalie, arsă oxidant; buză decorată cu alveole mari, ovale, realizate prin presarea cu degetele a celordouă margini, când pasta este crudă; urme de ardere secundară, pe interior; complexul 24; nr. inv. prov. T 2-244.

15. Opaiț; PI. XV/15; lipsește o parte din disc; $\mathrm{L}=8$ $\mathrm{cm} ; \mathrm{h}=2,50 \mathrm{~cm} ; \mathrm{D}_{\text {disc }}=3,40 \mathrm{~cm} ; \mathrm{D}_{\text {baza }}=4 \mathrm{~cm}$; pastă portocalie; formă ovală, bordura care încadrează discul este prevăzută cu trei butoni dispuși simetric. În zona dintre rezervor și disc este prevăzută o perforație pentru tiraj. Cioc alungit, cu un arzător, rezervor conic, baza uşor concavă; urme 
de ardere secundară pe cioc; complexul 22; tip Loeschcke X; nr. inv. prov. T $2-236$.

16. Opaiţ; PI. XV/16; toartă; $h=8,50 \mathrm{~cm} ; 1=6,50$ cm; pasta fină, cărămizie; în formă de frunză, prezintă nervură axială dorsală. Pe fața piesei este reprezentată o acvilă, cu capul întors către dreapta și aripile desfăcute. Probabil provine de la un opaiț trilychnis; descoperită în urma unui sondaj geologic, efectuat anterior cercetării arheologice; nr. inv. prov. T $2-996$.

17. Figurină copil; Pl. XV/17; $h=3,20 \mathrm{~cm} ; 1=3,60$ cm; fragment (se păstrează o parte din față); pastă fină, de culoare cărămizie, arsă inegal; lucrată în tipar bivalv, statueta reprezintă un cap de copil, urechi profilate, buze cămoase, nasul turtit şi ochii mari. Probabil este o statuetă de teracotă - bust de copil pe soclu; complexul 3; Ciobanu, Rodean 1997, 177-197; nr. inv. prov. T $2-84$.

18. Fusaiolă; Pl. XV/18; întreagă; $D=3,70 \mathrm{~cm}$, $\mathrm{D}_{\text {orificiu }}=1,20 \mathrm{~cm}, \mathrm{~h}=2 \mathrm{~cm}$; pastă grosieră, arsă precar; formă cilindrică, perforată pe mijloc; complexul 24; nr. inv. prov. T $2-225$.

19. Jeton ?; Pl. XV/19; sticlă; culoare neagră; D = $1,70 \mathrm{~cm} ; \mathrm{h}=0,30 \mathrm{~cm}$; formă circulară, aplatizată; pe margine prezintă două urme rezultate în urma încercării de a perfora piesa; Sp. 5 ; nr. inv. prov. T $2-102$.

20. Jeton; Pl. XV/20; fragment (se păstrează jumătate din piesă); sticlă, culoare neagră; $D=2,70$ $\mathrm{cm} ; \mathrm{D}_{\text {orifíciu }}=0,50 \mathrm{~cm} ; \mathrm{h}=0,80 \mathrm{~cm}$; formă circulară, de culoare neagră, prevăzut cu un orificiu în mijloc. Este decorat cu arce de cerc de culoare albă; Sp. 2; nr. inv. prov. T $2-332$.

21. Fibulă; PI. XVI/21; bronz; L = 5,70 cm; resortul bilateral, corpul de formă circulară în secţiune, portagrafa trapezoidală; tip Latène târziu (Almgren 15, Cociș 3a); complexul 7; începutul secolului al IIlea; Cociş 2004, 225, pl. I/4; nr. inv. prov. T $2-186$.

22. Fibulă; PI. XVI/22; bronz; fragmentară, piciorul contorsionat; $\mathrm{L}=5,3 \mathrm{~cm}$; resort bilateral cu 12 spire, corpul arcuit, rectangular în secțiune; tip fibulă cu picior întors pe dedesubt (Diaconu 1,2 , Cociş 37a5a); complex 7; sfârşitul secolului al IIlea - începutul secolului al III-lea; Cociş 2004, 390, pl. CXXXV/1889; nr. inv. prov. T $2-128$.

23. Fibulă; PI. XVI/23; bronz; ac lipsă; $L=5,60$ $\mathrm{cm}$; este prevăzută cu balama, corpul este semicircular, piciorul este scurt şi se termină într-un buton; tipul Aucissa (Grbić II, Cociş 14d4a); complexul 24; a doua jumătate a sec. II - primele decenii ale secolului al III-lea; Cociş 2004, 304, nr. 716-725, pl. L; nr. inv. prov. T $2-288$.

24. Fibulă; PI. XVI/24; bronz; ac lipsă; $L=5,40$ cm; resortul alcătuit din opt spire, pe corp este prevăzută o nodozitate aplatizată, piciorul este de formă triunghiulară în secţiune şi se termină într-un buton, portagrafa de formă trapezoidală; tip fibulă puternic profilată (Almgren 70, Cociș 8a8b2a); E 2; prima jumătate a secolului al II-lea; Cociş 2004, 269 , pl. XV/208; nr. inv. prov. T $2-177$.
25. Fibulă; Pl. XVI/25; fier; în curs de restaurare; lipsește acul; $L=7,20 \mathrm{~cm}$; corpul de formă triunghiulară, sistemul de închidere este cu balama, iar portagrafa este de formă trapezoidală; tip Alesia (Cociș 13b2); complexul 24; secolul al II-lea; Cociș 2004, 298, nr. $653-656$, pl. XLIV; nr. inv. prov. T $2-289$.

26. Fibulă; PI. XVI/26; fier; în curs de restaurare; lipseşte acul, corpul este rupt în două bucăți; $L=$ $5,10 \mathrm{~cm}$; sistemul de închidere este prin resort, iar corpul este arcuit, de formă rectangulară, în secțiune; tip fibulă cu picior întors pe dedesubt, (Diaconu 1,2, Cociş 37a5a); E3; sfârșitul secolului al II-lea - începutul secolului al III-lea; Cocis 2004, 390, pl. CXXXV/1889; nr. inv. prov. T $2-51$.

27. Fibulă; PI. XVI/27; fier; în curs de restaurare; lipseşte acul; $d=3,90 \mathrm{~cm}$; corpul fibulei are forma literei $\Omega$, sistem de închidere cu balama; tip fibulă Omega (Feugère 30b, Cociş 28al); Sp. 3; mijlocul secolului al II-lea - secolul al III-lea; Cociş 2004, 366 , nr. 1574, pl. CXII; nr. inv. prov. T $2-59$.

28. Ac de cusut; Pl. XVI/28; bronz; $L=12,20 \mathrm{~cm}$, $\mathrm{D}=0,3 \mathrm{~cm}$; partea superioară este lățită în formă de migdală şi prezintă o perforație de formă dreptunghiulară, tija este circulară în secțiune, vârful ascuțit; tip ac de cusut cu urechiuşă despicată; complexul 24; nr. inv. prov. T $2-282$.

29. Ac de podoabă; Pl. XVI/29; bronz; L $=9,20$ $\mathrm{cm}, \mathrm{D}=0,20 \mathrm{~cm}$; capul alcătuit din două părți: o parte în formă de con de pin urmată de o porțiune de formă paralelipipedică: partea conică este decorată cu striuri oblice, iar partea paralelipipedică fațetată cu triunghiuri, tija estre circulară, în secțiune, vârful este ascuțit; complexul 24 ; nr. inv. prov. T $2-248$.

30. Ac de podoabă; Pl. XVI/30; bronz; L $=9,01$ $\mathrm{cm}, \mathrm{D}=0,35 \mathrm{~cm}$; capul profilat, cu coaste multiple, tija estre circulară, în secțiune, vârful ascuțit; complex 10; nr. inv. prov. T $2-135$.

31. Ac de podoabă; Pl. XVI/31; bronz; capul parțial păstrat, tija îndoită; $L=12,70 \mathrm{~cm}, \mathrm{~d}=0,30 \mathrm{~cm}$; capul perforat, prezintă două striuri, tija este circulară în secțiune; E3; nr. inv. prov. T $2-165$.

32. Buton de casetă; Pl. XVII/32; bronz; $L=2,30$ $\mathrm{cm}, \mathrm{D}_{\text {bază }}=2 \mathrm{~cm}, \mathrm{D}_{\max }=2,50 \mathrm{~cm}$; piesa este în formă de clopoțel, iar baza, de formă circulară prezintā o perforație pentru montarea tijei; E5; nr. inv. prov. T $2-202$.

33. Cataramă; PI. XVIV/33; bronz; L $=4,40 \mathrm{~cm}, \mathrm{I}=$ $2,20 \mathrm{~cm}$; cataramă cu carabinieră și sistem de prindere cu nit; complexul 27; nr. inv. prov. T $2-247$.

34. Aplică; Pl. XVII/34; bronz; D $=2,70 \mathrm{~cm} ; \mathrm{g}=$ $0,20 \mathrm{~cm}$; formă circulară, uşor concavă, decorată cu raze; în mijloc prezintă o perforație de formă pătrată; complexul 27; nr. inv. prov. T $2-302$.

35. Obiect de plumb (ramă ?); PI. XVII/35; plumb; $\mathrm{D}=4 \mathrm{~cm} ; \mathrm{g}=0,2 \mathrm{~cm}$; lipsește partea centrală și de jos; formă semicirculară, decorată cu raze, în relief; pe spatele piesei un sistem de prindere, păstrat parțial; Sp. 3; nr. inv. prov. T 2 - 117. 
36. Vârf de săgetă; Pl. XVII/36; fier; în curs de restaurare; $L=9 \mathrm{~cm}$; vârful de tip romboidal, lung, tija rectangulară, în secțiune; complexul 22. nr. inv. prov. T $2-237$.

37. Limbă de curea; PI. XVII/37; bronz; L $=2,40 \mathrm{~cm}$, $\mathrm{l}=1,10 \mathrm{~cm}$; complexul 7; $\mathrm{nr}$. inv. prov. T $2-201$.

38. Buton; PI. XVII/38; bronz; $d=1,6 \mathrm{~cm} ; \mathrm{h}=0,8$ $\mathrm{cm}$; buton în formă de calotă; complexul 22 ; $\mathrm{nr}$. inv. prov. T $2-392$.

39.Vârf de săgetă; PI. XVII/39; fier; în curs de restaurare; $L=12 \mathrm{~cm}$; vârful de tip romboidal, lung, tija rectangulară, în secțiune; complexul 22; nr. inv. prov. T 2-209.

40. Cuțit; PI. XVIIL/40; fier; în curs de restaurare; $L_{\text {lamåa }}=16,50 \mathrm{~cm}, L_{\text {tijà mâner }}=6,50 \mathrm{~cm}$; cuțit cu un singur tăiş, lama ușor arcuită, prevăzut cu tijă pentru montarea mânerului; E2; nr. inv. prov. T 2 66.

41. Cuțit; PI. XVIIL/41; fier; în curs de restaurare; se păstrează doar lama; $L=18 \mathrm{~cm}$; cuțit cu un singur tăiș, lamă uşor arcuită; complexul 24; nr. inv. prov. T $2-287$.

42. Cuțit; PI. XVIIV/42; fier; în curs de restaurare; $\mathrm{L}_{\text {lamã }}=9,50 \mathrm{~cm} ; \mathrm{L}_{\mathrm{rijã} \mathrm{mâner}}=6,50 \mathrm{~cm}$; cu un singur tăiş, lamă uşor arcuită, prevăzut cu tijă pentru montarea mânerului; E3; nr. inv. prov. T $2-52$.

43. Simpulum ?; Pl. XVIII/43; fier; mânerul rupt; în curs de restaurare; $L=17 \mathrm{~cm}$; vas de fier de formă semisferică, prevăzut cu mâner de formă circulară în secțiune; E3; nr. inv. prov. T $2-162$.

44. Fier de plug ?; PI. XVIII/44; fier; în curs de restaurare; $L=10,10 \mathrm{~cm} ; \quad I=4,50 \mathrm{~cm} ;$ lamă triunghiulară, cu vârful rotunjit şi nervură de-a lungul laturii interne, mânerul este scurt, sistem de înmănuşare constituit din două aripi îndoite; E2; nr. inv. prov. T $2-65$.

45. Seceră; PI. XVIII/45; fier; în curs de restaurare; $\mathrm{L}$ mâner $=13 \mathrm{~cm}, \mathrm{~L}=$ lamă $38 \mathrm{~cm}$; lama arcuită, mânerul de prindere este circular în secțiune; E3; $\mathrm{nr}$. inv. prov. T $2-166$.

46. Monedă; Pl. XIX/46; Traian. $98-117$ p. Ch. Denar. Argint. 3,19 g, D =1,70 cm. Emisă 98-99 p. Chr.; RIC II, 247, nr. 33; E3 ?; nr. inv. prov. T 2 338.

47. Monedă; PI. XIX/47; Iulia Domna. 193-211 p. Chr. Denar. Argint. 3,01 g, D =2,10 cm. Emisă 200 p. Chr.; RIC IV (1), 170, nr. 577; El; nr. inv. prov. T $2-123$.

48. Monedă; PI. XIX/48; Iulia Domna ? 193-211 p. Chr. Bronz. 15,03 g, D = 2,60 cm; complexul 24; nr. inv. prov. T $2-223$.

49. Monedă; PI. XIX/49; Caracalla. 211-217 p. Chr. Denar. Argint. 1,91 g, D = 1,90 cm. RIC IV (1), 246, nr. 240. Sp. 3. complexul 7 ?; nr. inv. prov. T $2-301$.

50. Monedă; Pl. XIX/50; Gordian al III-lea. 238244 p. Chr. Bronz. Sestert. 19,58 g, D = 2,70 cm. RIC IV (3), 48, nr. 304(a); E 2; nr. inv. prov. T 2 15.

51. Monedă; PI. XIX/51; Filip Arabul. 244-249 p. Chr. $16,54 \mathrm{~g}, \mathrm{D}=2,60 \mathrm{~cm}, \mathrm{E} 1 ; \mathrm{nr}$. inv. prov. T 2 170.

52. Monedă ilizibilă; PI. XIX/52. Bronz. 17,41 g, D $=2,90 \mathrm{~cm}$; complexul 7; nr. inv. prov. T $2-210$.

BIBLIOGRAFIE

A-RAR

Alicu et alii 1994

Alicu et alii 1995

Anghel, Blăjan 1979

Ardevan 1987

Ardevan 1998

Baumann 1983

Bărbulescu 1987

Bâltâc 2011

Bâltâc et alii 2012
Arhiva Repertoriul Arheologic al României, Institutul „Vasile Pârvan” al Academiei Române (disponibilă on-line, accesată la data de 15.02.2013)

D. Alicu, S. Cociş, C. Ilieș, Alina Soroceanu, Small finds from Ulpia Traiana Sarmizegetusa, Cluj-Napoca, 1994

D. Alicu, S. Cociș, I. Ferencz, Adela Paki, C. Ilieș, Cercetări arheologice la Cluj-Napoca. Villa rustica din Valea Chintăului. Campania 1988, AcıaMN, 32,1995 , p. 619-633

Gh. Anghel, M. Blăjan, Săpăturile arheologice de la Sînmiclăuş - „Gruișor”, comuna Sona, jud. Alba (1978), MCA, 12, 1979, p. 488-492

R. Ardevan, Veterani şi decurioni municipali în Dacia Romană, Sargetia, 20 , 1987, p. 117-126

R. Ardevan, Viaţa municipală în Dacia Romană, Timișoara, 1998

V. H. Baumann, Ferma romană din Dobrogea, Tulcea, 1983

M. Bărbulescu, Din istoria militară a Daciei romane. Legiunea $V$ Macedonica şi castrul de la Potaissa, Cluj-Napoca, 1987

Adela Bâltâc, Lumea rurală în provinciile Moesia Inferior şi Thracia (secolele I-III p. Chr.), Bucureşti, 2011

Adela Bâltâc, P. Damian, Cătălina Neagu, Corina Nicolae, Alina Muşat, Alexandra Dolea, I. Bocan, Ioana Paraschiv-Grigore, E. Paraschiv-Grigore, B. Voicu, V. Apostol, A. Raţiu, M. Vasile, Irina Ene, E. Dumitraşcu, M. Streinu, Andra Samson, D. Ene, M. Duca, E. Ene, S. Dobrotă, F. Munteanu, 
Bejan, Benea 1985

Benea 1996

Benea 2002

Berciu, Berciu 1946-1948

Bíró 2010

Bleiken 1974

Borş et alii 2013

Branga 1978

Branga 1980

Branga 1986

Budai Balogh 2009

Cîrjan 2010

Ciobanu, Rodean 1997

Ciugudean, Ciugudean 1993

Cociş 2004

Cociș et alii 2010

Crova 1942

Cupcea 2011

DA

Damian et alii 2011a

Damian et alii $2011 \mathrm{~b}$

Damian er alii 2013
N. Stoica, G. Băeştean, Şibot, com. Şibot, jud. Alba, Punct: În Obrej (Autostrada Al, lot 1, sit $5-\mathrm{km} \mathrm{9+650-10+150),} \mathrm{CCA,} \mathrm{2013,} \mathrm{nr.} \mathrm{137,} \mathrm{p.}$ 230-232

A. Bejan, Doina Benea, Şantierul arheologic de la Hodoni-Pustă. Raport preliminar 1979-1984, Banatica, Muzeul de Istorieal județului CaraşSeverin, 7, 1985, p. 187-197

Doina Benea, Dacia sud-vestică în secolele III-IV, Timișoara, 1996

Doina Benea, Integrarea provinciei Dacia în sistemul economic al Imperiului Roman, Eph. Nap., 12, 2002, p. 99-112

D. Berciu, I. Berciu, Cercetări şi săpături arheologice în județele Turda şi Alba, Apulum, 2, 1943-1945, p. 31-42

Szilvia Bíró, Eine Straßenstation unter militärischer Überwachung Anmerkungen $z u$ einer römischen Station in Nordwestpannonien, în Römische Raststationen und Straßeninfrastruktur im Ostalpenraum, Innsbruck, 2010, p. 133-158

J. Bleiken, In provinciali solo dominium populi Romani est vel Caesaris, Chiron. Mitteilungen der Kommission für Alte Geschichte und Epigraphik des Deutschen Archäologischen Instituts, München, 4, 1974, p. 359-367

Corina Borş, Luciana Irimuş, V. Rumega, S. Dobrotă, C. Rişcuța, Un nou sit de tip Basarabi. Raport preliminar asupra cercetărilor arheologice preventive la Tărtăria - Podu Tărtăriei Vest (Campania 2012), CA, XX, 2013, p. 9-102

N. Branga, Aspecte şi permanente thraco-romane, Timişora, 1978

N. Branga, Urbanismul Daciei Romane, Timişoara, 1980

N. Branga, Italicii şi veteranii din Dacia, Timişoara, 1986

T. Budai Balogh, Pannonische Grubenhäuser Abriss der römerzeitlichen Geschichte der eingetieften Wohnhäuser, în Bíró Szilvia (ed.), $E X$ OFFICINA ... Studia in honorem Dénes Gabler Györ, 2009, p. 77-110

R. Cîrjan, Statute citadine privilegiate în provinciile dunărene ale Imperiului roman (sec. I-III p. Chr.), Cluj-Napoca, 2010.

R. Ciobanu, N. Rodean, Raport preliminar privind cercetările arheologice de salvare din Dealul Furcilor - Alba Iulia. Campania 1995 (1), Apulum, XXXIV, 1997, p. 177-197

Daniela Ciugudean, $H$. Ciugudean, Un mormânt de războinic geto-dac de la Tărtăria, jud. Alba, Eph. Nap., 3, 1993, p. 77-79

S. Cociş, Fibulele din Dacia Romană, Cluj-Napoca, 2004

S. Cociș, F. Fodorean, A. Ursuțiu, V. Bârcă, Villa rustica de pe dealul Lomb, în H. Pop, I. Bejinariu, Sanda Băcueț-Crişan, D. Băcueț-Crişan (ed.), Identităbi culturale locale şi regionale in context european. Studii de arheologie și antropologie istorică. In memoriam Alexandri V. Matei, Bibliotheca Musei Porolissensis, XIII, Cluj-Napoca, 2010, p. 565-574

B. Crova, Edilizia e Tecnica rurale di Roma antica, Milano, 1942

G. Cupcea, Veteran settlement and Colonia Ulpia Traiana Sarmizegetusa, în I. Piso, Viorica Rusu-Bolindeț, Rada Varga, Silvia Mustaţă, Eugenia BeuDachin, Ligia Ruscu (ed.), Scripta Classica. Radu Ardevan sexagenarii dedicata, Cluj-Napoca, 2011, p. 241-249

C.V. Daremberg, E. Saglio, Dictionnaire des Antiquités grecques et romaines, Paris, 1873, sqq.

P. Damian, I. Bocan, E. Dumitrașcu, Cătălina Neagu, E. Paraschiv-Grigore, D. Vleja, Ioana Paraschiv-Grigore, Gelmar, oraș Geoagiu, jud. Hunedoara (Varianta de ocolire Deva-Orăștie), Punct: Gelmar II, km 1+850-2+050, în CCA, 2012, nr. 165, p. 286-287

P. Damian, I. Bocan, Cătălina Neagu, E. Paraschiv-Grigore, M. Vasile, D. Vleja, E.-S. Ene, Ioana Paraschiv-Grigore, Angelica Bălos, Varianta de ocolire Deva - Orăștie, km 0+000-32+500, jud. Hunedoara, CCA, 2011, nr. 155 , p. $278-279$

P. Damian, I. Bocan, D. Vleja, Mădălina Voicu, C. Cristescu, C.D. Tuţuianu, Pianu de Jos, com. Pianu, jud. Alba Punct: Lunca Pârâului (Autostrada

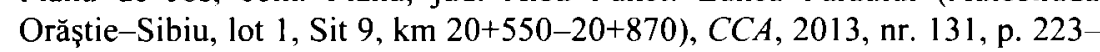
224 
Diaconescu 1997

Diaconu 1971

Digeste

Dumitraşcu, Rațiu, Dolea 2013

Feugère 1985

Floca 1953

Floca, Valea 1965

Fodorean 2006

Fodorean 2010

Fodorean 2012

Gaiu 2004

Glodariu 1972

Gudea 1973

Gudea 1977

Gudea 2009

Gugl 1995

Henning 1987

Horedt 1978

IDR III/3

\section{IDR III/4}

\section{ILD}

Lipovan 1984

Matei 1974-1975

Mărculeț, Mărculeț 2011

Mărghitan 1998

Meduna 1980

Mihăilescu-Bîrliba 2010

Mitrofan 1973

Mitrofan 1974
A. Diaconescu, Dacia under Trajan. Some observation on Roman tactics and strategy, ActaMN, 34, 1, 1997, p. 13-52

Gh. Diaconu, Über die Fibeln mit umgeschlagenem Fuß in Dazien, Dacia N.S., XV, 1971, p. 239-267

The Digest of Iustinian (ed. Th. Mommsen, P. Krueger and Alan Watson) vol. I, Philadelphia, 1985

E. Dumitrașcu, Al. Raţiu, Alexadra Dolea, Cercetări arheologice preventive la Balomiru de Câmp, $C A, X X, 2013$, p. 103-140

M. Feugere, Les fibules en Gaule Meridionale de la conquete a la fin du $V$ eme sieccle apres J.-C., Paris, 1985

O. Floca, Ferma (villa rustica) din epoca sclavagistă romană, $M C A, 1,1953$, p. 743-754

O. Floca, M. Valea, Villa rustica şi necropola daco-romană de la Cinciș, ActaMN, II, 1965, p. 163-192

F. Fodorean, Drumurile din Dacia Romană, Cluj-Napoca, 2006

F. Fodorean, Roman fortresses and roads on Habsburgic and AustroHungarian maps, în H. Pop, I. Bejinariu, S. Băcueț-Crișan, D. Băcueț-Crișan (ed.), Identităti culturale locale şi regionale în context european. Studii de arheologie şi antropologie istorică. In memoriam Alexandri V. Matei, Bibliotheca Musei Porolissensis, XIII, Cluj-Napoca, 2010, p. 469-478

F. Fodorean, "Spa" vignettes in Tabula Peutingeriana. Travelling Ad Aquas: thermal water resources in Roman Dacia, Eph. Nap., 22, 2012, p. 211-222

C. Gaiu, Provincia profundã - imaginea unui sat dacoroman în lumina arheologiei, în C. Gaiu, H. Bodale (ed.), Centru şi periferie Bistriţa, 2004, p. 77-90

I. Glodariu, Așezarea daco-romană de la Slimnic, ActaMN, 9, 1972, p. 119140

N. Gudea, O locuintă romană la Gomea, ActaMN, 10, 1973, p. 569-573

N. Gudea, Gornea. Aşezări din epocă romană și romană târzie, Banatica, Muzeul de Istorieal județului Caraș-Severin, 4, 1977, p. 12-37

N. Gudea, Ländliche Siedlungen in den dakischen Provinzen (106-275 $n$. Chr.). Archäologische Beiträge zur Geschichte des Dorfes und der Landwirtschaft in der Römerzeit, Jahrbuch des Römisch-Germanischen Zentralmuseums, 56, 2009

C. Gugl, Die romischen Fibeln aus Virunum, Klagenfurt, 1995

J. Henning, Südosteuropa zwischen Antike und Mittelalter. Archäologische Beiträge zur Landwirtschaft des 1. Jahrtausends $u$. Z, Berlin, 1987

K. Horedt, Die letzen Jahrzehnte der Provinz Dakien in Siebenburgen, Apulum, XVI, 1978, p. 211-237

I. I. Russu, Oct. Floca, V. Wollmann, Inscriptiile Daciei romane III. Dacia Superior, 3, zona centrală (teritoriul dintre Ulpia Traiana, Micia, Apulum, Alburnus Maior, Valea Crișului), București, 1984

Inscriptiile Daciei Romane = Inscriptiones Daciae Romanae, Vol. III. Dacia Superior, 4. Partea Răsăriteană. Ed. Ioan I. Russu, București, 1988

C. C. Petolescu, Inscriptille latine din Dacia, București, 2005

I.T. Lipovan, Descoperiri arheologice la Şibot (jud. Alba), ActaMN, 21, 1984, p. $459-465$

Al. Matei, O aşezare rurală romană la Chinteni (jud. Cluj), Sargetia, 11/12, $1974-1975$, p. 299-302

I. Mărculeț, Cătălina Mărculeţ, Regionalizarea geografică a Culoarului Orăștiei, Analele Asociafiei Profesionale a Geografilor din România, vol. 2, nr. 2/2011, p. 27-32

L. Mărghitan, Reflecţii asupra romanizării Daciei. Săpăturile arheologice de la Deva, Sargetia, 17/1, 1998, p. 303-352

J. Meduna, Die laténezeitlichen Siedlungen in Mähren, Praga 1980

L. Mihăilescu-Bîrliba, L'origine de l'élite municipale en Dacie romaine, Studia Antiqua et Archaeologica, 16, 2010, p. 153-187

I. Mitrofan, Villae rusticae in Dacia superioară, I, ActaMN, 10, 1973, p. 127-150

I. Mitrofan, Villae rusticae in Dacia superioară, II, $\operatorname{ActaMN}, 11$, 1974, p. 41-59 
Oltean 2007

Paki 1995

Piso 1980

Piso 1995a

Piso $1995 \mathrm{~b}$

Piso 2005

Piso 2008

Popa 2002

Popa 2011

Popa 2012

Popilian, Bondoc 2014

Protase 1980

Protase 2002

RE

RIC II-IV

Richmond 1969

Rivet 1969

Römer in Rumänien

Rusu Bolindeț 2007

Smith 2002

Székely 1969

Thomas 1964

Tilburg 2007

TIR L 34

Tudor 1968

Tudor 1978

Țeposu Marinescu 1982

Winkler, Takács, Păiuș 1979
Ioana Adina Oltean, Dacia. Landscape, colonisation and romanisation, London and New York, 2007

Adela Paki, La Colonisation de la Dacie Romaine, în Regula Frei-Stolba, $\mathrm{H}$. E. Herzig (ed.), La politique édilitaire dans les provinces de l'Empire romain Ilème-IVème siècles après J.-C., Actes du Ile colloque roumano-suisse, Berne, 12-19 septembre 1993, Berna, Berlin, Frankfurt, New York, Paris, Wien, 1995, p. 19-37

I. Piso, Epigraphica XI, Potaissa, 2, p. 123-131

I. Piso, L'aristocratie municipale en Dacie et la grande propriété foncière, în Du Latifundium au Latifondo (Actes de la Table ronde internationale du CNRS organisée à l'Université Michel de Montaigne - Bordeaux III les I719 décembre 1992), Paris, 1995, p. 437-444

I. Piso, Le territoire de la Colonia Sarmizegetusa, Eph. Nap., V, 1995, p. 63-82 I Piso, An der Nordgrenze der Römischen Reiches. Ausgewählte Studien (1972-2003), München, 2005

I. Piso, Les débuts de la province de Dacie, în I. Piso (ed.), Römische Provinz. Begriff und Gründung (Actele colocviului international Cluj, septembrie 2006), Cluj-Napoca 2008, p. 297-331

D. Popa, Villae, vici, pagi. Aşezările rurale din Dacia romană intracarpatică, Sibiu, 2002

C. I. Popa, Valea Cugirului din preistorie până în zorii epocii moderne. Monumenta archaeologica et historica, Cluj-Napoca, 2011

C. I. Popa, Contributii la preistoria Văii Sebeşului I. Locuiri Cotofeni din zona deluroasă, Alba-Iulia, 2012

Gh. Popilian, D. Bondoc, Așezările daco-romane de la Locusteni, Craiova 2014

D. Protase, Autohtonii în Dacia, București, 1980

D. Protase, Obreja. Aşezarea şi cimitirul daco-roman. Secolele II-IV. Dovezi ale continuitătii în Dacia, Cluj-Napoca, 2002

A. Pauly, G. Wissowa, Real Encyclopedie der Klassichen Altertumswissenschaft, Stuttgart, 1893 sqq.

Roman Imperial Coinage, vol. II-IV

I. A. Richmond, The Plans of Roman Villas in Britain, în A. L. F. Rivet (ed.), The Roman Villa in Britain. Study in Ancient History \& Archaeology, Londra, 1969, p. 49-70

A. L. F. Rivet, Social and Economic aspects, în A. L. F. Rivet (ed.), The Roman Villa in Britain. Study in Ancient History \& Archaeology, Londra, 1969 , p. $173-216$

Römer in Rumänien. Ausstehlung des Römisch-Germanischen Museums Köln und des Histrorischen Museums Cluj (Kunsthall Köln, 12. Februar bis 18. Mai 1969), 1969

Viorica Rusu Bolindeț, Ceramica romană de la Napoca; Contributii la studiul ceramicii din Dacia romană, Cluj-Napoca, 2007

J. T. Smith, Roman Villas. A Study in Social Structure, Londra - New York 2002

Z. Székely, Villa rustica de la Ciumăfaia, Studii şi Comunicări (Sibiu), 14, 1969, p. 155-181

Edith B. Thomas, Römische Villen in Pannonien: Beiträge zur pannonischen Siedlungsgeschichte, Budapest, 1964

C. van Tilburg, Traffic and con gestion in the Roman Empire, Londra - New York, 2007

S. Soproni, Tabula Imperii Romani, Karte des Römischen Reiches auf der Grundlage der internationalen Karte 1:1000000. L 34 - Aquincum, Sarmizegetusa, Sirmium, Amsterdam, 1968

D. Tudor, Oraşe, târguri şi sate în Dacia romană, Bucureşti, 1968

D. Tudor, Oltenia romană, Bucureşti, ediția a IV-a, 1978

Lucia Teposu Marinescu, Funerary Monuments in Dacia Superior and Dacia Porolissensis, BAR International Series 128, 1982

Iudith Winkler, Matilda Takács, Gh. Păiuș, Așezarea dacică şi daco-romană de la Cicău, Apulum, 17, 1979, p. 129-193 
Winkler et alii 1968

Winkler, Blăjan 1993

Wollmann 1970

Wollmann 1975 ludith Winkler, V. Vasiliev, I. Chitu, A. Borda, Villa rustica de la Aiud. Cîteva observaţii privind villae-le rusticae din Dacia Superior, Sargetia, V, 1968, p. $59-85$

Iudith Winkler, M. Blăjan, Așezările rurale romane de la Mediaş (jud. Sibiu), ActaMN, 26-30, I/2, 1989-1993, p. 459-476

V. Wollmann, Materiale epigrafice şi sculpturale romane în Muzeul Sebeș, $\operatorname{ActaMN}, 7,1970$, p. 163-183

V. Wollmann, Gernmanische Volks und Kulturelemente im römischen Dakien, Germania, 53, 1975, p. 166-174

\section{LIST OF ILLUSTRATIONS}

PI. I 1. Location of site Tărtăria II; 2. General bird's-eye view of the plateau where the site Tărtăria II is located; 3. Aerial photo of the investigated area

PI. II 1. Motorway Orăştie - Sibiu, sector 1. The archaeological site Tărtăria II $-\mathrm{km} 15+100-15+300$.

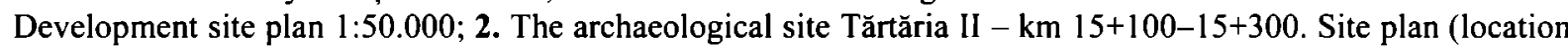
on ortophotomap)

PI. III 1. General layout of the archaeological excavations - investigated excavation units (including trenches), location on ortophotomap; 2. Graphic representation of the main cross-sections (general stratigraphy of the site)

PI. IV The archaeological site Tărtăria II. General layout: 1. Chronological and cultural frame of reference of the investigated complexes; 2 . Complexes dating to the Roman period

PI. V The archaeological site Tărtăria II. The Roman period: 1. Phase 1; 2. Phase 2

PI. VI 1. Aerial photo of the archaeological site Tărtăria II, on an intermediary stage of research, with the outline of the edifices; 2. Edifice E4 - general layout

Pl. VII Complex 1: 1. Ground plan and cross-section; 2. Image during the excavation

PI. VIII Edifice E1: 1. General layout; 2. Detail on the SE corner before the dismantling of the debris level, view from West

PI. IX 1. Edifice E1 - aerial general photo, after the dismantling of the colappsed roof; 2. Edifice El and Complexe 35, after the dismantling of the level with roof tiles

PI. X Edifice E2: 1. General layout; 2. Edifice E2 and Edifice E4, view from North

PI. XI Edifice E3: 1. General layout; 2. General bird's-eye view from West

PI. XII 1. Complexe 22, ground plan and cross-section; 2. Complexe 24, ground plan and cross-section; 3. Complexe 10, ground plan; 4. Complexe 4, ground plan and cross-section; 5. Edifice E5, the investigated area PI. XIII 1. Edifice E2, Edifice E3, Edifice E4 - aerial view; 2. Detail on the debris level corresponding to Edifice E5

PI. XIV Archaeological finds from Tărtăria II (Cat. nos. 1-9)

PI. XV Archaeological finds from Tărtăria II (Cat. nos. 10-20)

PI. XVI Archaeological finds from Tărtăria II (Cat. nos. 21-31)

Pl. XVII Archaeological finds from Tărtăria II (Cat. nos. 32-39)

PI. XVIII Archaeological finds from Tărtăria II (Cat. nos. 40-45)

PI. XIX Archaeological finds from Tărtăria II (Cat. nos. 46-52)

PI. XX 1. Roman period structures on the middle Mureş valley (sector Vințu de Jos - Simeria). Proposal for the route of the Roman road on the river's left bank

MIHAELA SIMION, DECEBAL VLEJA, NICOLAE STOICA

Muzeul Naţional de Istorie a României, București mihaela.simion98@gmail.com,vdecebal@yahoo.com RADU PETCU, ANDREI HEROIU, FLORELA VASILESCU SC Vanderlayarheo SRL 



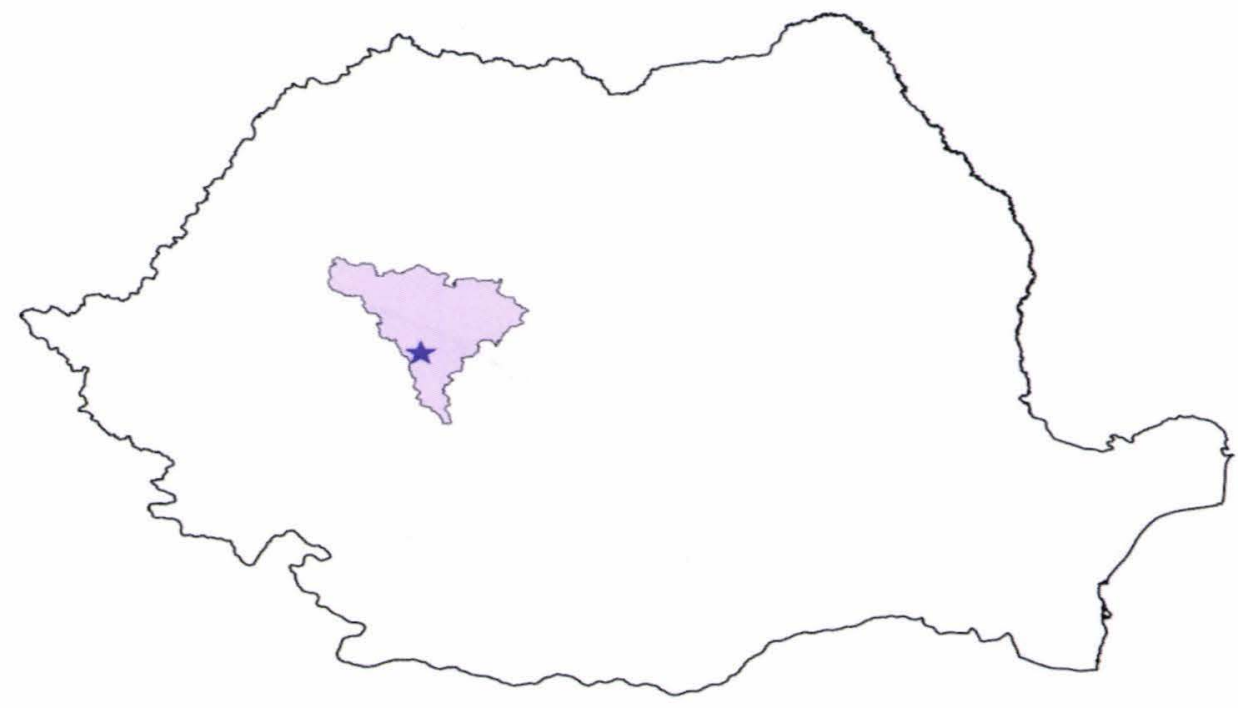

1.

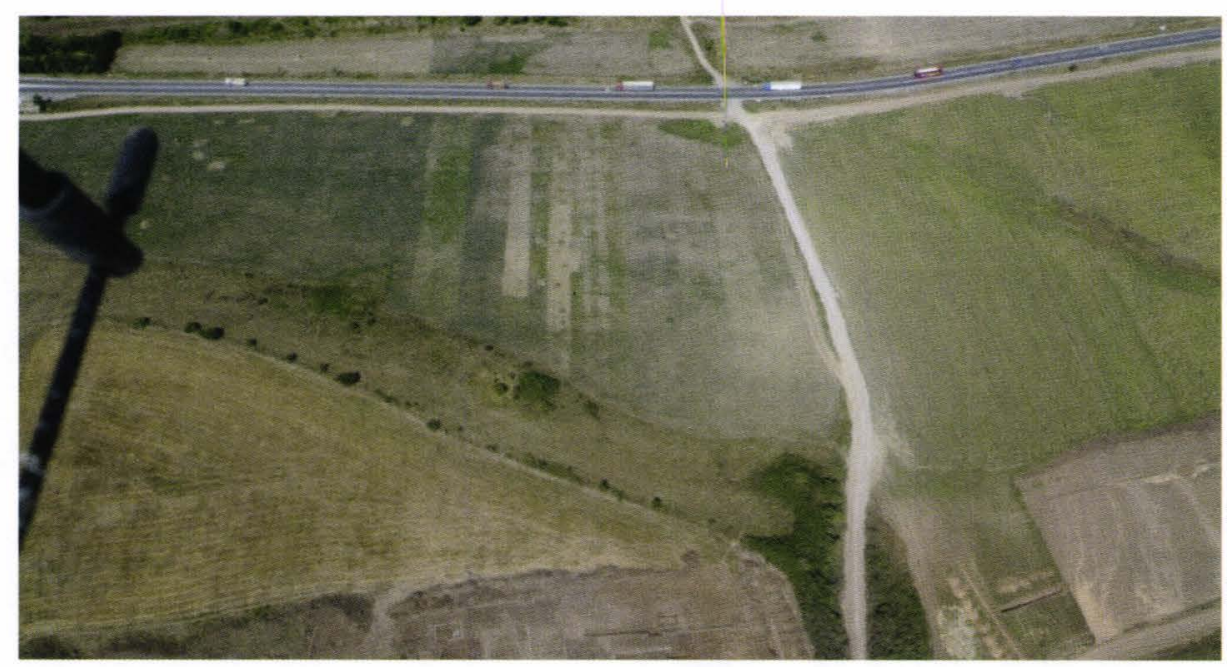

2.

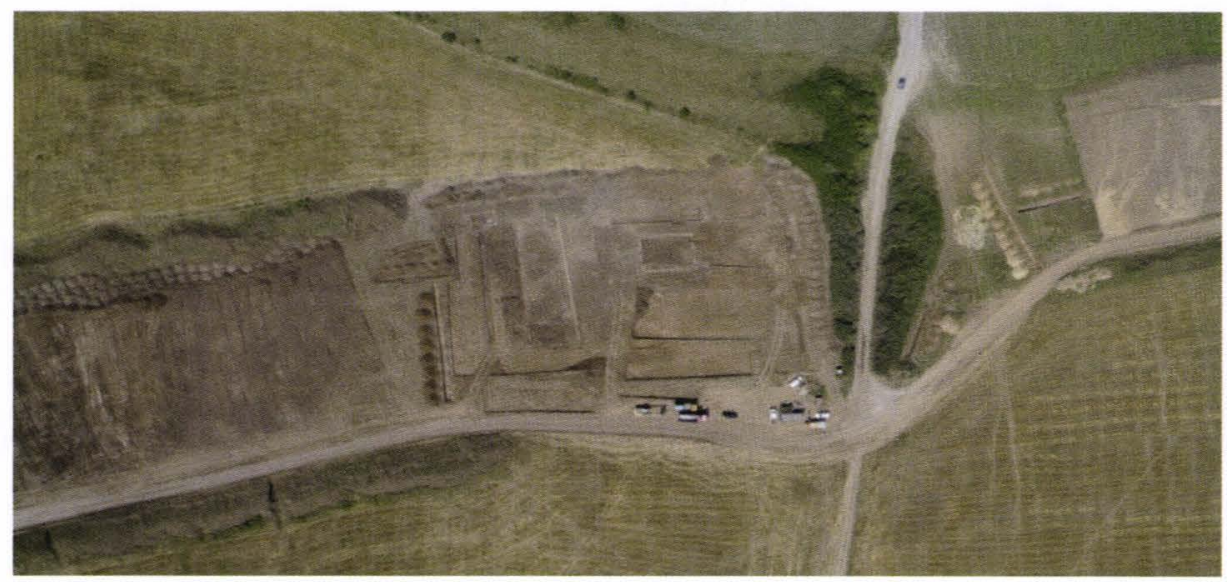

3.

1. Localizarea sitului de la Tărtăria II; 2. Imagine de ansamblu a platoului pe care este amplasat situl de la Tărtăria; 3. Fotografie aeriană a suprafeței investigate

\section{Pl. I}




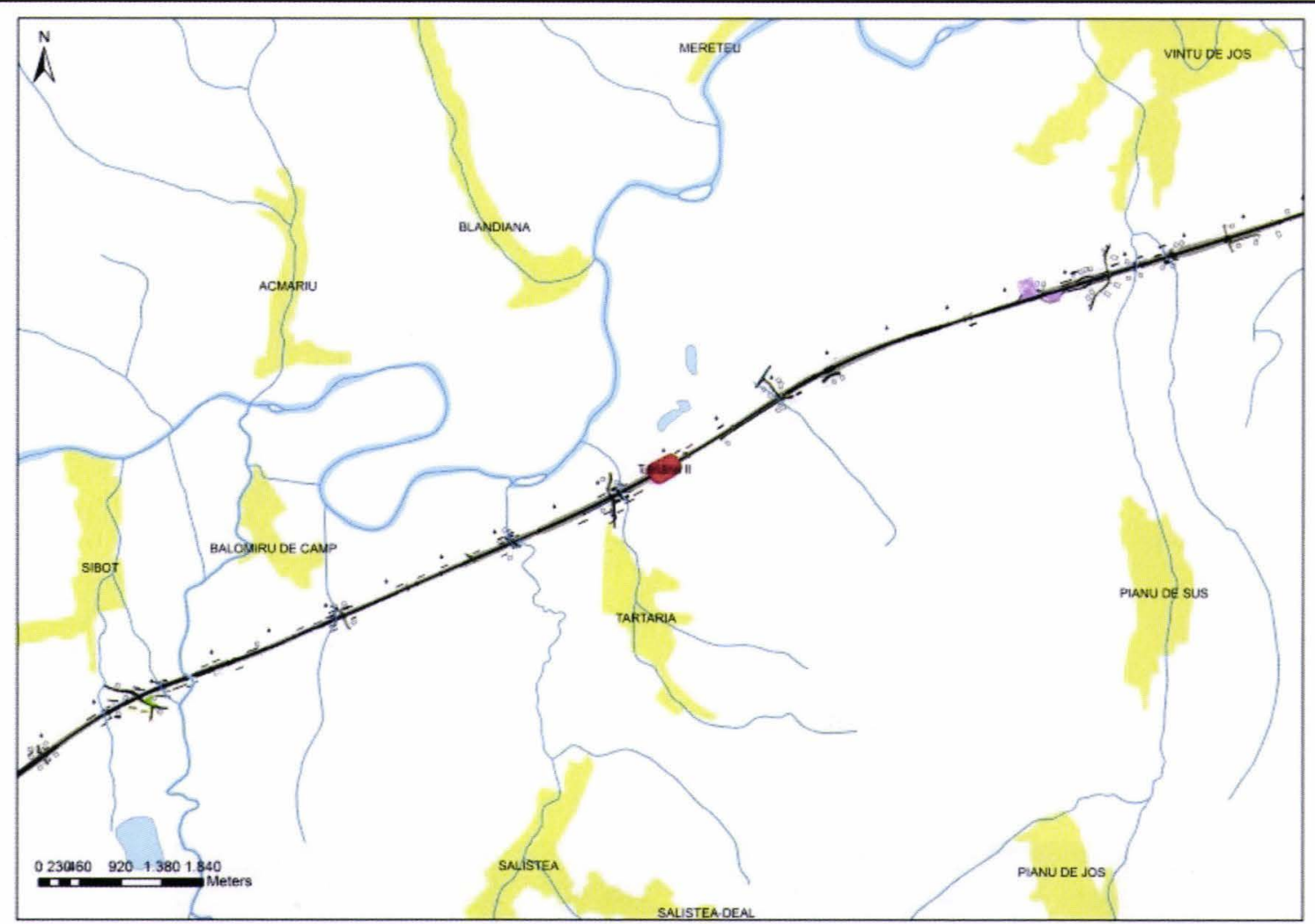

1.

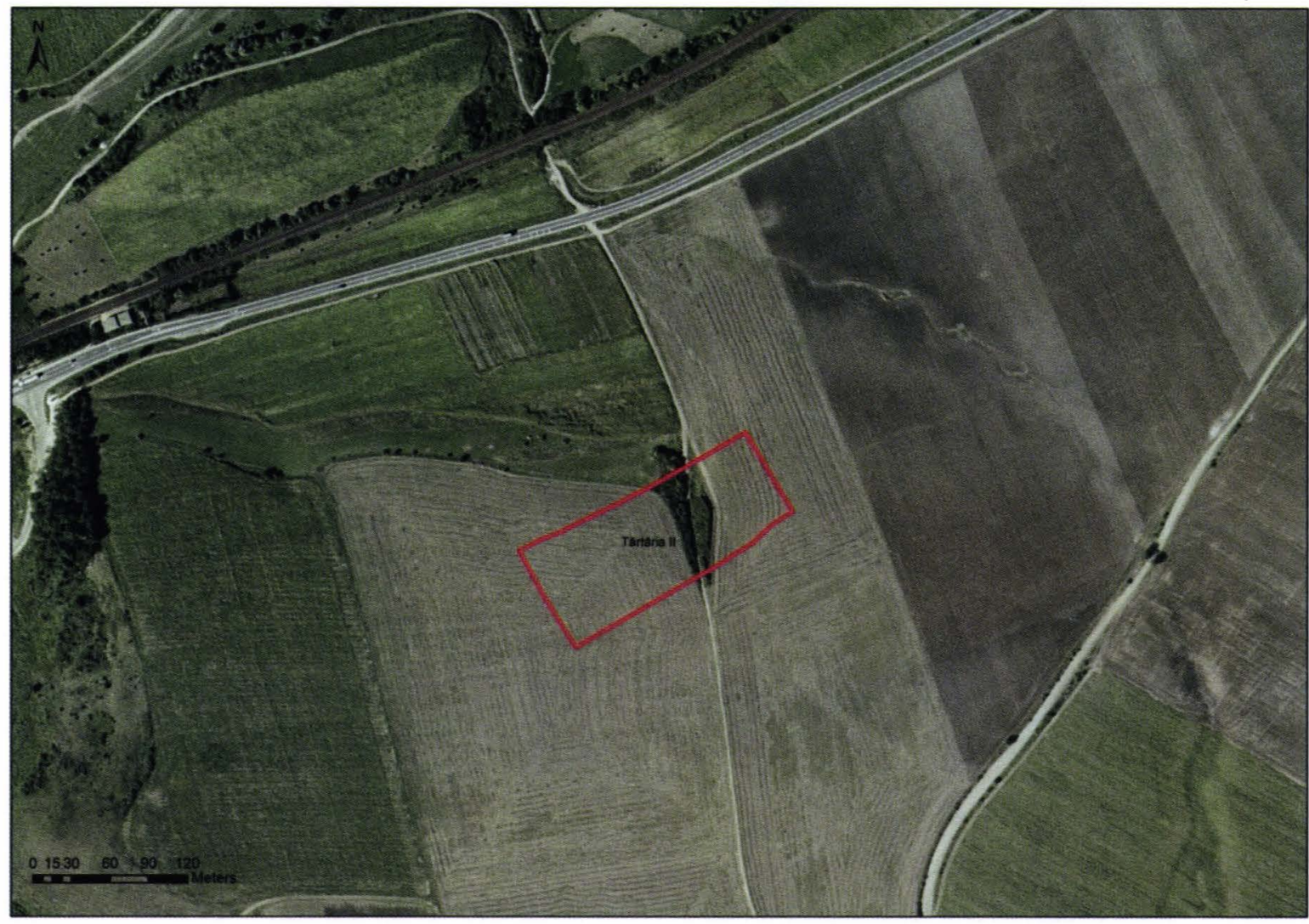

2.

1. Autostrada Orăștie - Sibiu, LOT 1 . Sit arheologic Tărtăria II, km 15+100-15+300. Plan de încadrare în zonă 1:50.000; 2. Situl Tărtăria II, km 15+100-15+300. Plan de situație (încadrare pe ortofotoplan) 


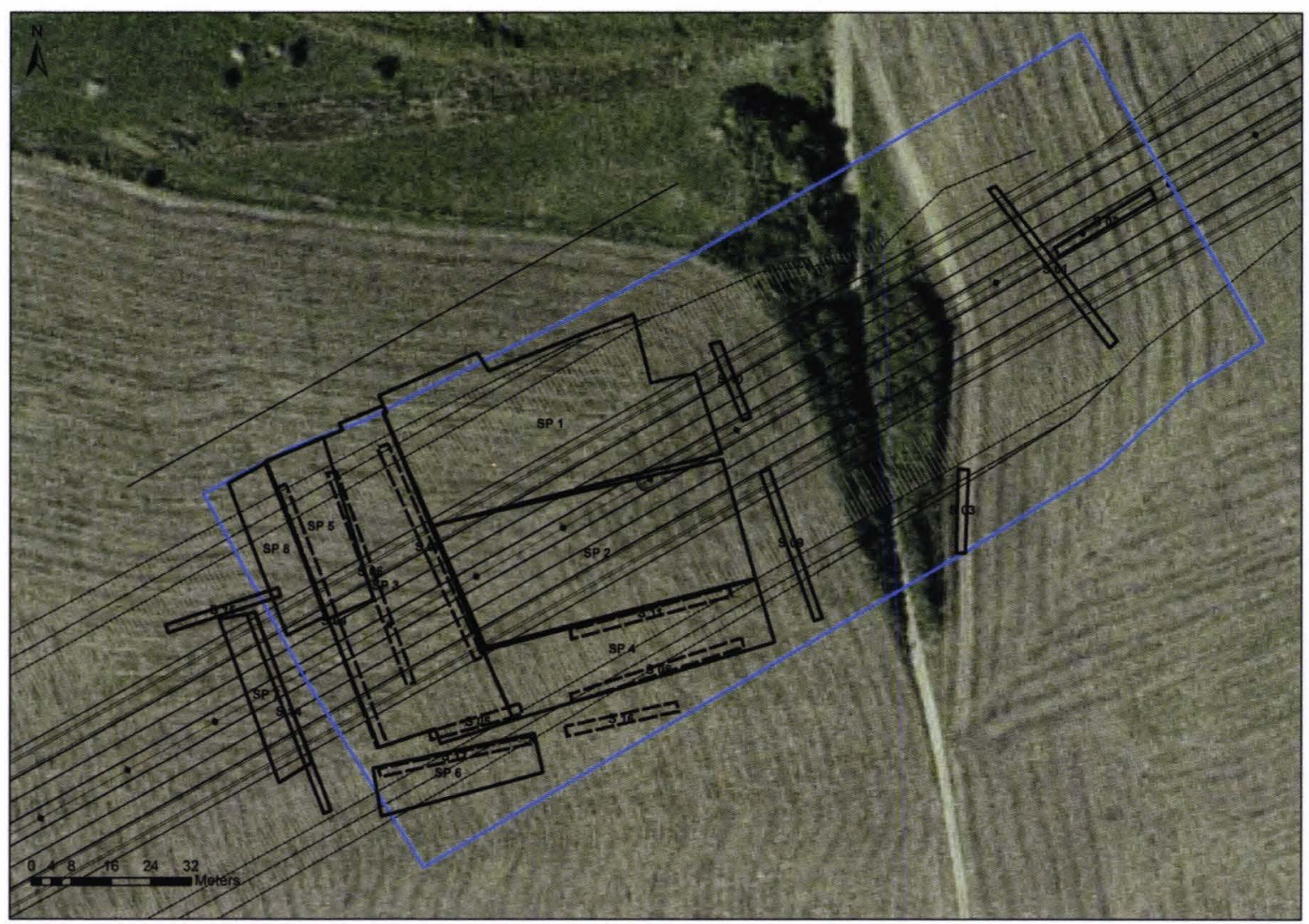

1.

Profil magistral pe axa $\mathrm{N}$ -

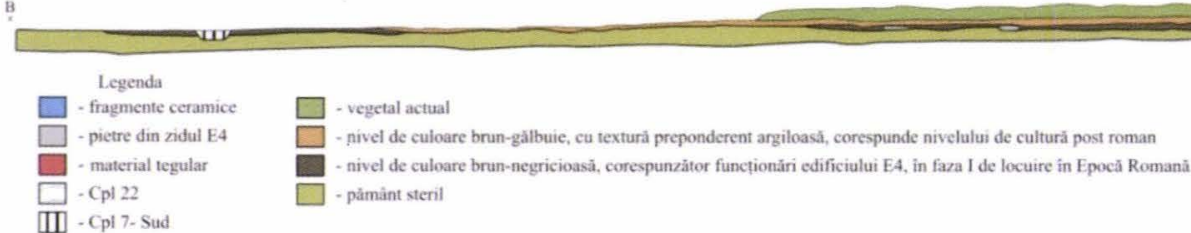

III - Cpl 7-Sud

Profil magistral pe axa N-S

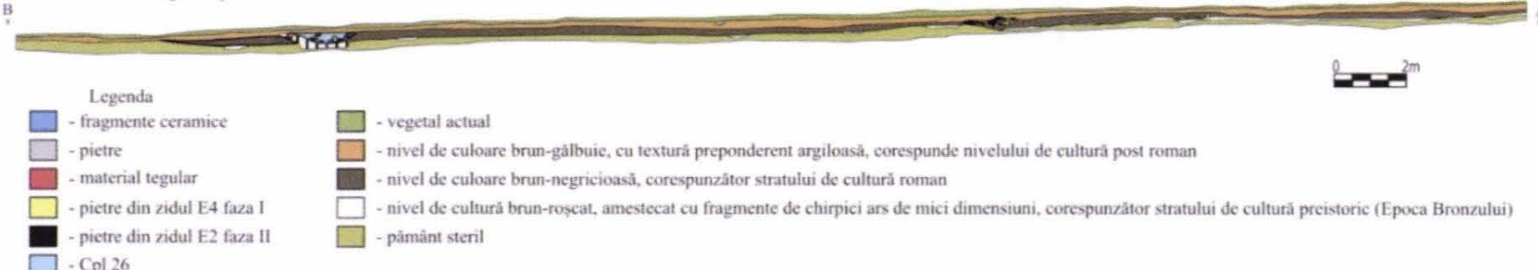

$\square \cdot \mathrm{Cpl} 26$

III - Cpt 7. Sud

Profil magistral pe axa V-H

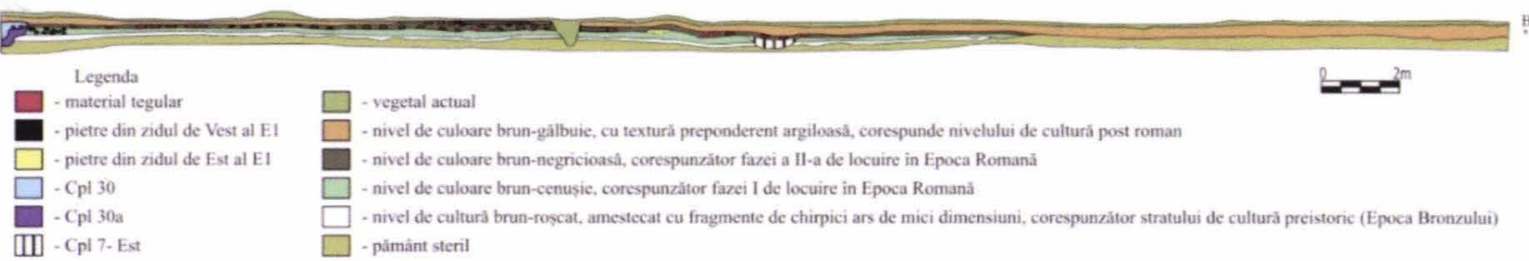

2.

1. Planul general al săpăturilor arheologice, secțiuni și suprafețe cercetate (încadrare pe ortofotoplan); 2. Reprezentarea grafică a profilelor magistrale (stratigrafia generală a sitului) 


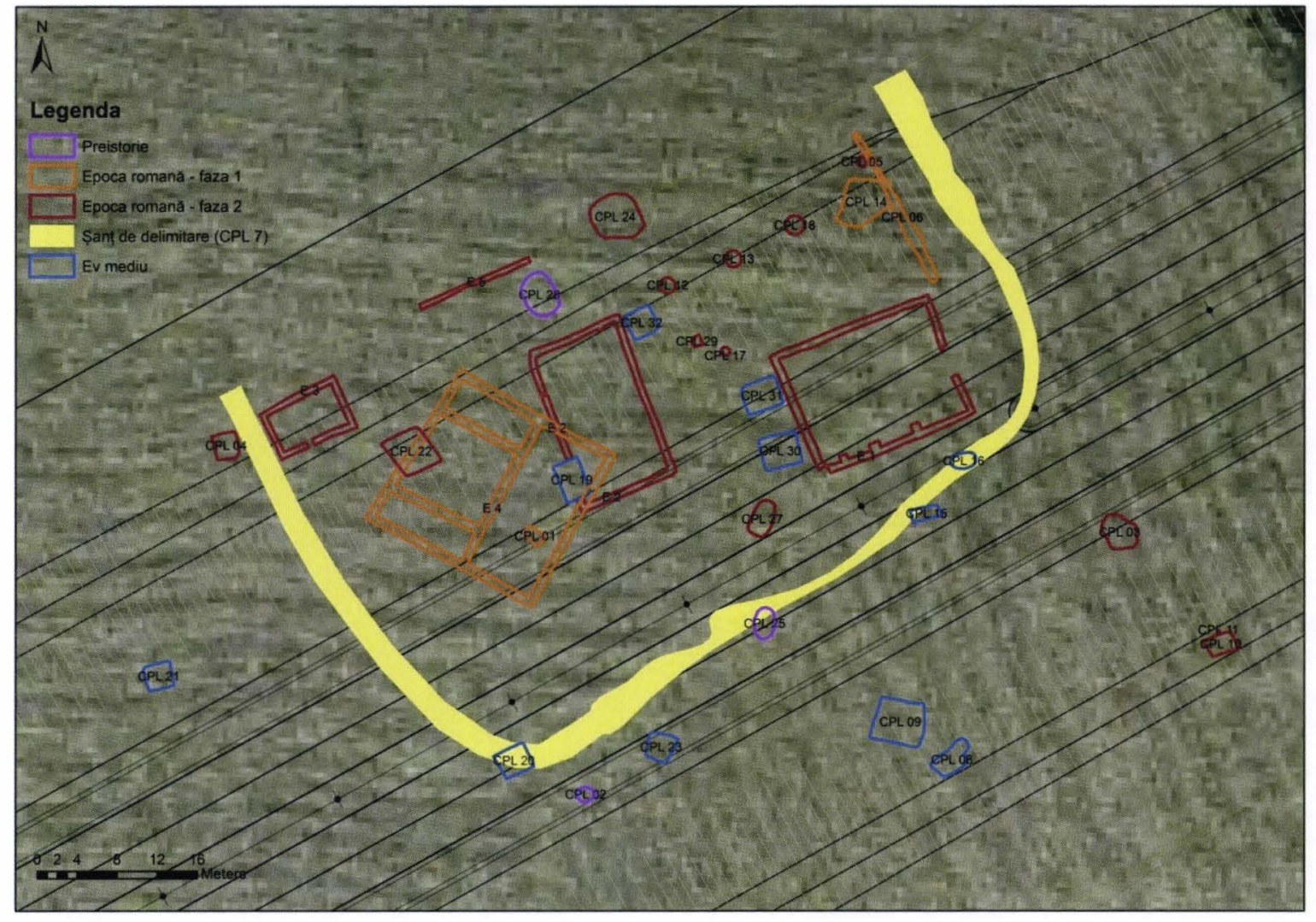

1.

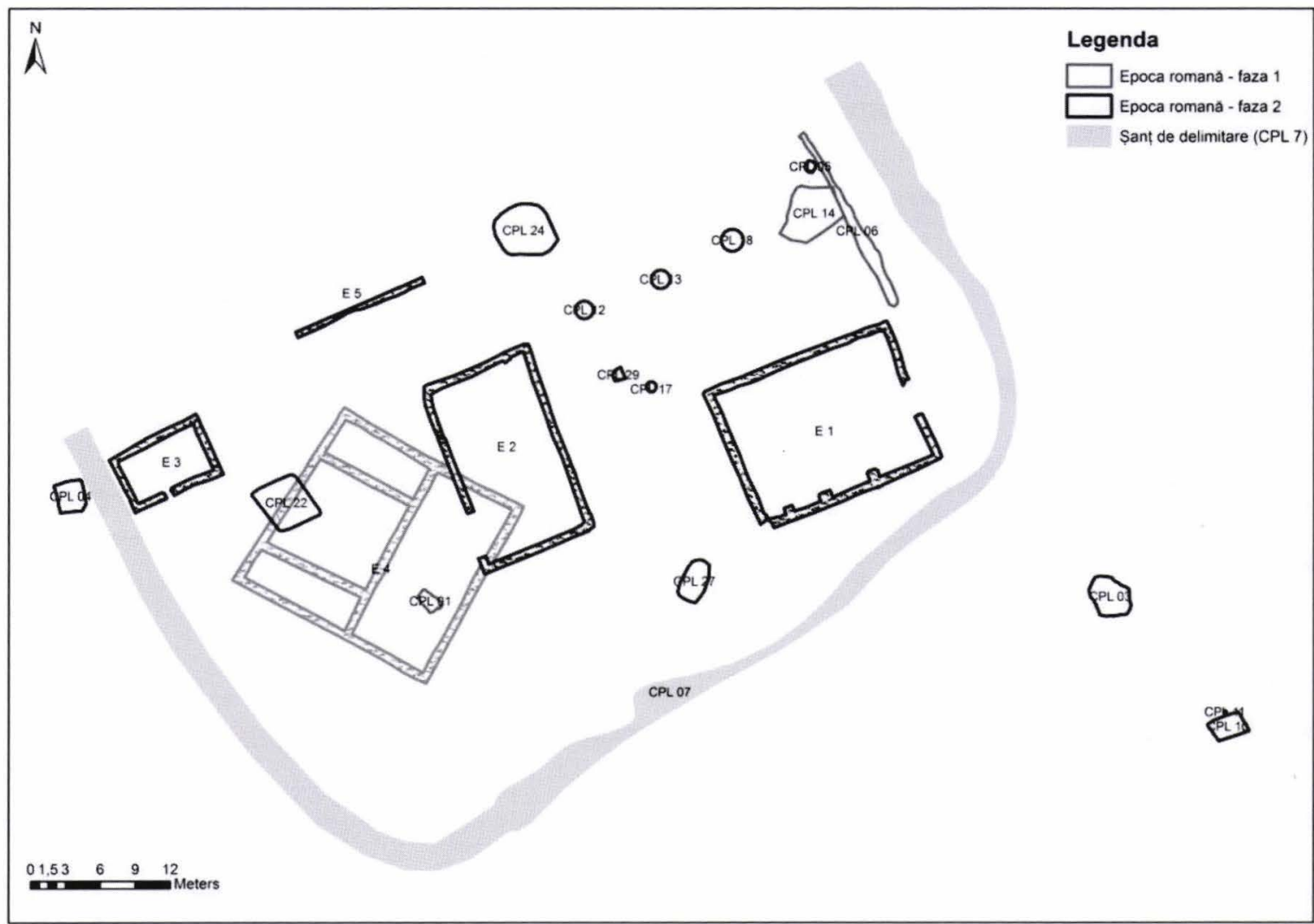

2.

Situl arheologic Tărtăria II. Plan general: 1. Încadrare cronologică și culturală a complexelor cercetate; 2. Complexe datate în epoca romană 


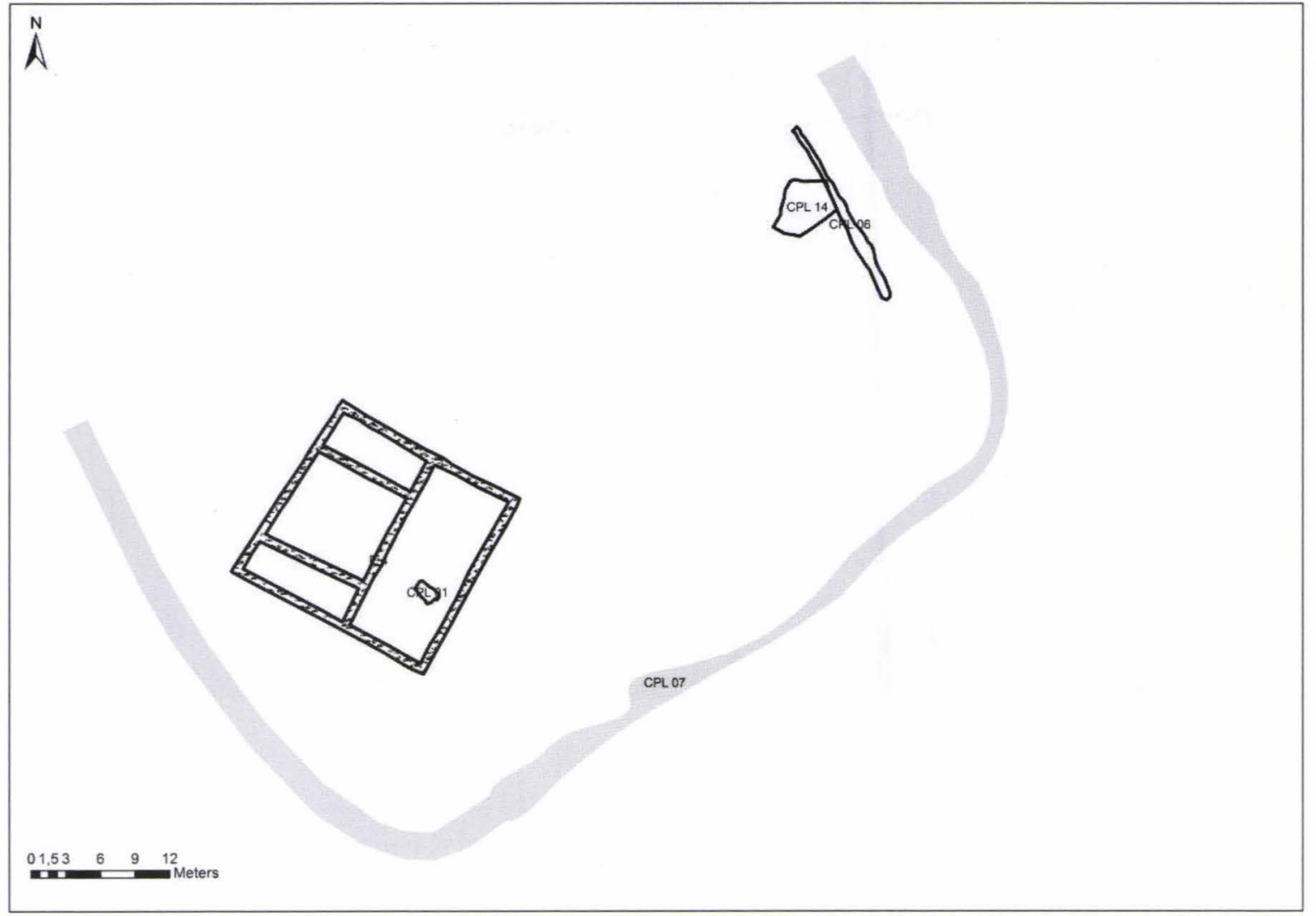

1.

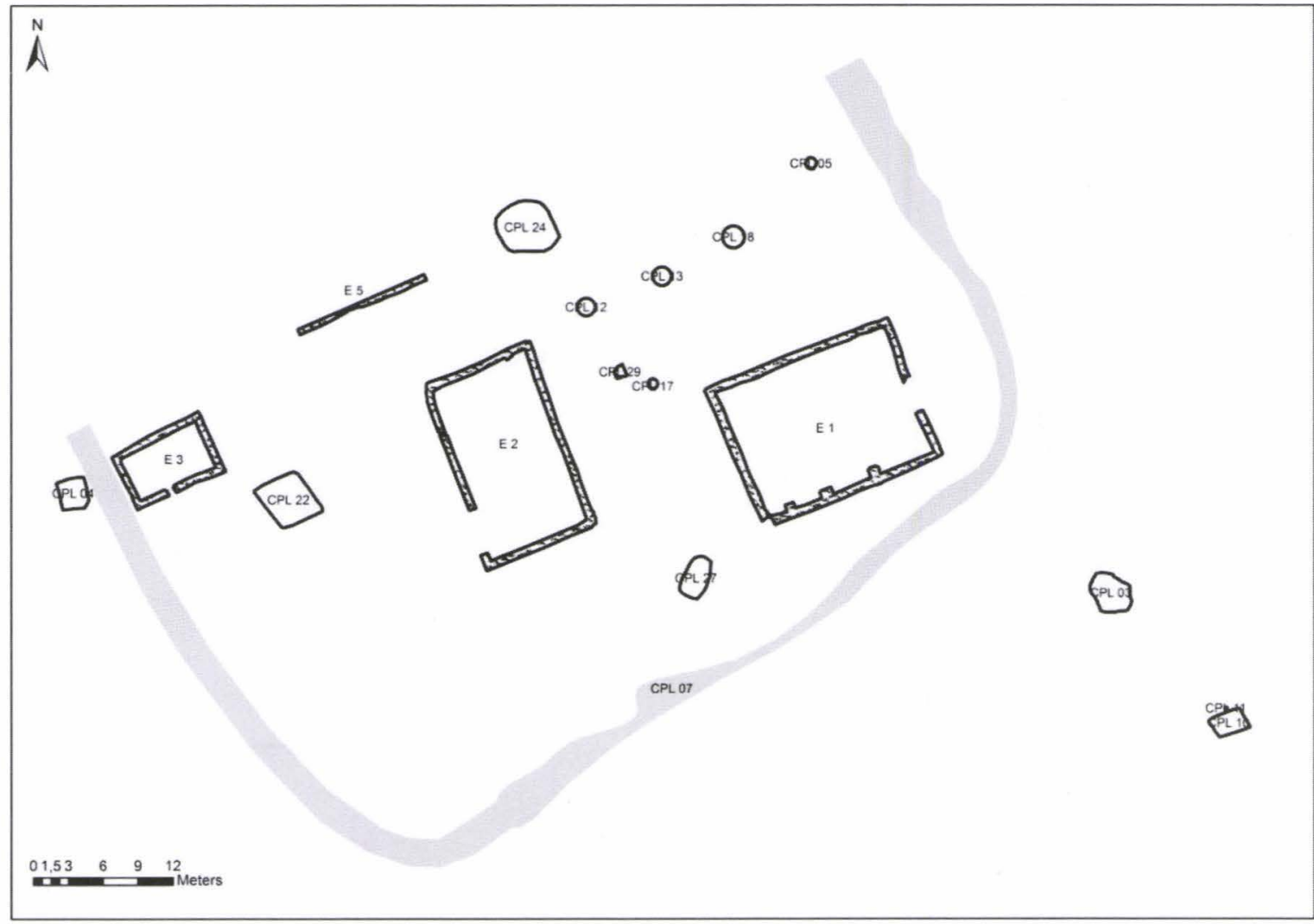

2.

Situl arheologic Tărtăria II. Epoca Romană: 1. Faza 1; 2. Faza 2

Pl. V 


\section{E 5}

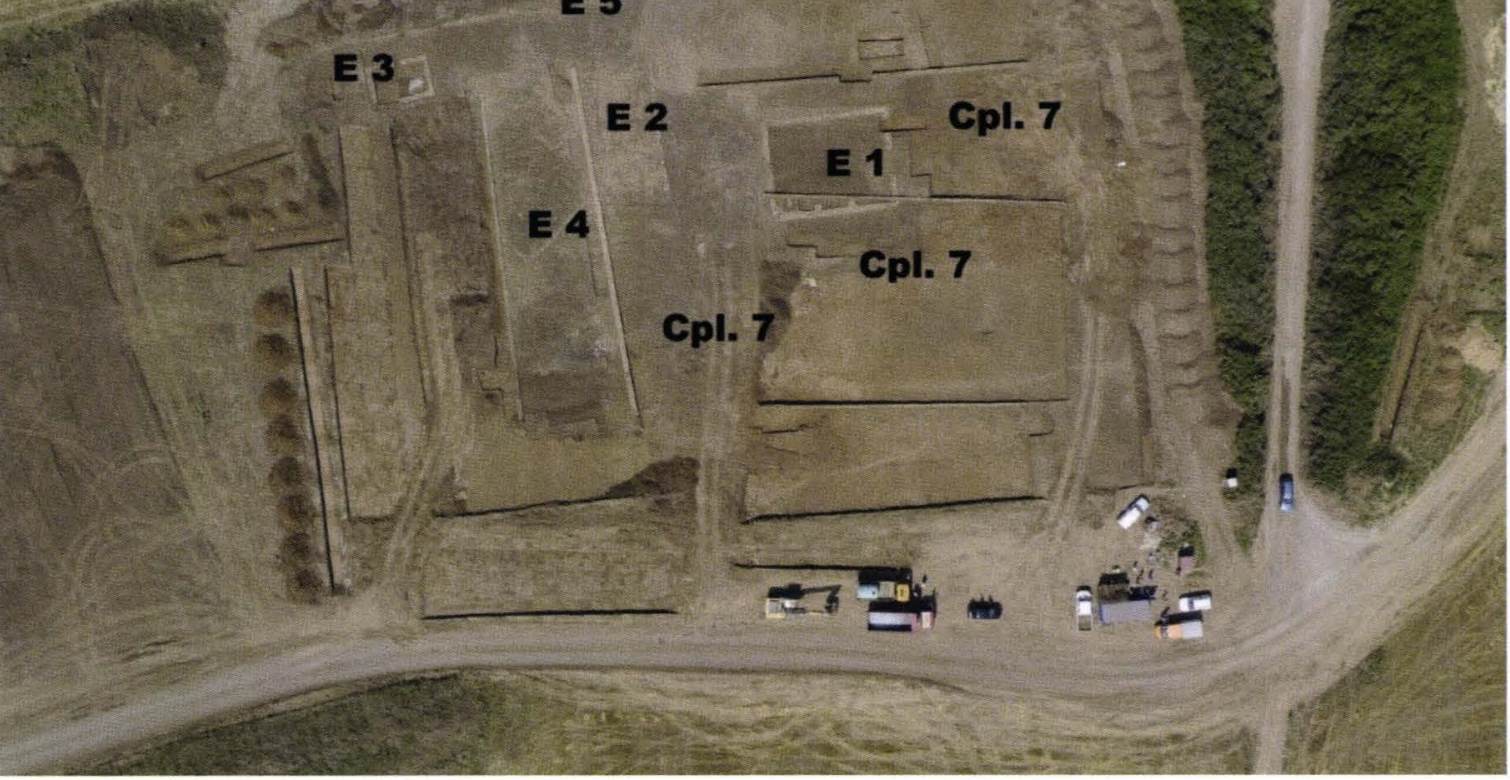

1.

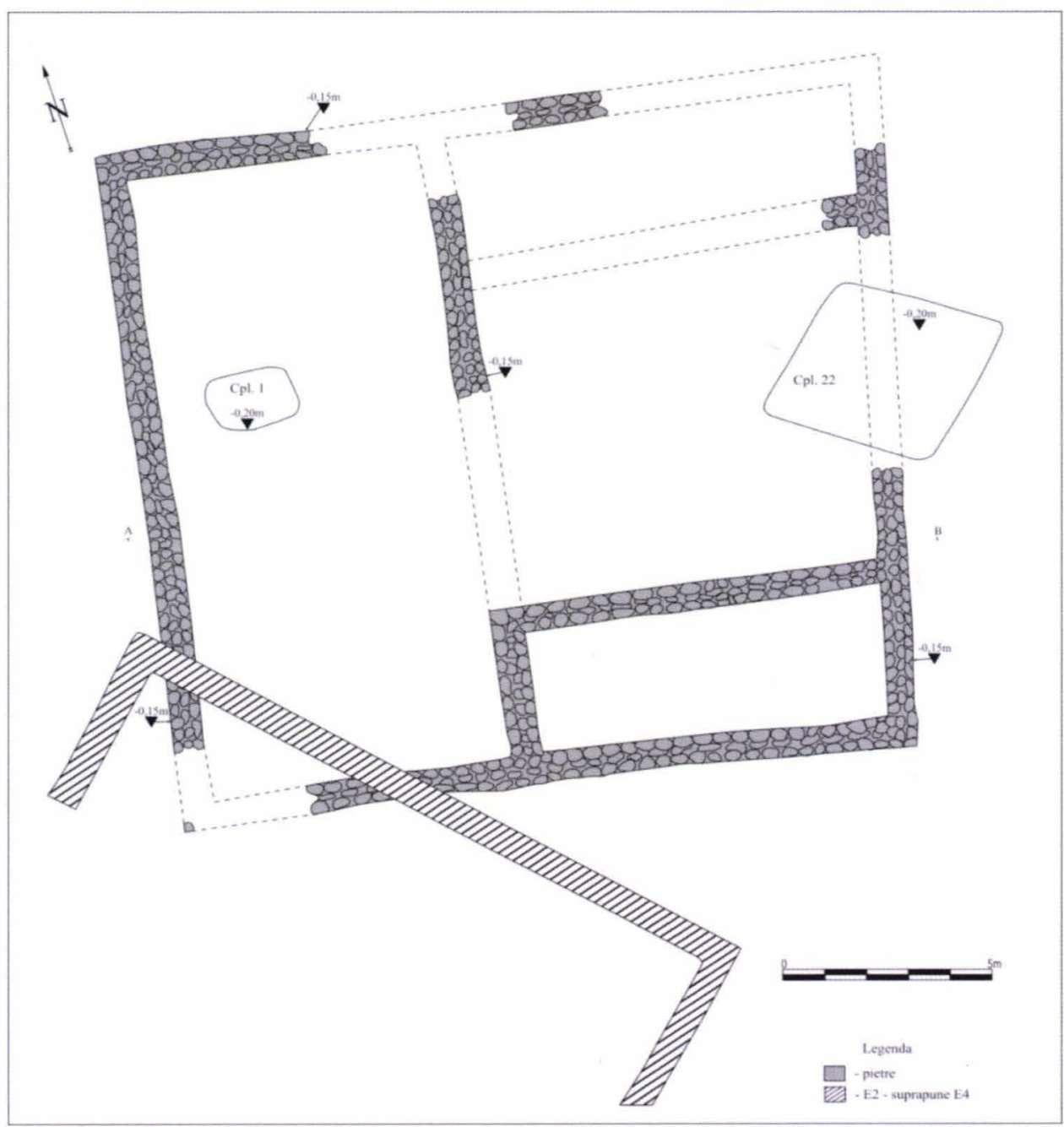

2.

1. Imagine aeriană a sitului Tărtăria II, în faza intermediară a cercetării, cu conturarea edificiilor; 2. Edificiul nr. 4, plan general 


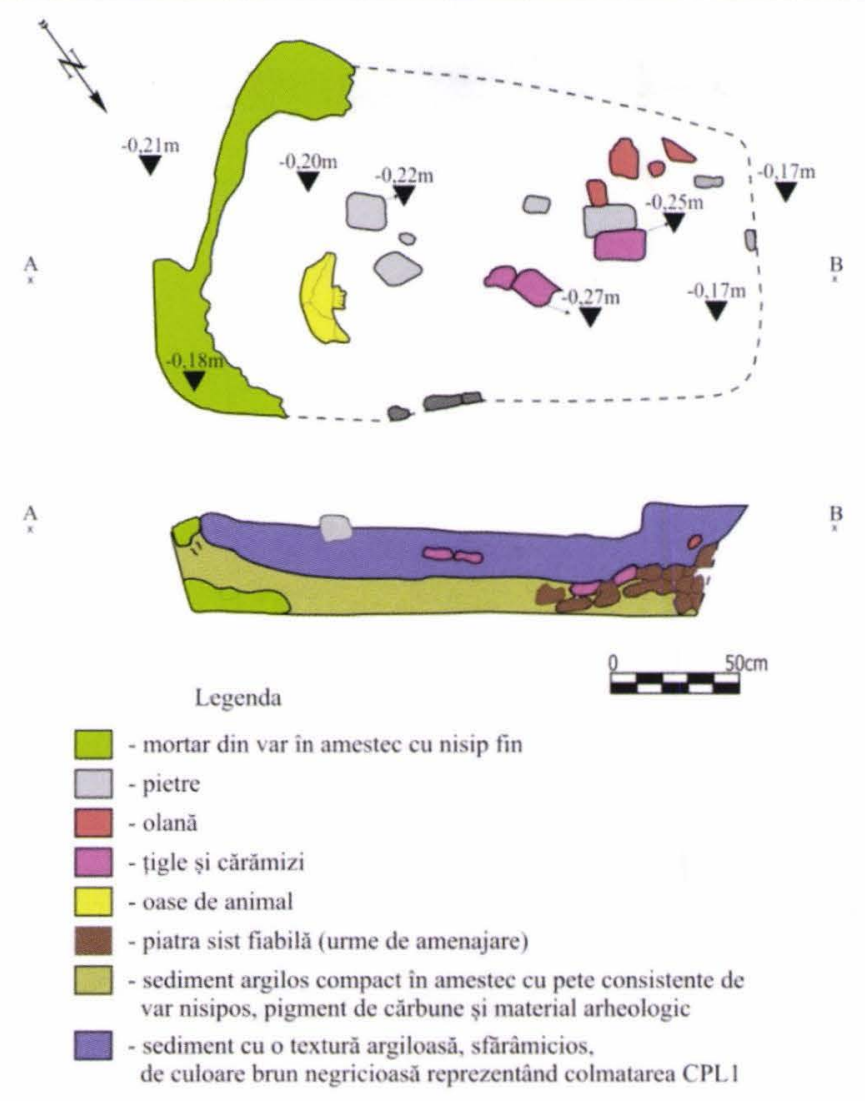

1.

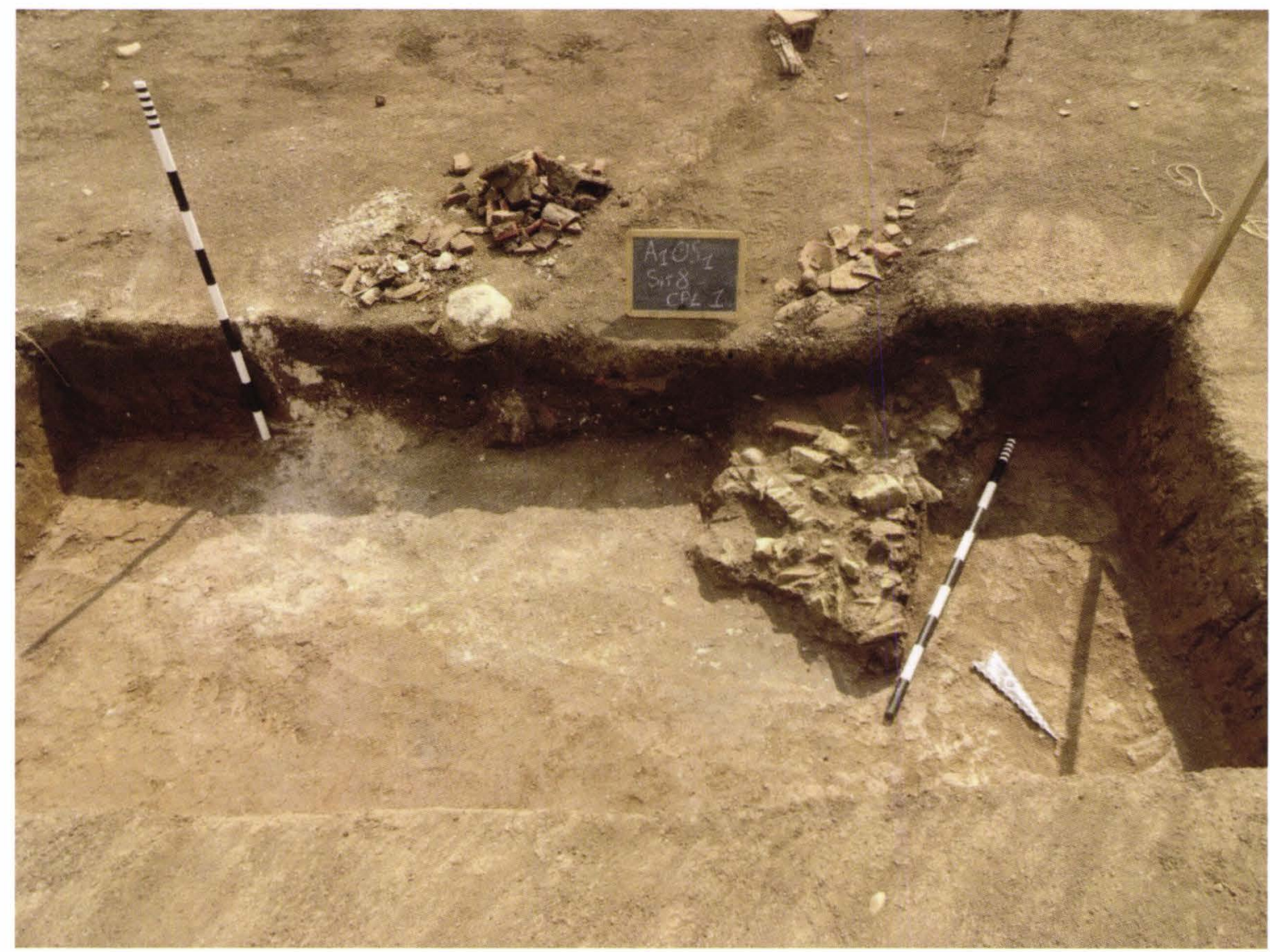

2.

Complexul 1: 1. Plan și secțiune transversală; 2. Imagine din timpul cercetării 


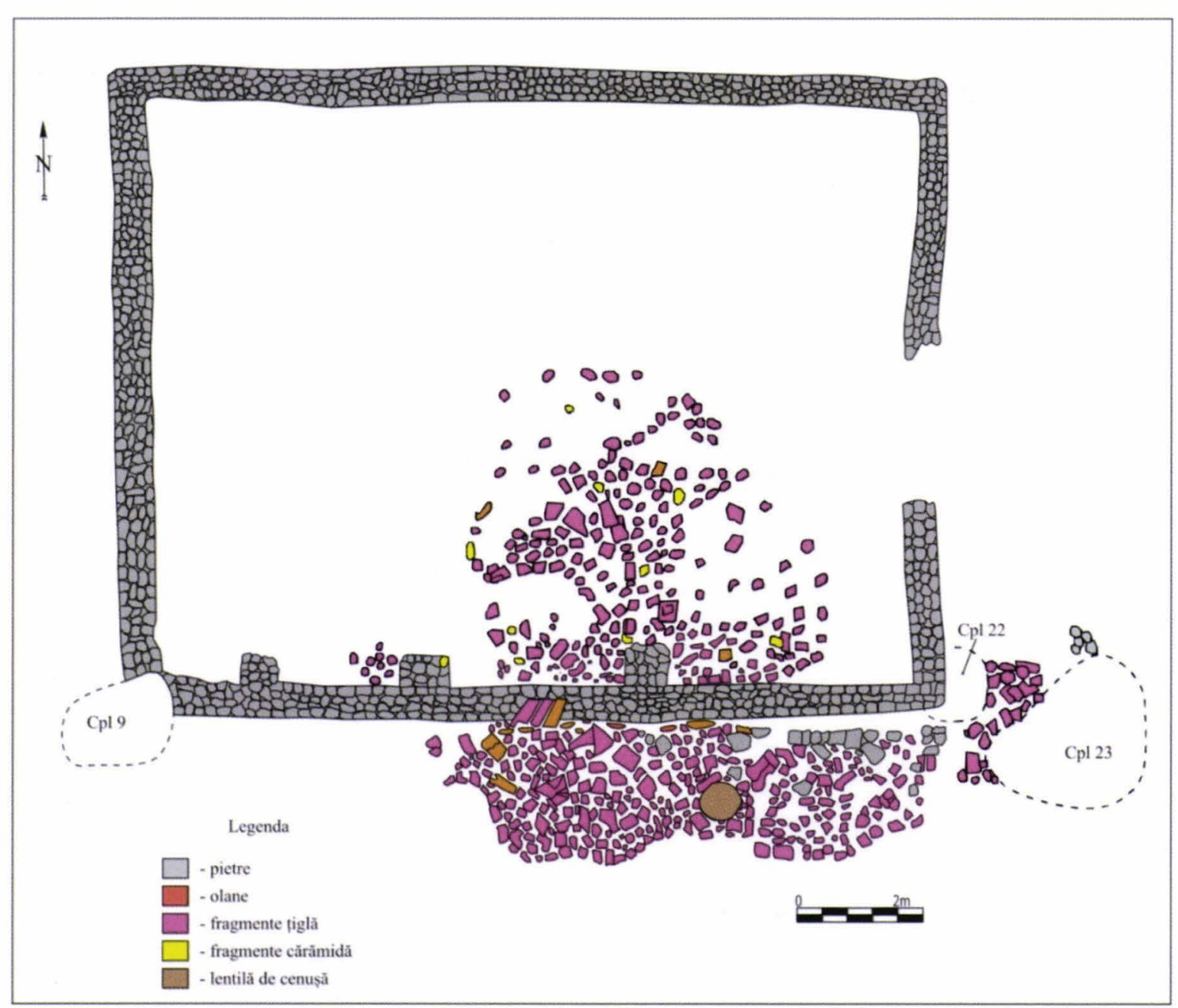

1.

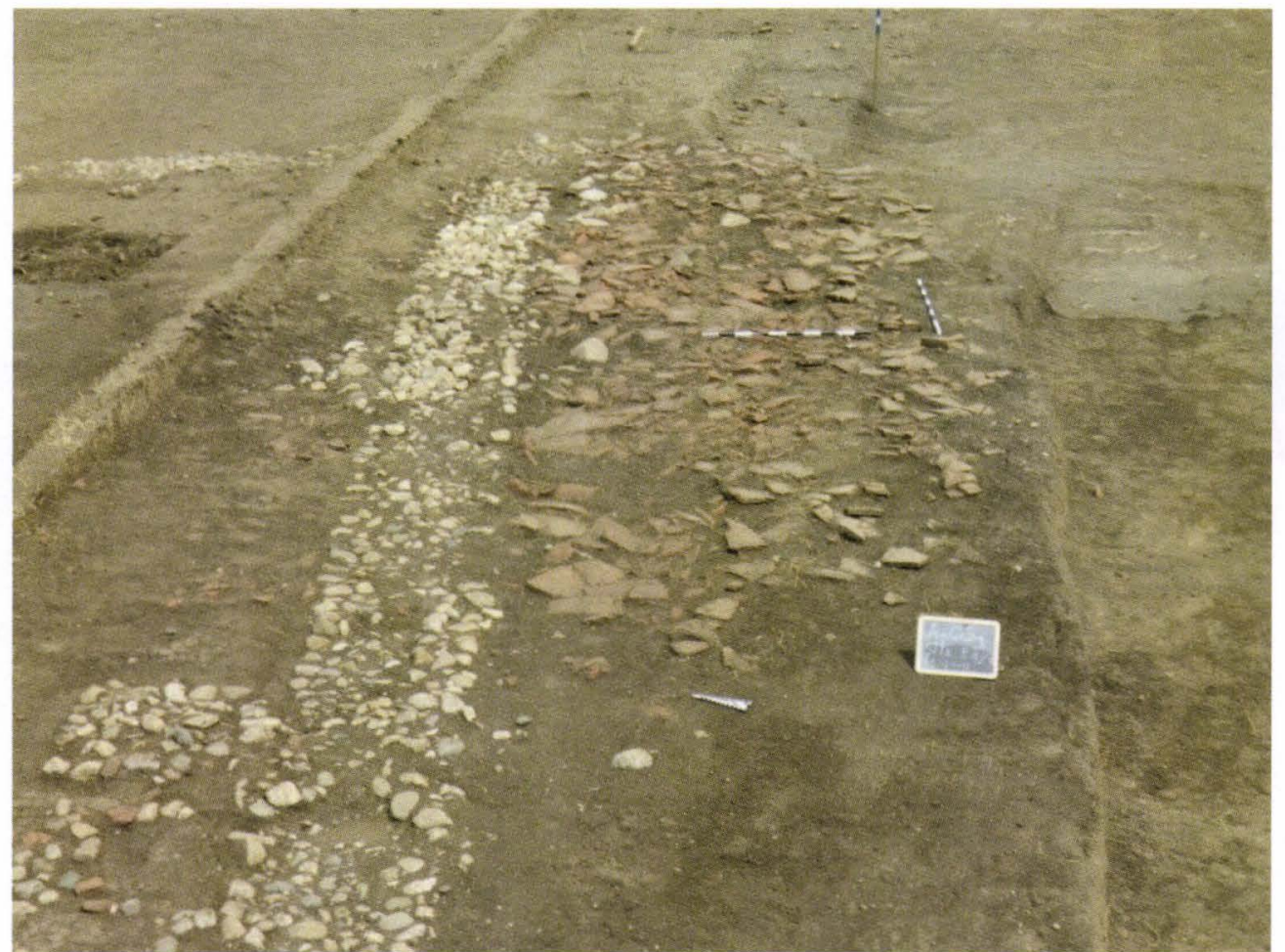

2.

Edificiul nr. 1: 1. Plan general; 2. Detaliu cu colțul de SE înainte de demontarea nivelului de dărâmătură, vedere dinspre vest 


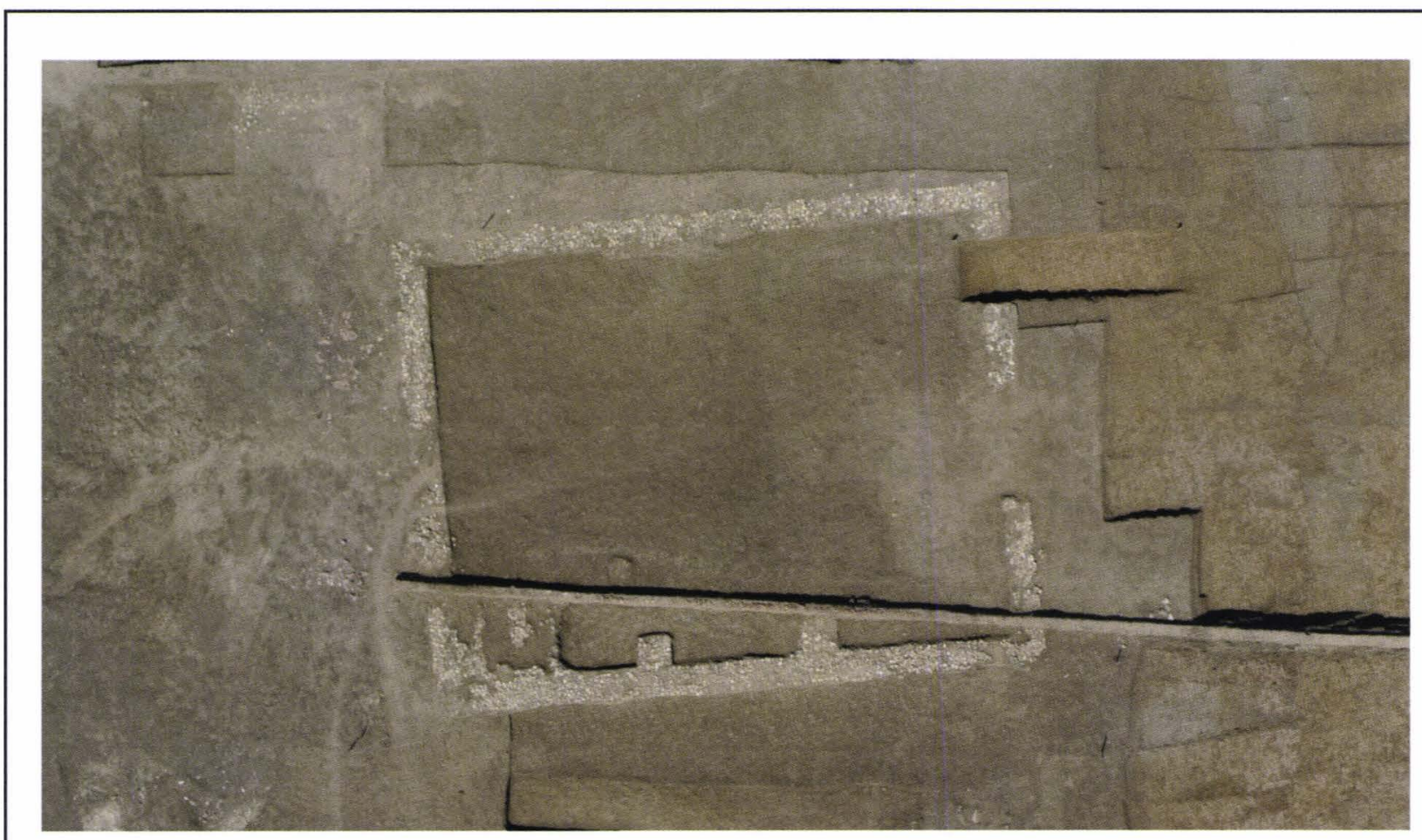

1.

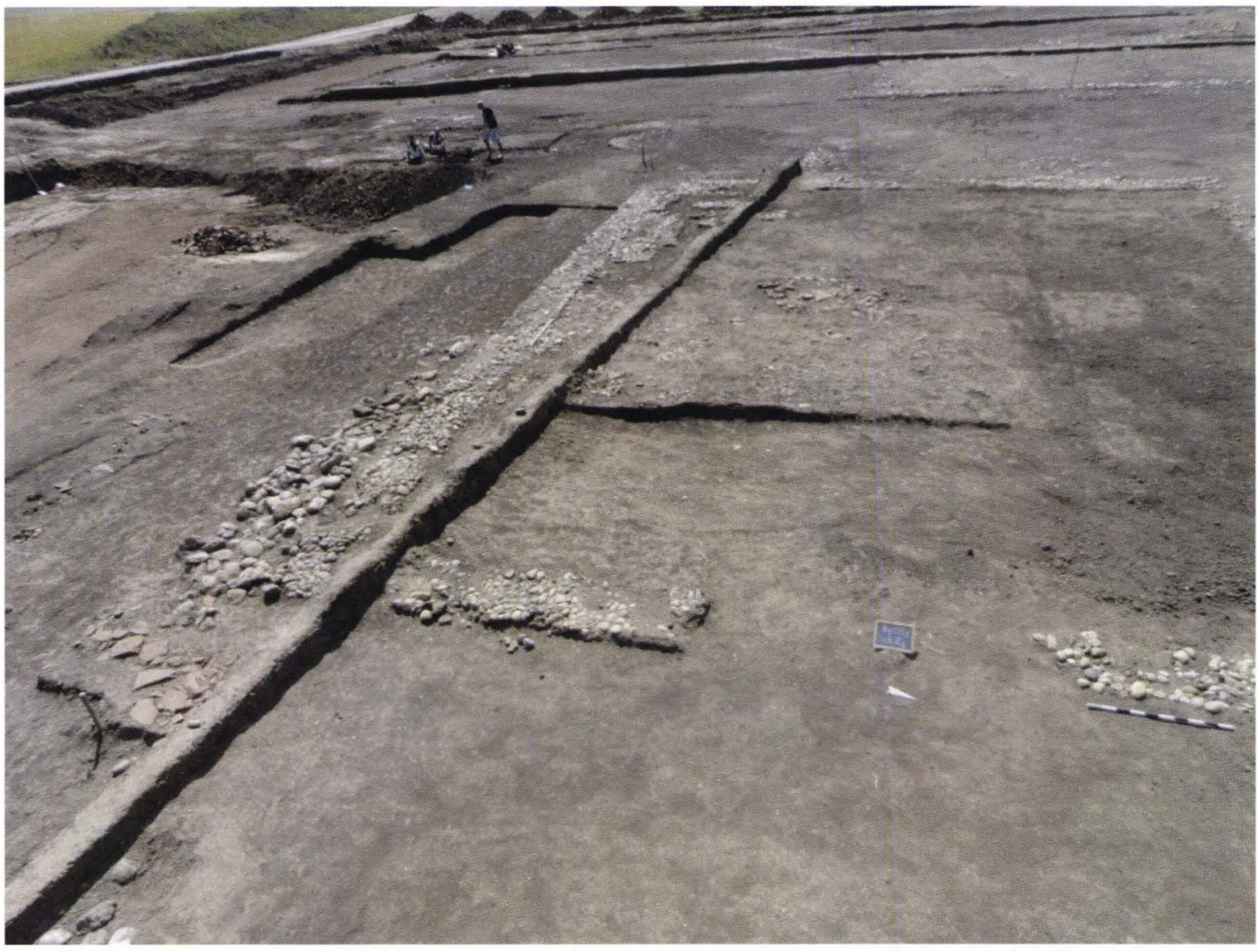

2.

1. Edificiul nr. 1 vedere generală aeriană, după demontarea acoperișului prăbușit; 2. Edifíciul nr. 1 și complexul 35, după demontarea nivelului de țigle și olane 


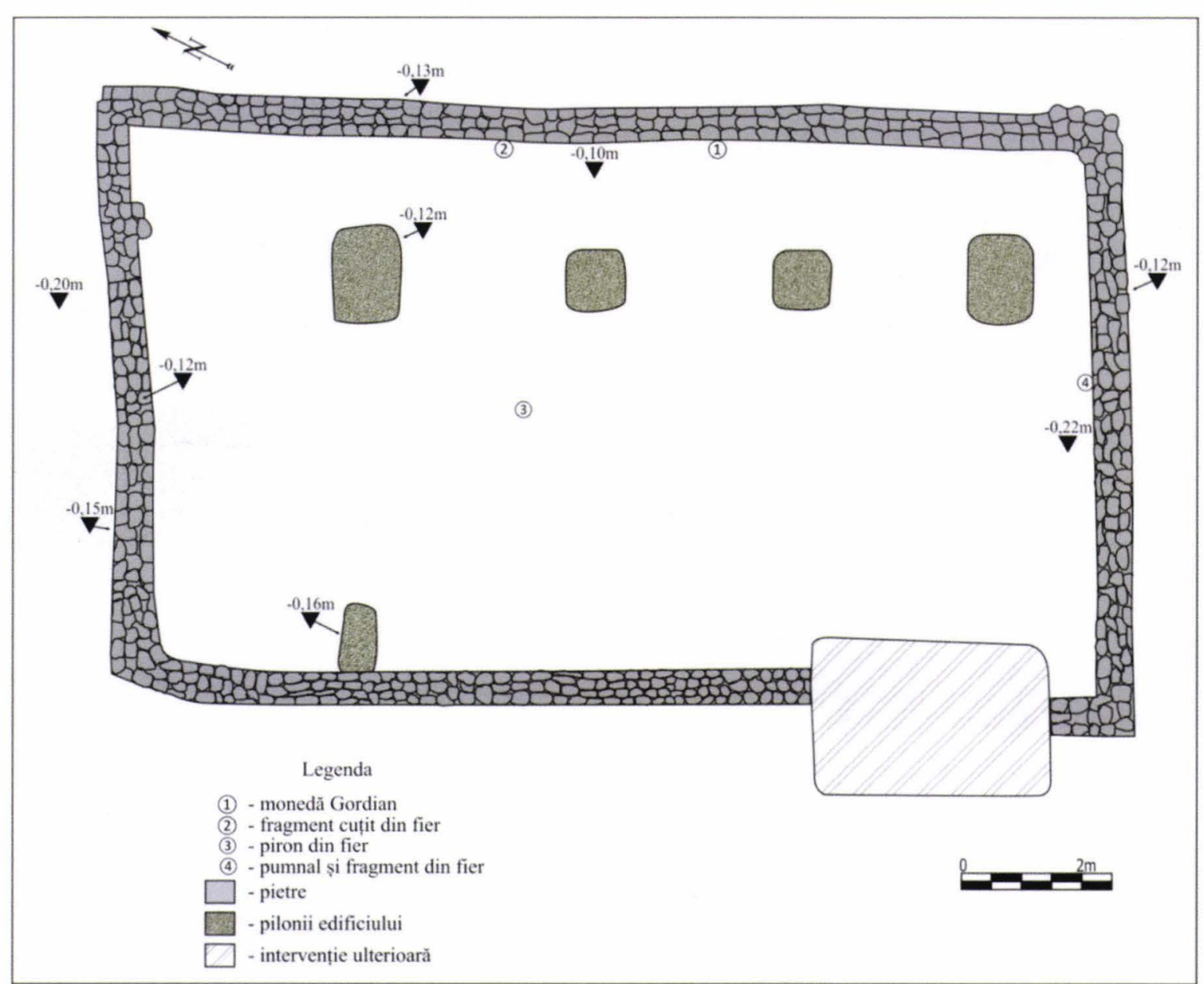

1.

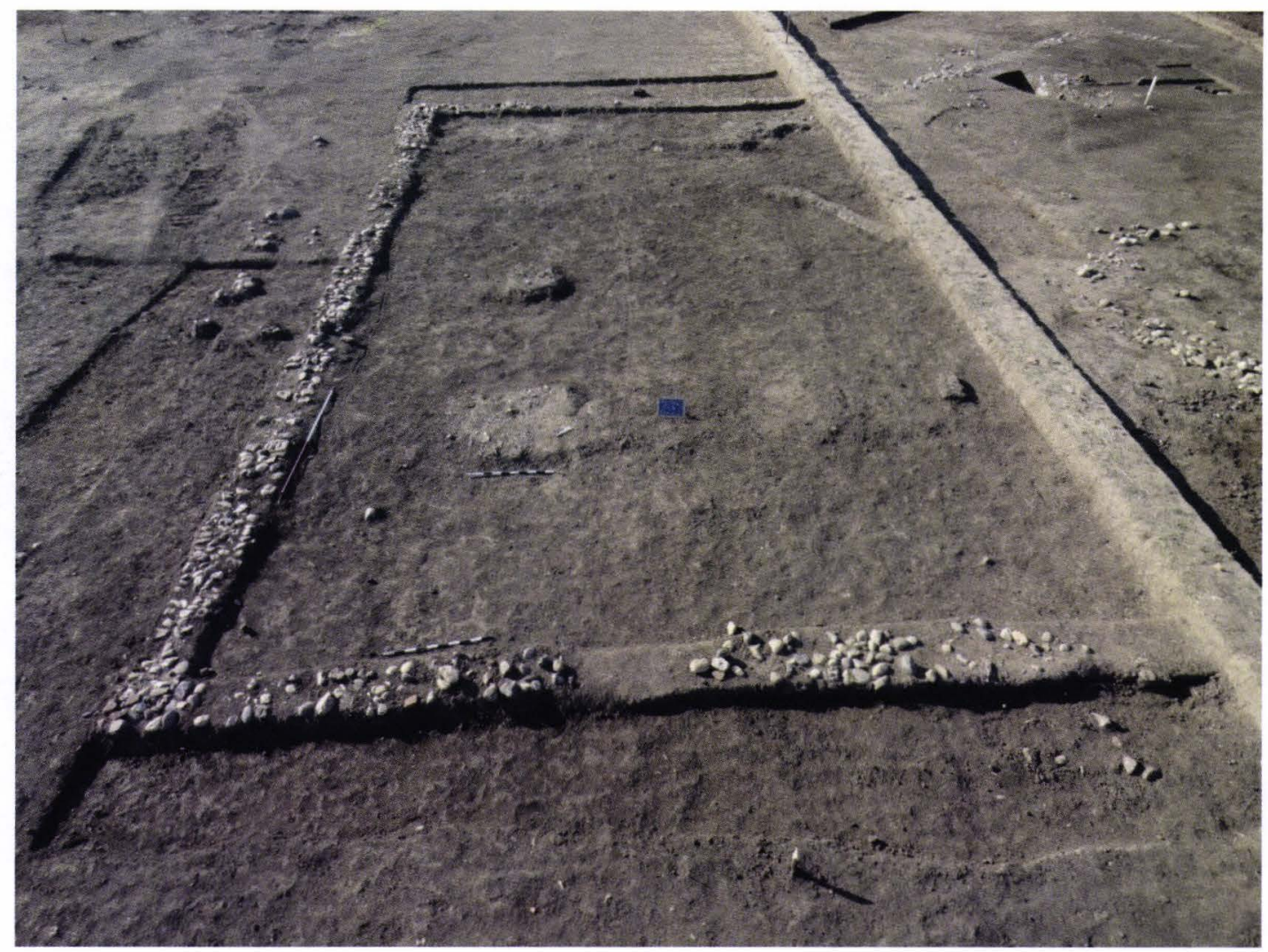

2.

1. Edificiul nr. 2: plan general; 2. Edificiul nr. 2 și Edificiul nr. 4, vedere dinspre nord

Pl. X 


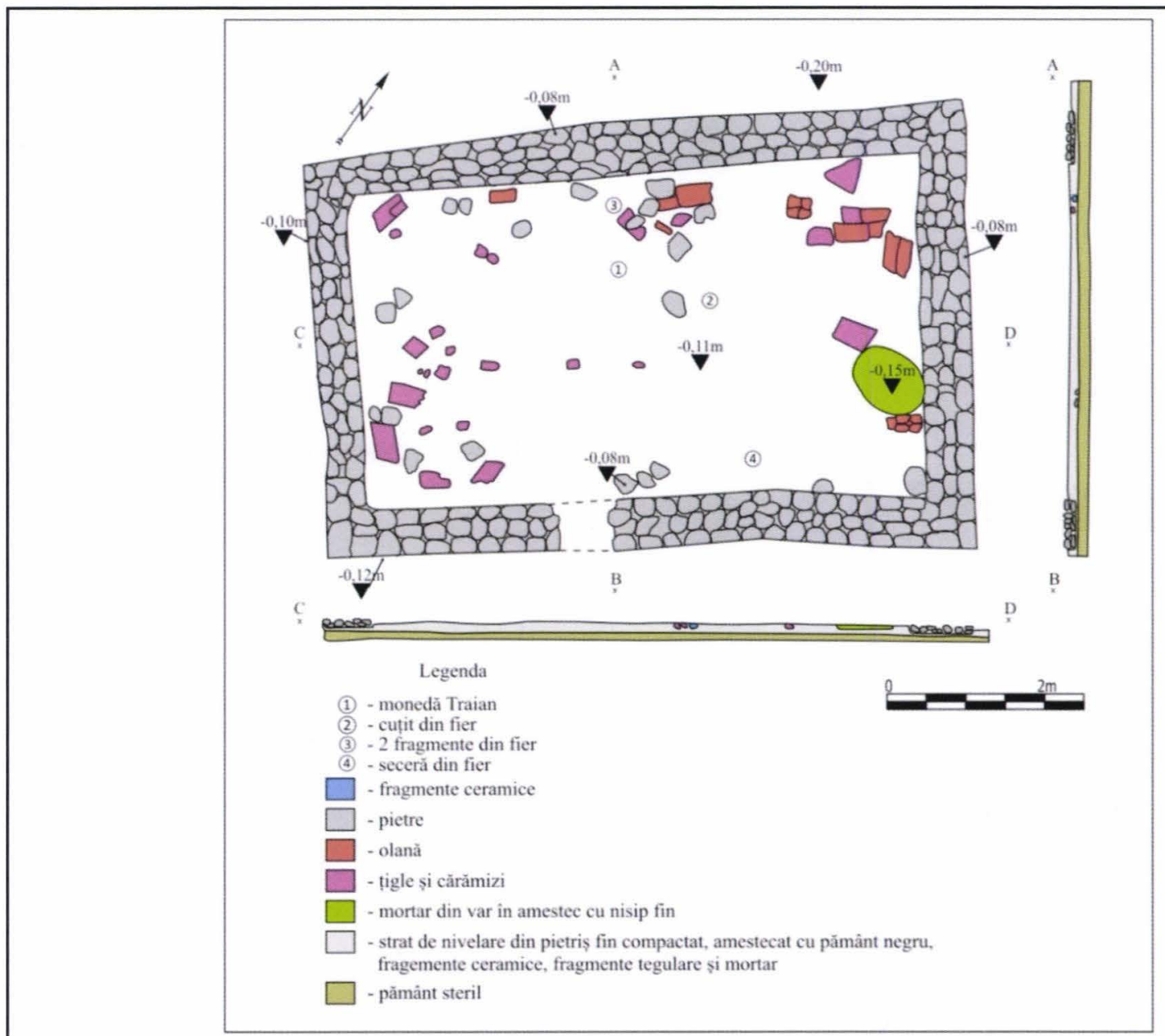

1.

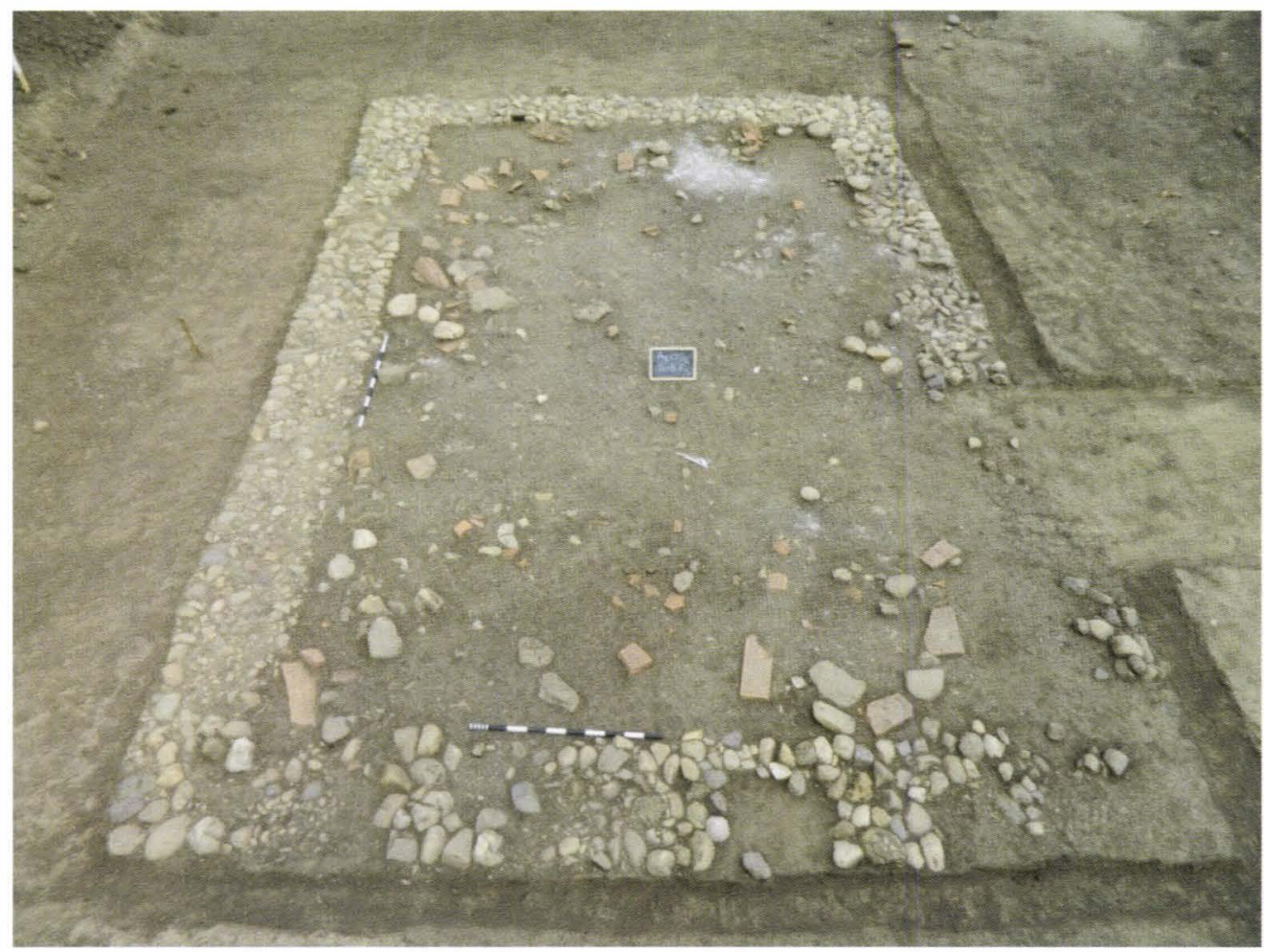

2.

Edificiul nr. 3: 1. Plan general; 2. Vedere generală dinspre vest 

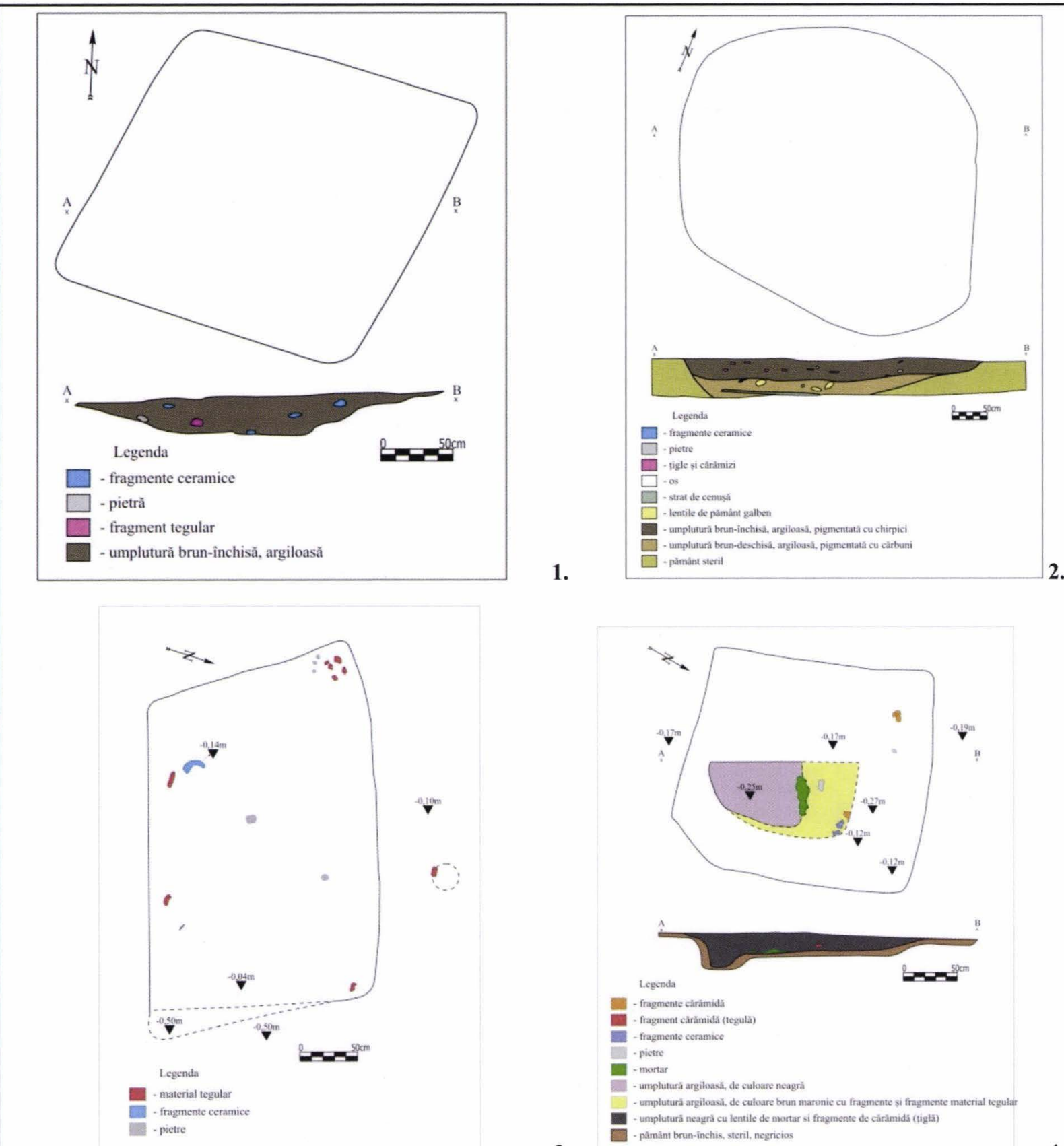

1.

2.

3.

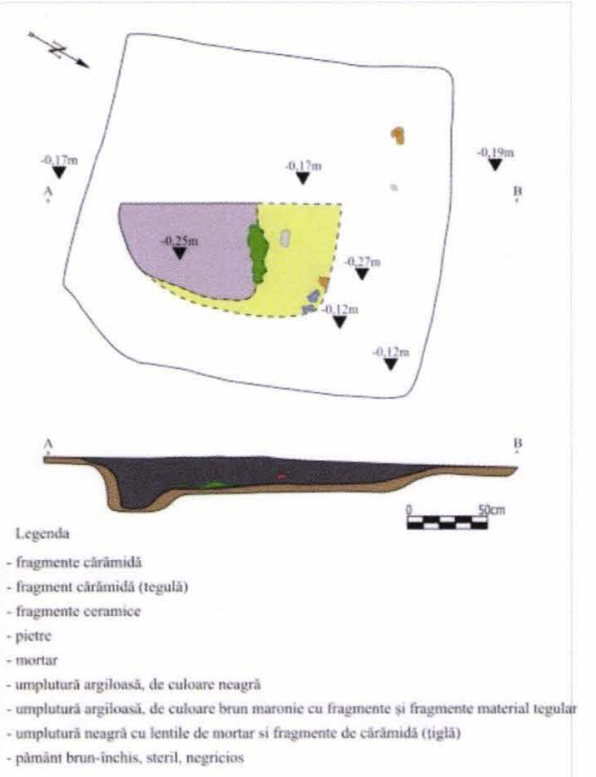

4.

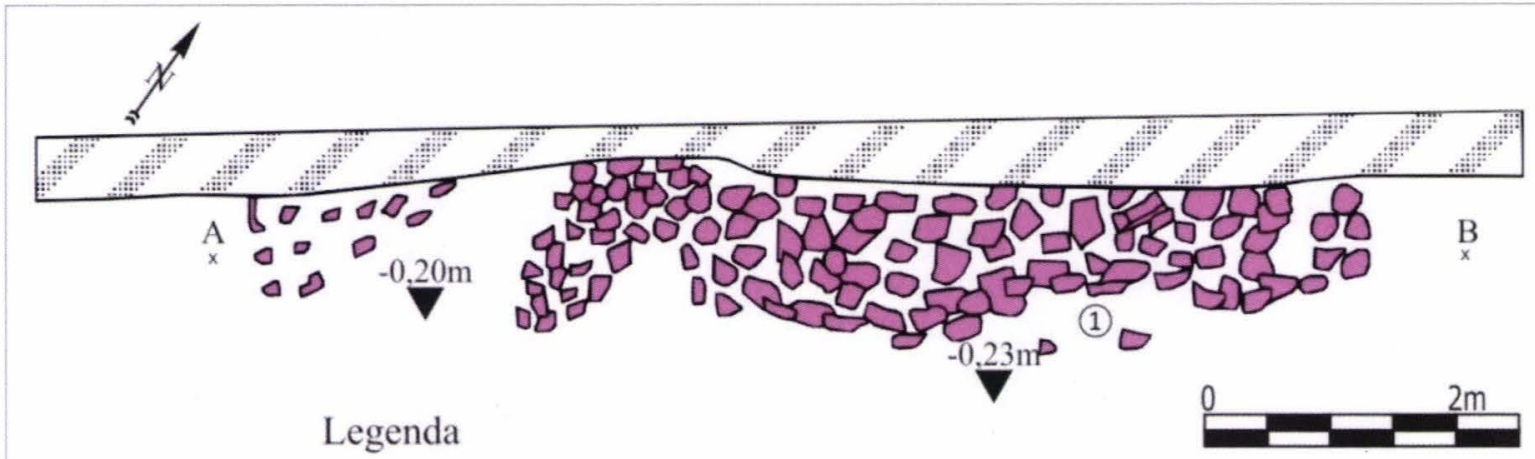

(1) - piesă din bronz

- material tegular

5.

1. Complexul 22, plan și secțiune transversală; 2. Complexul 24, plan și secțiune transversală; 3. Complexul 10, plan; 4. Complexul 4, plan și secțiune transversală; 5. Edificiul nr. 5, planul zonei investigate 


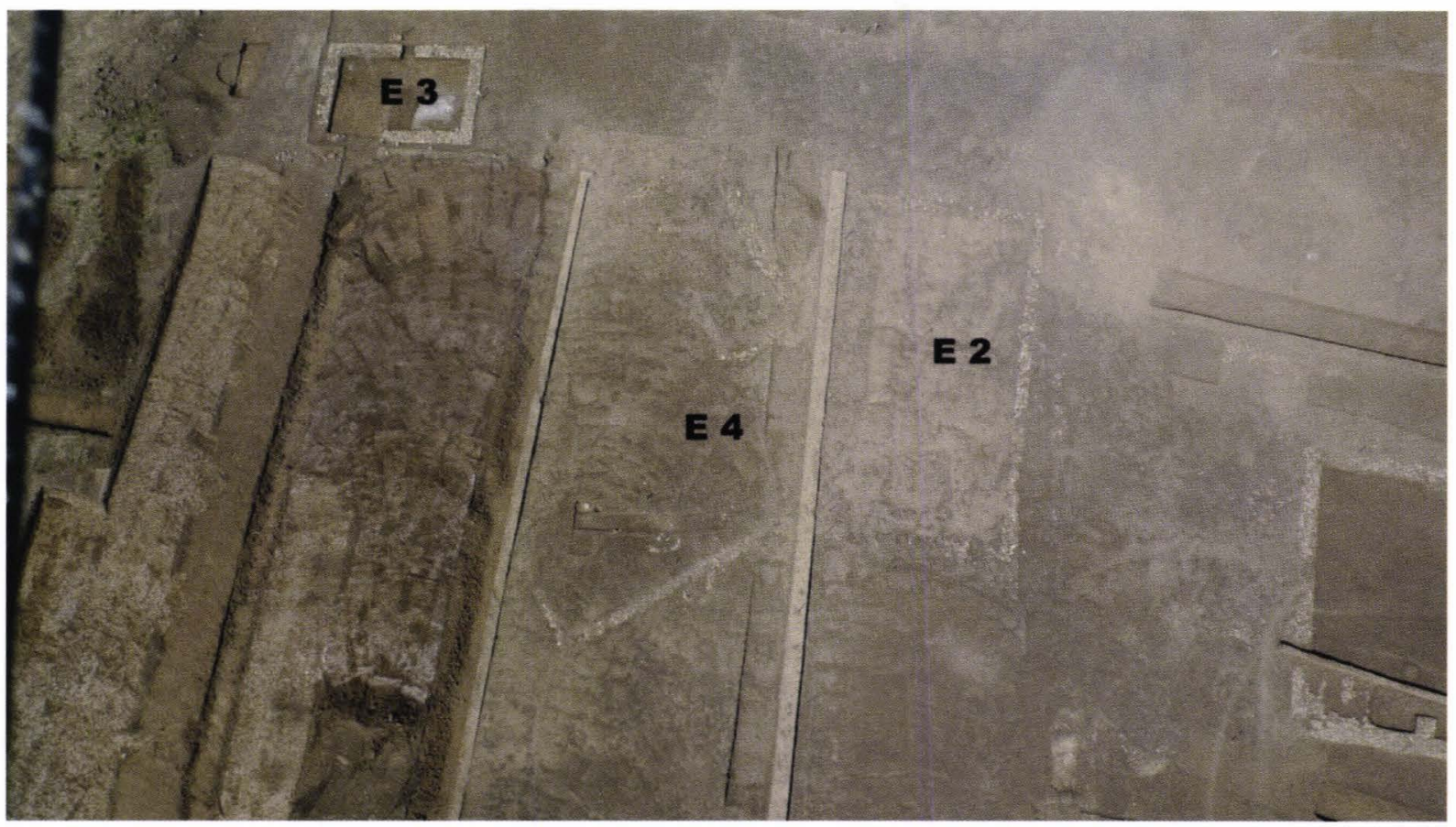

1.

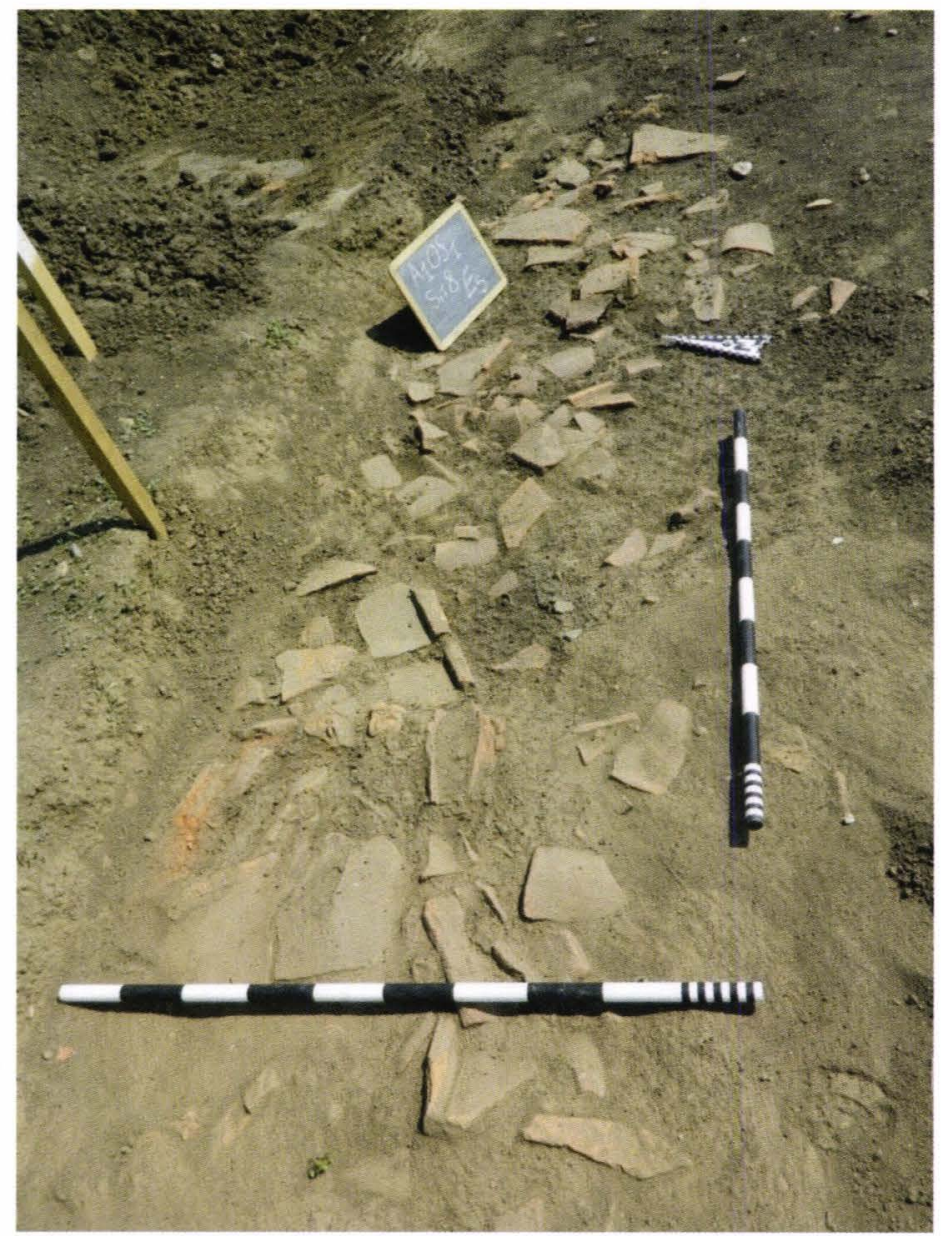

2.

1. Edificiul nr. 2, Edificiul nr. 3, Edificiul nr. 4, vedere aeriană; 2. Detaliu cu nivelul de dărâmătură corespunzător Edificiului nr. 5 

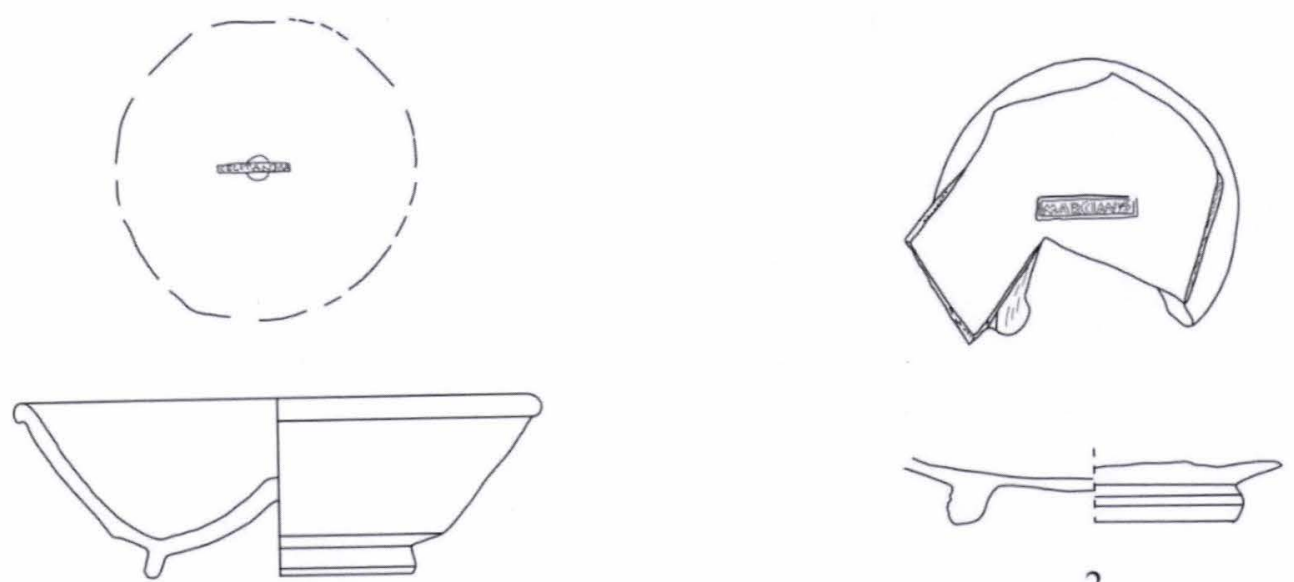

1.

2.
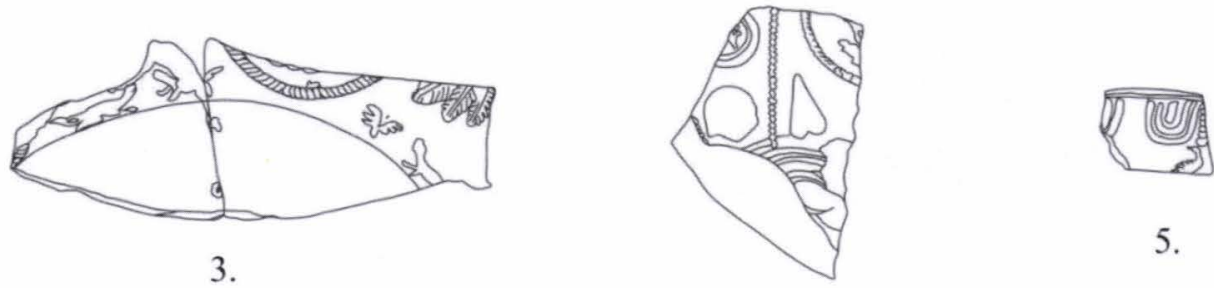

3.

4.

5.
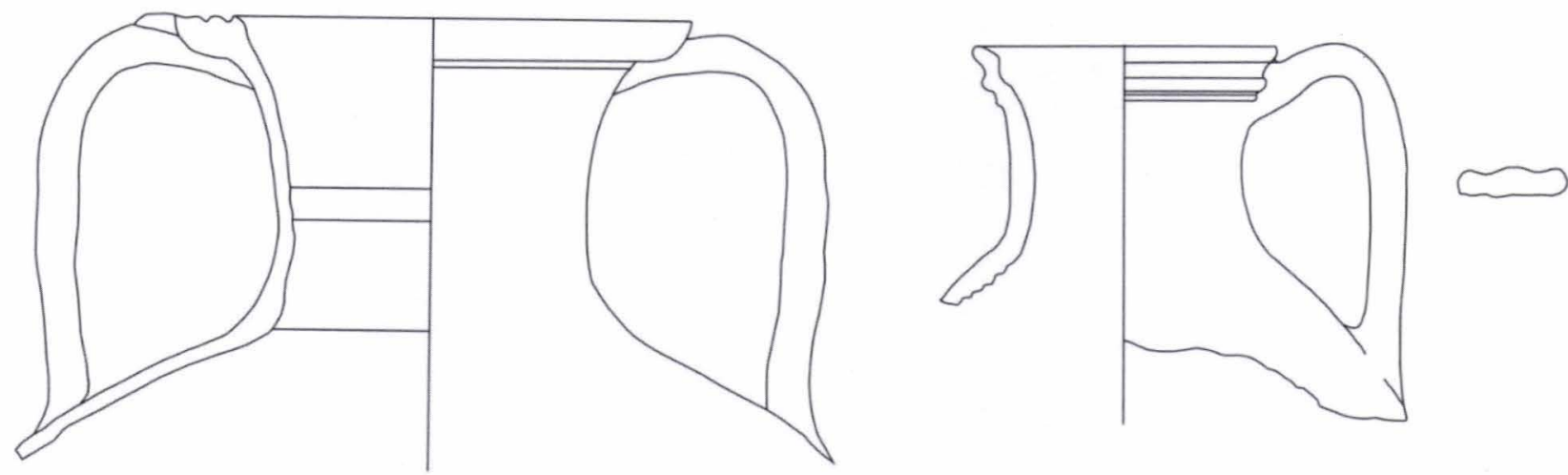

6.

7.

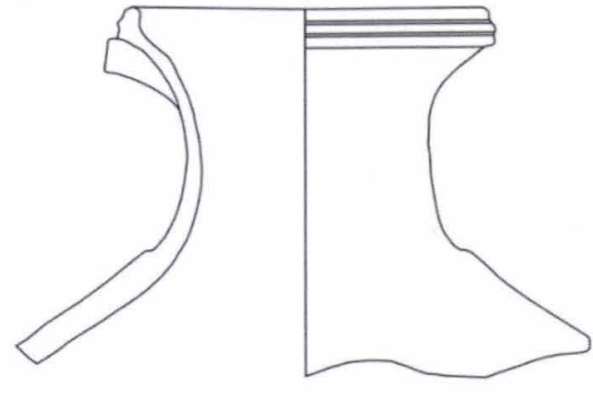

8.

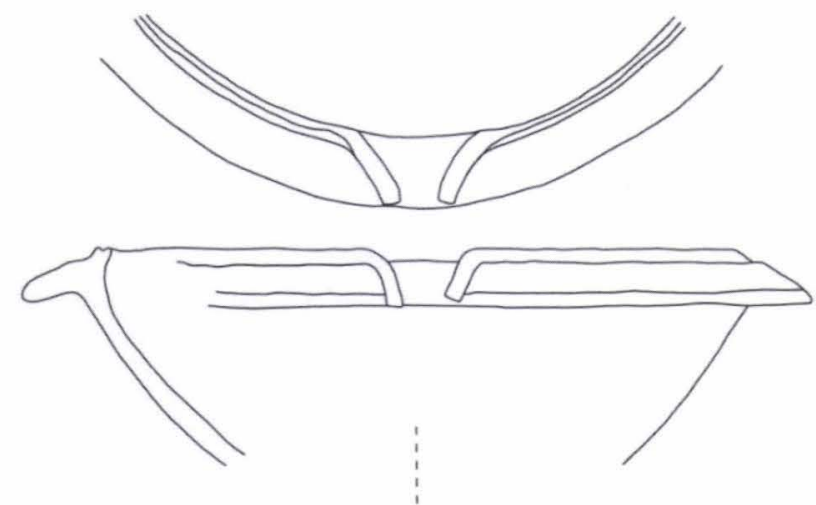

9.

Material arheologic din situl Tărtăria II (nr. cat. 1-9) 


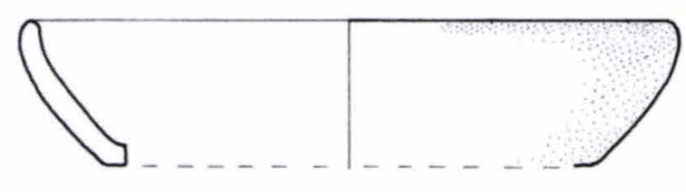

10.

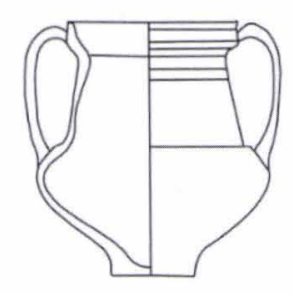

12.
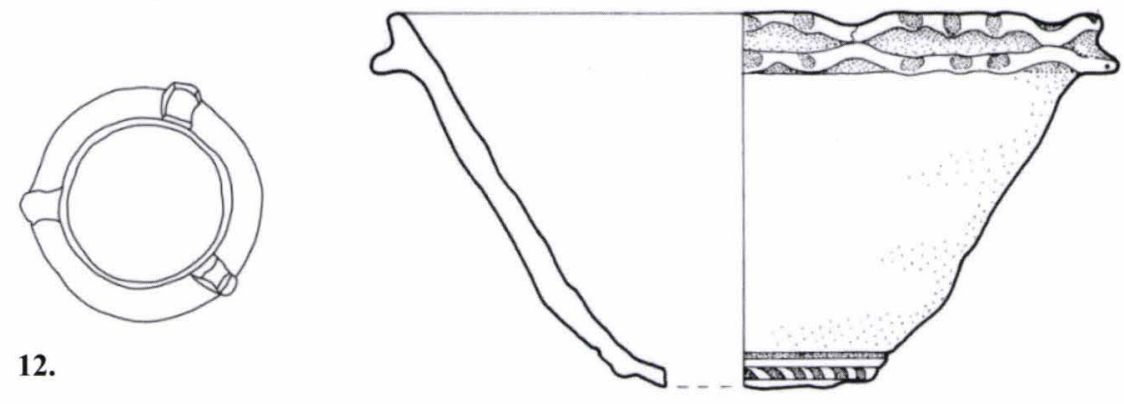

14.
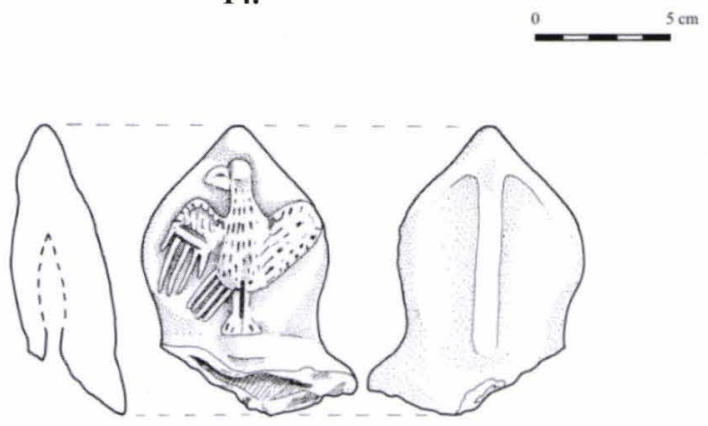

${ }^{0}-^{3 \mathrm{~cm}}$

16.

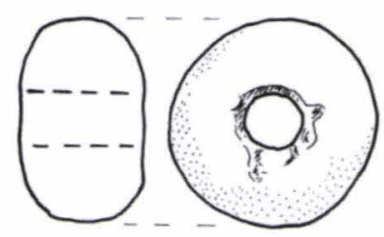

18.

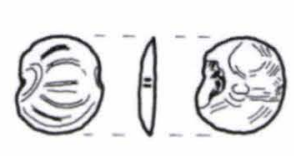

19.

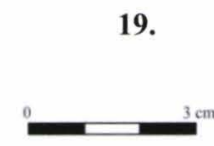

13.

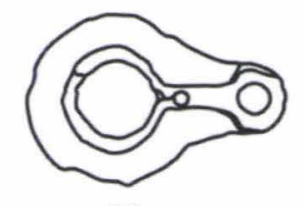

15.

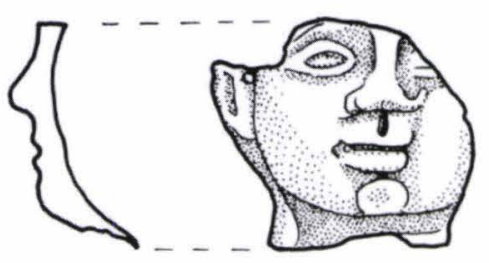

17.

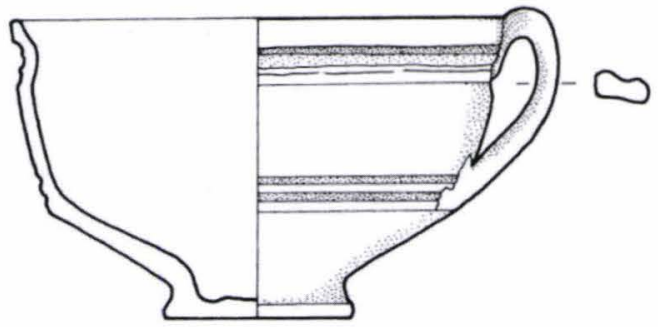

11.
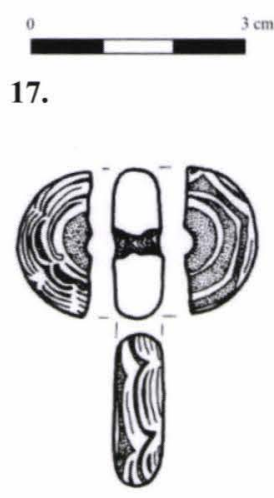

20.

Material arheologic din situl Tărtăria II (nr. cat. 10-20) 


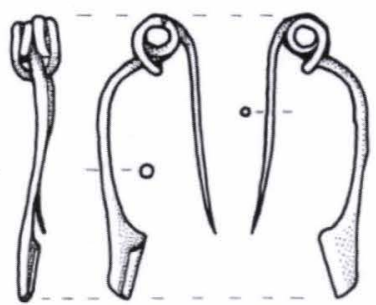

21.

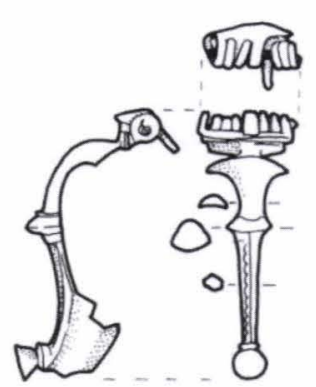

24.

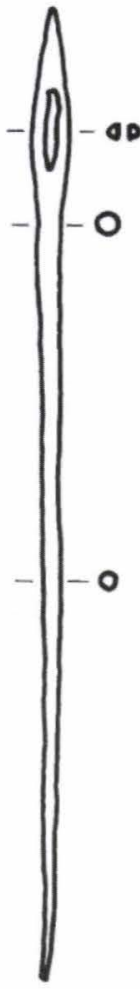

28.

29.

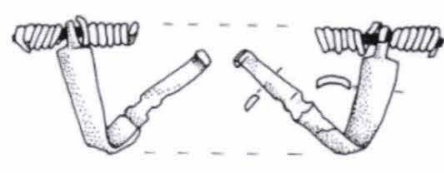

22.

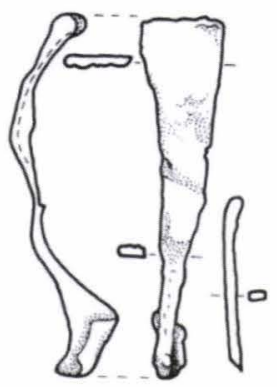

25.
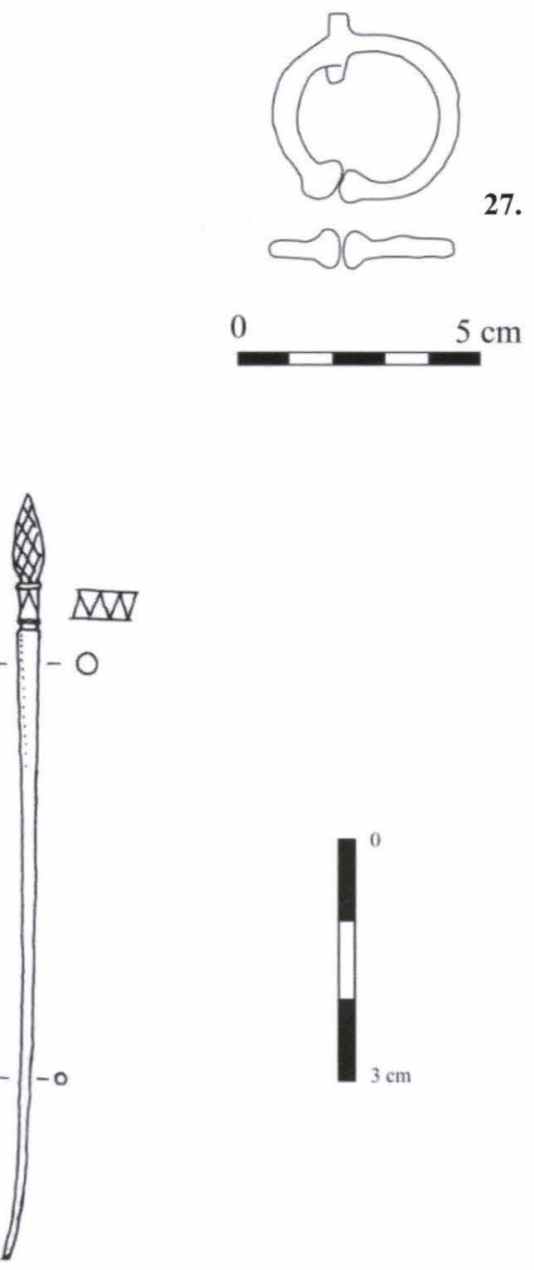

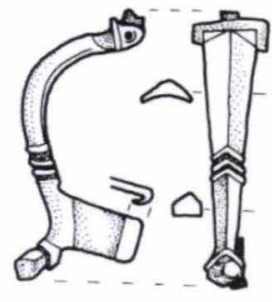

23.

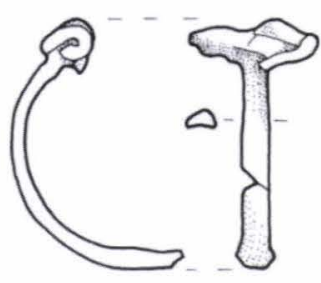

26.

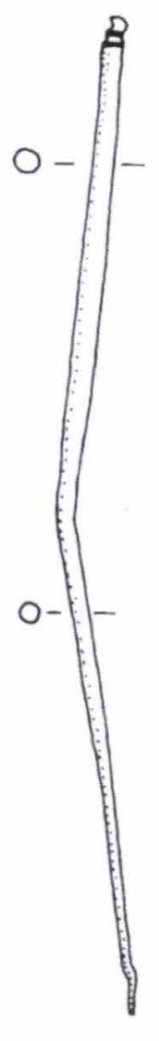

31.

Material arheologic din situl Tărtăria II (nr. cat. 21-31) 


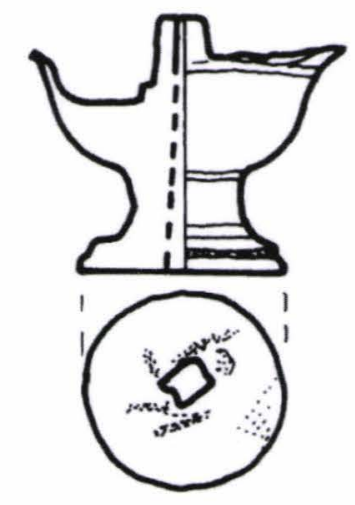

32.

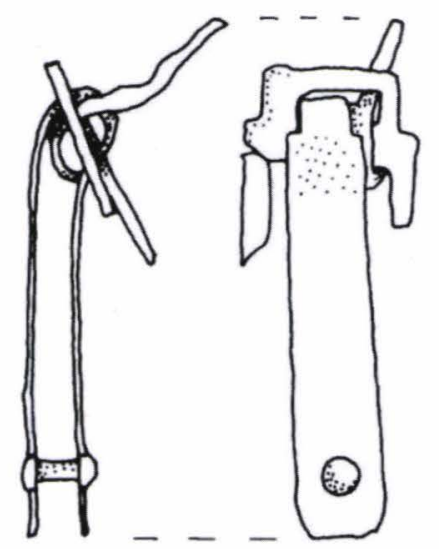

33.

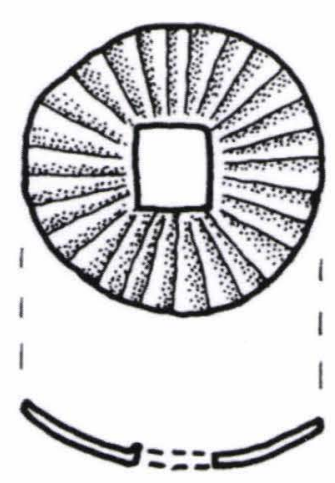

34.

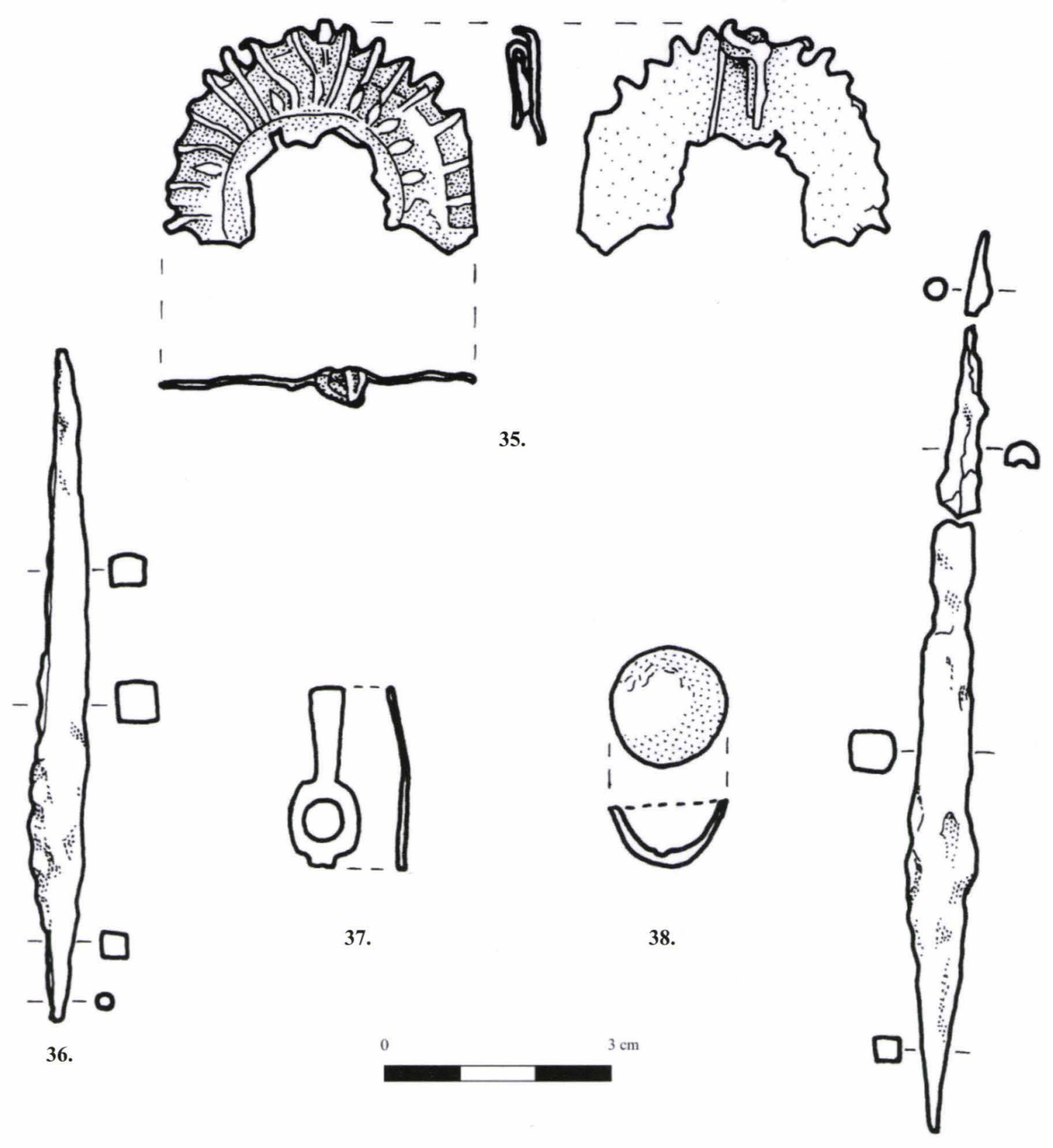

39.

Material arheologic din situl Tărtăria II (nr. cat. 32-39) 


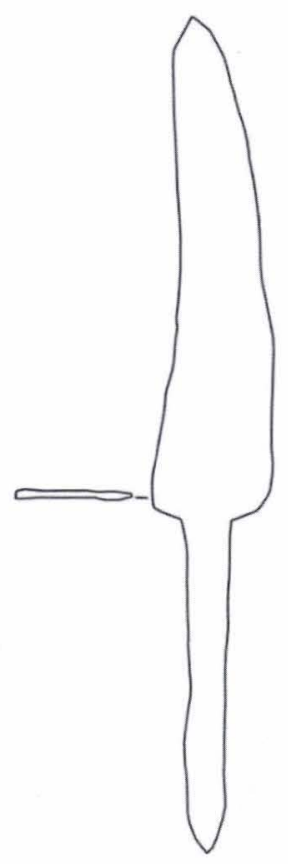

40.

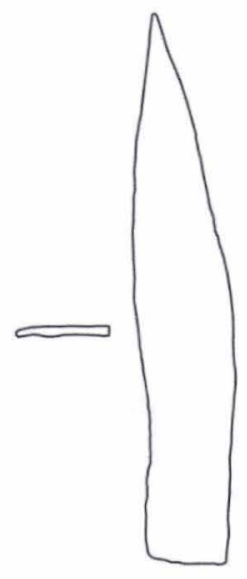

41.
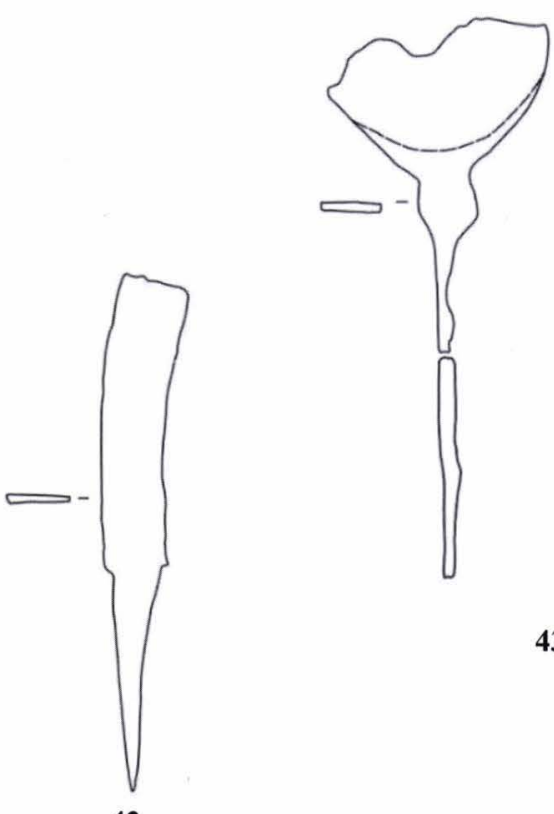

43.

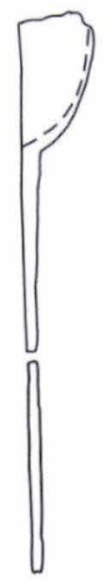

42.

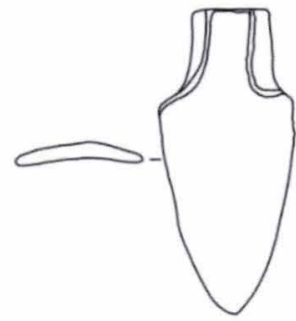

44.

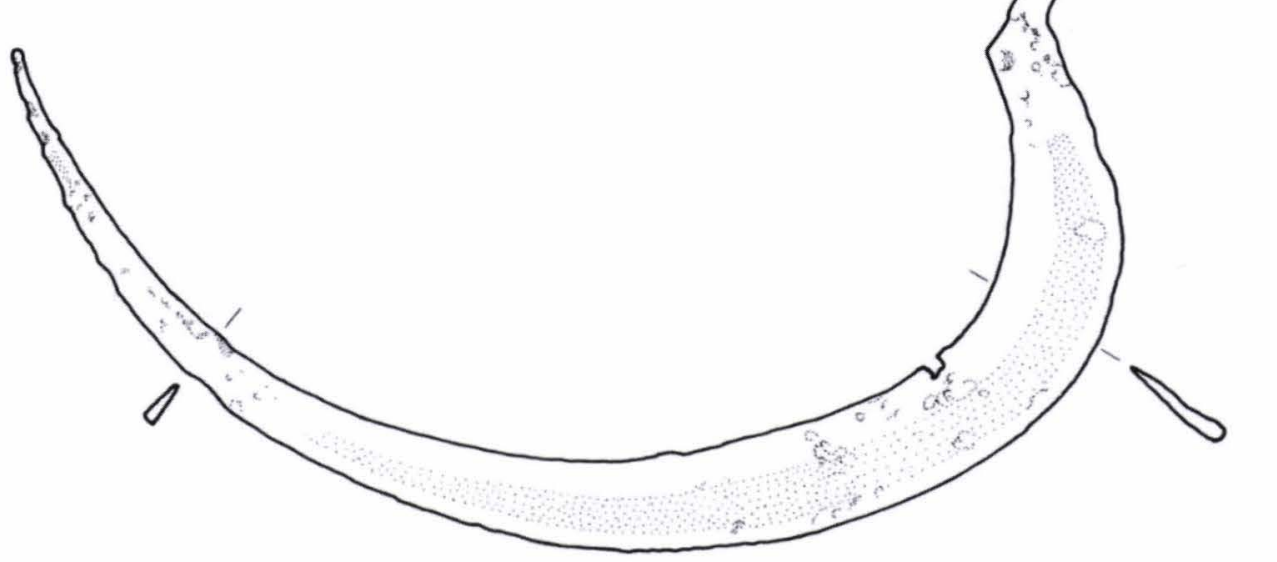

45.

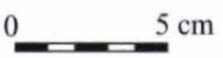

Material arheologic din situl Tărtăria II (nr. cat. 40-45)

\section{PI. XVIII}




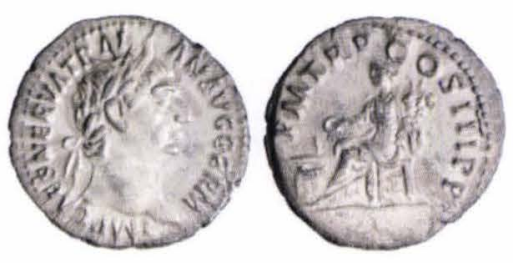

46.

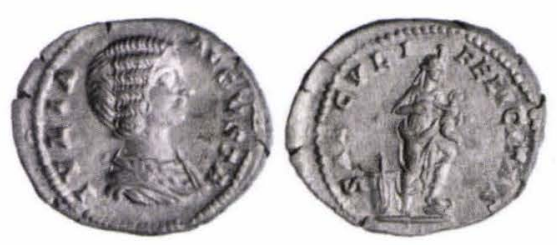

47.

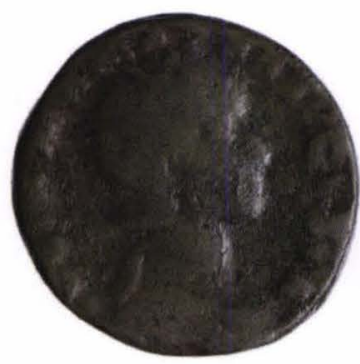

48.
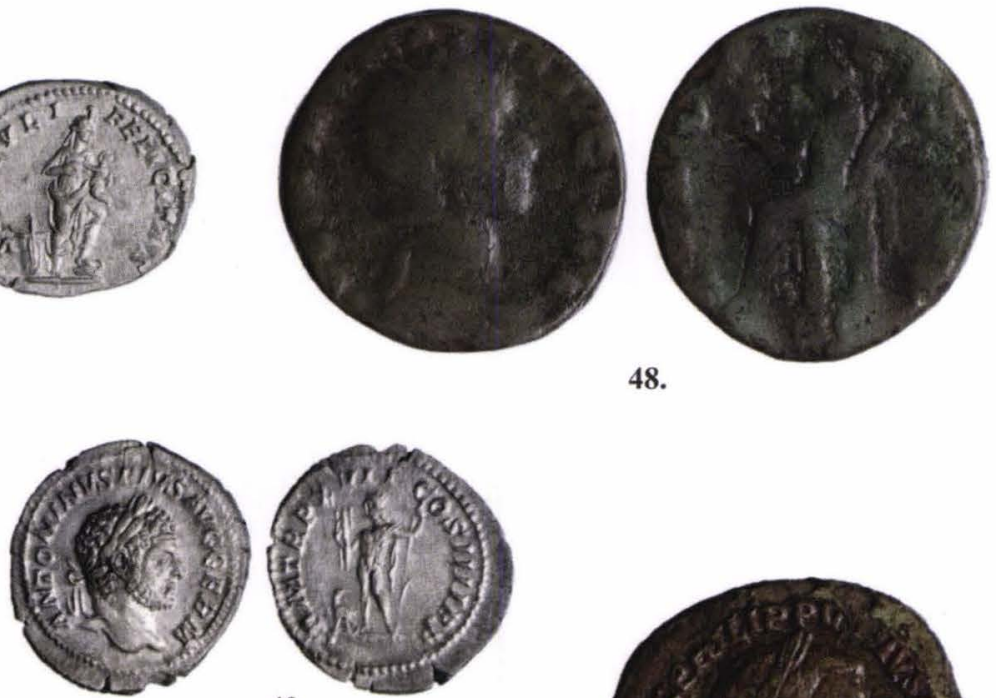

49.

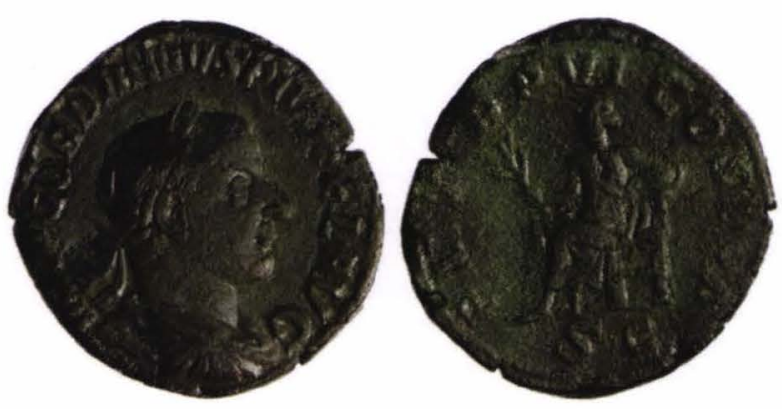

50.
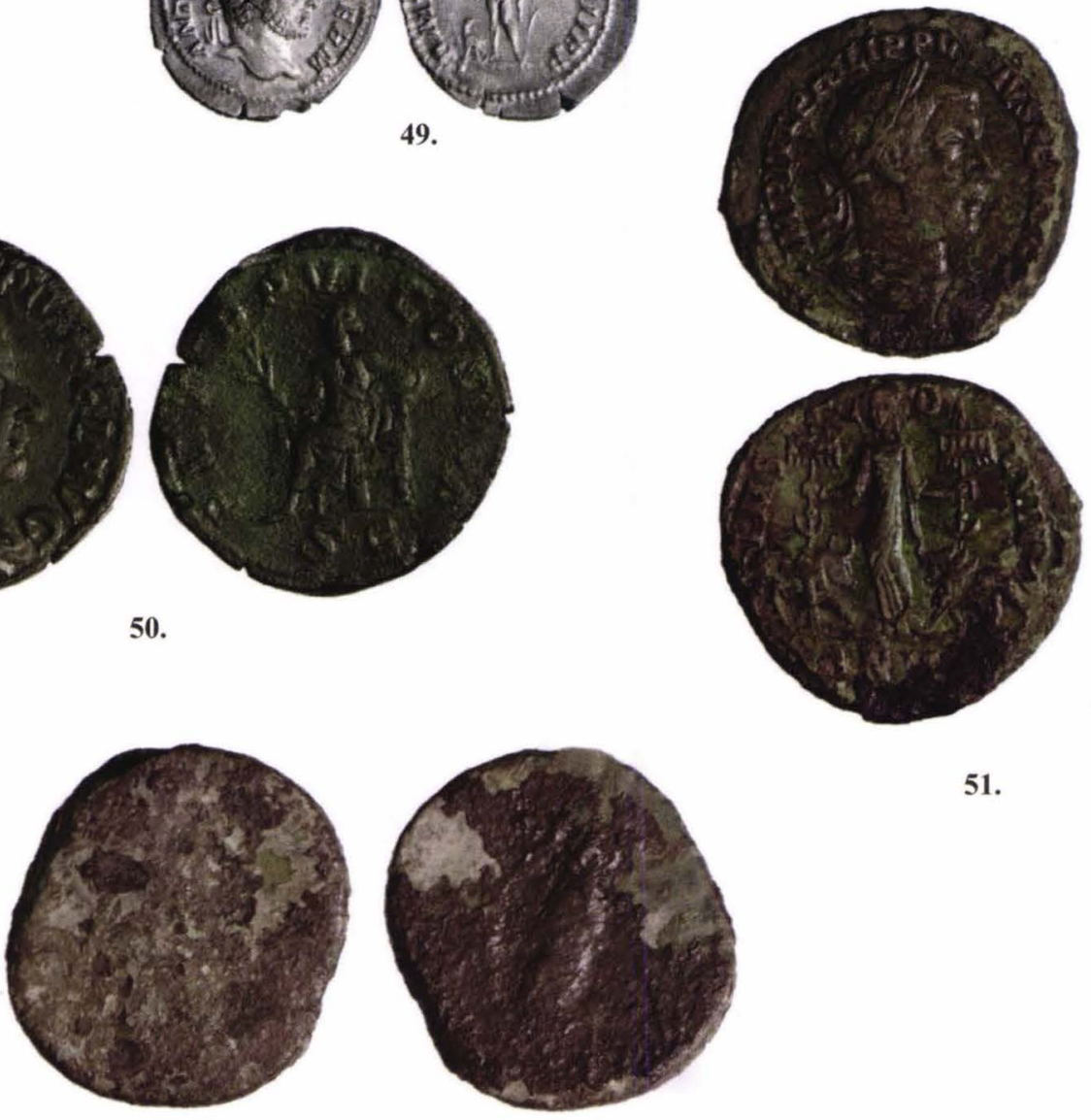

51.

52.

Material arheologic din situl Tărtăria II (nr. cat. 46-52) 


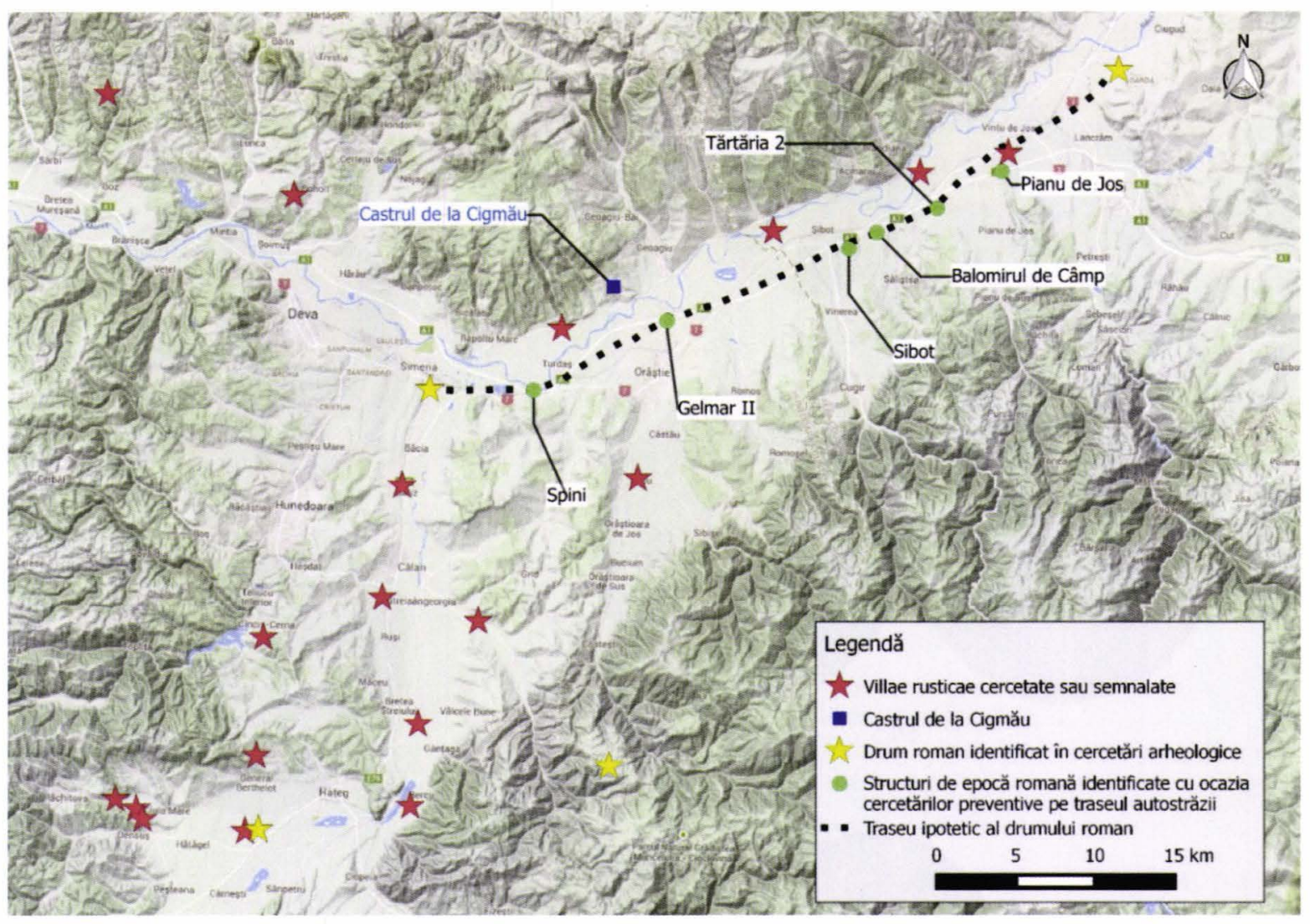

1. Structuri din epoca romană pe Valea Mureșului mijlociu (Sectorul Vințu de Jos - Simeria) Propunere pentru traseul drumului roman din stânga Mureșului. 